University of Denver

Digital Commons @ DU

$1-1-2018$

\title{
An Investigation of the Performance of Urban Rail Transit Systems on the Corridor Level: A Comparative Analysis in the American West
}

Daniel Zimny-Schmitt

University of Denver

Follow this and additional works at: https://digitalcommons.du.edu/etd

Part of the Human Geography Commons, Transportation Commons, and the Urban Studies and Planning Commons

\section{Recommended Citation}

Zimny-Schmitt, Daniel, "An Investigation of the Performance of Urban Rail Transit Systems on the Corridor Level: A Comparative Analysis in the American West" (2018). Electronic Theses and Dissertations. 1447. https://digitalcommons.du.edu/etd/1447

This Thesis is brought to you for free and open access by the Graduate Studies at Digital Commons @ DU. It has been accepted for inclusion in Electronic Theses and Dissertations by an authorized administrator of Digital Commons@DU. For more information, please contact jennifer.cox@du.edu,dig-commons@du.edu. 
An Investigation of the Performance of Urban Rail Transit Systems on the Corridor Level: A Comparative Analysis in the American West

\author{
A Thesis \\ Presented to \\ the Faculty of Natural Sciences and Mathematics \\ University of Denver \\ In Partial Fulfillment \\ of the Requirements for the Degree \\ Master of Arts \\ by \\ Daniel Zimny-Schmitt \\ June 2018 \\ Advisor: Andrew Goetz
}


Author: Daniel Zimny-Schmitt

Title: An Investigation of the Performance of Urban Rail Transit Systems on the Corridor Level: A Comparative Analysis in the American West

Advisor: Andrew Goetz

Degree Date: June 2018

\begin{abstract}
Since the 1980s, significant investments have been made in urban rail transit across the United States, particularly using light rail technology. Most of these light rail systems have been built in Sunbelt cities which no longer had legacy rail systems. As a result, they were constructed using a building blocks approach, being funded corridor by corridor. Most research, however, on urban rail performance has taken place at the system-wide level, leaving a significant gap at the level of the transit corridor. This research examined nineteen urban rail corridors in Denver, Salt Lake City, and Portland. A performance score was constructed for each corridor based upon ridership per mile, ridership growth, capital costs, and the cost of ongoing operations. These scores were then compared with a constructed profile of each corridor studied, which included aspects including but not limited to population and job density, median income, park and ride spaces, bus connections available, walkability, and headways between trains. Corridors in each city ranked high and low, with no city emerging as a clear frontrunner. Headways, population density, and percentage renter occupied housing units were found to have a statistically significant relationship with high corridor performance, largely in line with previous studies. Qualitative data gathered from this research suggest that partnerships with municipalities, communities, and businesses also played a crucial role in the development of successful urban rail corridors.
\end{abstract}




\section{ACKNOWLEDGEMENTS}

I would like to thank my thesis committee, Dr. Andrew Goetz, Dr. Eric

Boschmann, and Dr. Juan Carlos Lopez at the University of Denver for their guidance in completing this thesis. Special thanks to my direct advisor Dr. Goetz for challenging me to think about multiple dimensions of performance and a thorough list of factors which could be influencing it.

In addition, I would like to thank Eric Miller and Bill Van Meter at RTD Denver, Pete Baumgart, Mike Christensen, Auty Dahlquist, and David Steadman at Utah Transit Authority, and Daniel Maguire and Bryan Rose at TriMet for their help in compiling the ridership and scheduling information at each of their respective agencies. This research would not have been possible without their help in accessing and interpreting this information. Finally, I would like to thank Dr. Jing Li at the University of Denver for her help in using Network Analyst in ArcMap to create network distance buffers. 


\section{TABLE OF CONTENTS}

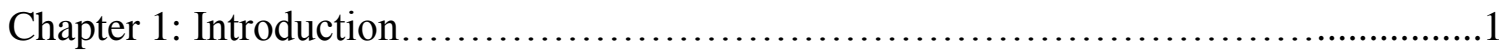

Chapter 2: Literature Review...........................................................

Introduction to the Effects of Urban Rail Transit.............................6

History of Urban Rail Transit Development in the US......................... 8

Measures for System Performance..........................................

Past Studies of System Performance..........................................12

Known Factors in Successful Rail Transit Systems............................16

Chapter 3: History of New Starts and Light Rail in Study Cities.........................18

FTA New Starts Program.................................................. 18

Background of Light Rail in Denver........................................... 21

Background of Light Rail in Salt Lake City.......................................25

Background of Light Rail in Portland........................................29

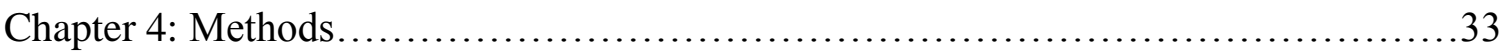

Study Site Selection................................................................ 33

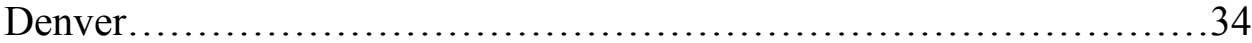

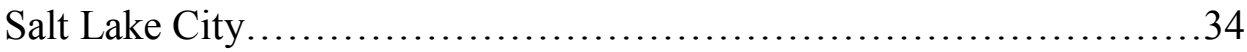

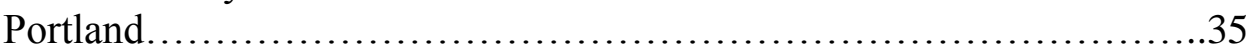

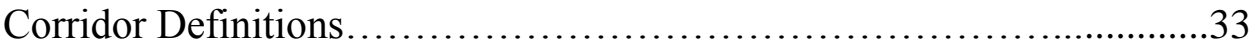

Ridership and Financial Forecasting..........................................

Calculating Ridership.................................................. 38

Calculating Capital Costs........................................................ 40

Calculating Operating Costs....................................................41

Performance Score......................................................... 43

Neighborhood Factors.................................................. 44

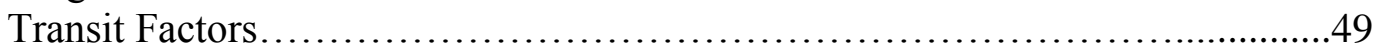

Explaining Performance................................................. 51

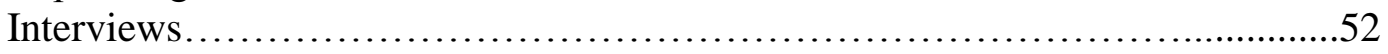

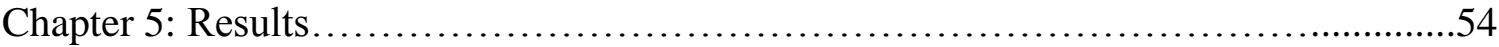

Forecast and Actual.......................................................... 54

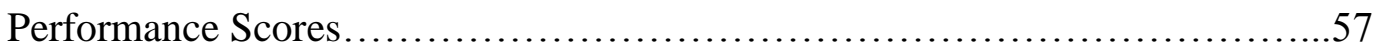

Performance and Corridor Characteristics...................................67

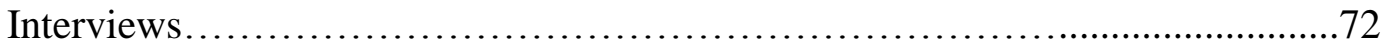

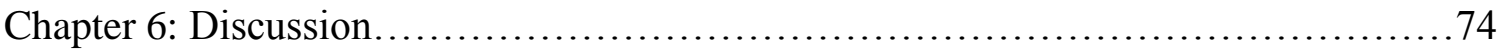

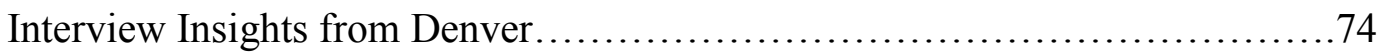

Interview Insights from Salt Lake City ......................................76 
Interview Insights from Portland......................................... 79

Major Themes........................................................ 81

Research Context.......................................................83

Chapter 7: Conclusion....................................................... 88

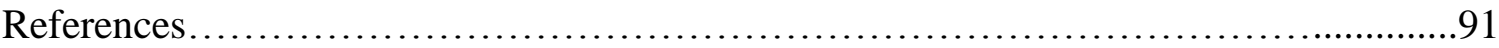

Appendices................................................................ 102

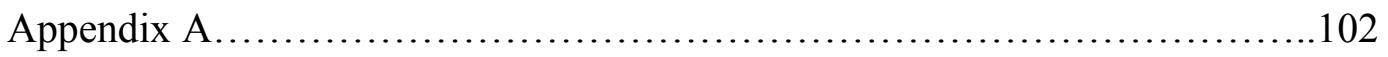

Appendix B........................................................... 107

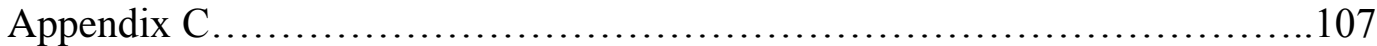

Appendix D......................................................116 


\section{LIST OF TABLES}

Chapter 2: Literature Review

Table 2.1: Previous Research.................................................15

Chapter 4: Methods

Table 4.1: Study Sites................................................... 33

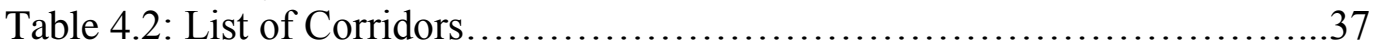

Table 4.3: Performance Score Inputs and Weightings............................44

Table 4.4: Corridor Characteristics..........................................51

Chapter 5: Results

Table 5.1: Forecast and Actual...............................................56

Table 5.2: Ridership by Corridor.........................................58

Table 5.3: Capital Cost by Corridor..........................................60

Table 5.4: Operating Cost by Corridor......................................62

Table 5.5: Corridors Ranked by Performance.................................65

Table 5.6: Performance and Corridor Characteristics.............................68

Table 5.7: Regression Analysis Results.............................................71

Table 5.8: Variability Between Cities..................................... 72 


\section{LIST OF FIGURES}

Chapter 3: History of New Starts and Light Rail in Study Cities

Figure 3.1: Map of Denver light rail system.................................24

Figure 3.2: Map of Salt Lake City light rail system..........................28

Figure 3.3: Map of Portland light rail system...................................33

Chapter 4: Methods

Figure 4.1: Map of Denver Block Groups...................................46

Figure 4.2: Map of Salt Lake City Block Groups...............................47

Figure 4.3: Map of Portland Block Groups...................................48 


\section{CHAPTER 1: INTRODUCTION}

In the past few decades, new passenger rail transit systems have been developed in US metro areas, especially in cities in the South and West which completely scrapped their rail transit and streetcar systems in the postwar period. These projects have contended with a mix of political support and opposition, with much of the opposition stemming from the projects' considerable costs. Assessing whether these publicly funded investments have paid off as measured by ridership and financial performance needs to be quantified if future rail development is to receive the needed political support. However, evaluating the success of urban rail investments is a difficult task. There are multiple dimensions that can be considered, from ridership figures and operating subsidies to new transit oriented development and quality of life measures. While some of these data may be available from transit agencies themselves, some may need to be obtained from third parties or be more deeply investigated.

Most of the urban rail transit systems that came into operation in the 1980s, 1990s, and 2000s were funded and built in a piecemeal, corridor by corridor approach. Over time, these corridors grew into the integrated systems that exist today in multiple cities across the Sunbelt. However, after each corridor was built, little was done to evaluate its performance individually, since the ridership and financial statistics for each corridor were rolled into the data for the transit agency as a whole. Thus, in evaluating 
the performance of urban rail systems, the corridor level has garnered less attention than evaluations made at the system-wide level or individual station level. Given the crucial role the choice of corridor plays in the funding and construction of these projects, assessing the performance of these systems by corridor is an important yet understudied topic. This study provides a comprehensive evaluation of the performance of corridors individually in hopes of providing a better understanding how future investments in urban rail corridors should be made.

Beyond simply evaluating the performance of these corridors, determining what factors may contribute to their relative successes is an equally important task. The characteristics of the neighborhoods and business districts through which these corridors pass may be significant factors in determining their performance. The socioeconomic profile, population density, employment density, and walkability within the corridor are some of these characteristics. Other characteristics over which the transit agency has more direct control may also impact performance. These can include the headways between trains, the number of park and ride spaces available, and number of bus connections.

Evaluating ridership and financial information in conjunction with corridor characteristics to evaluate performance gives transit agencies and policymakers a better understanding of rail transit performance in their jurisdictions, and a more in depth view of how public funds were utilized. Furthermore, it advances our understanding of the relationship between the performance of rail transit systems and the areas which they serve. By looking at corridor characteristics like median income and population density, 
correlations between performance measures and these characteristics will yield insight into factors affecting ridership within rail corridors, an already existing area of research. Findings will also contribute to the growing body of literature examining the relationship between land use and transit, transit oriented development, and job accessibility through transit. Research on the effectiveness of transit systems has taken on both qualitative and quantitative forms in recent decades. This study integrates both quantitative performance data and qualitative interviews to provide a broader understanding of system performance. Investigating rail transit investments more holistically yields new insights into what characteristics successful corridors and systems share.

In this study, I develop a strategy by which these rail transit corridors can be systematically evaluated for their performance based on ridership and financial figures. A comprehensive study focusing on ridership and financial performance, bolstered by a profile of the characteristics of each corridor, yields significant insight on what corridor characteristics are necessary to make these systems successful. While I will only investigate three systems, the methodology employed can serve as a blueprint for replication on a larger scale. Because of its integrative approach, this will allow for more systematic evaluations of how urban rail transit systems are performing in other cities nationwide. My methodology could also be applied to other public transit systems in the US that currently do not have rail corridors, such as bus rapid transit routes that utilize fixed routes with limited stops. This substantially increases the number of corridors that can be evaluated for effectiveness. Given the current political climate and competition for 
infrastructure spending, developing an effective evaluation method of current rail transit systems is of great importance.

Chapter 2 provides a review of the relevant existing literature on this topic. This literature comes from both the academic transportation geography realm and the government practitioner realm, since urban rail transit is often studied by both. Most of the academic literature focuses more on the effects rail transit can have on the places it serves, from transit oriented development to job accessibility, while the majority of the practitioner literature focuses on details related to best practices for enhancing performance at the transit agency level. Both are necessary bodies of research in order to holistically evaluate the successes and shortcomings of existing urban rail transit systems.

Chapter 3 presents a history of the Federal Transit Administration's New Starts program, which has been the primary source of public funds driving the current wave of light rail transit development in the Sunbelt and in the three cities in this study. It also discusses the individual histories of light rail development in Denver, Salt Lake City, and Portland, providing important background information on the corridors evaluated in this study.

Chapter 4 dives into the methods used to carry out the study, from how quantitative data were gathered to how the qualitative interviews were conducted. Specifics of how ridership and financial figures were interpreted, how the performance score for each corridor was constructed, and how corridor characteristics data were 
collected are all discussed. Finally, the details on how the performance score was correlated to the corridor characteristics is discussed.

Chapter 5 presents the results of the study, both in terms of ranking each of the nineteen corridors and presenting the significant correlations that exist between performance and corridor characteristics. A number of tables and figures are included in this chapter to summarize these results. An overview of how the quantitative results compare to information gathered in the interviews concludes the chapter.

Chapter 6 presents insights garnered from the interviews in each city, and reconciles the similarities and differences generated by the quantitative and qualitative portions of the study. What the results mean in terms of informing future rail transit investments is also considered, concluding with suggestions for future research topics that can further test whether trends observed hold true on a larger scale.

Chapter 7 provides an overview of the lessons learned in the study, briefly reviewing the construction of a performance score and correlation analysis, before tying in the findings from the qualitative interviews. 


\section{CHAPTER 2: LITERATURE REVIEW}

Evaluating the performance of urban rail transit systems falls in the hands of both academic researchers and government practitioners working for individual transit agencies, local governments, or larger agencies like the Federal Transit Administration (FTA). Thus, a review of the existing relevant literature from both of these sources is necessary. As this study aims to evaluate both performance and factors potentially influencing performance, both will be considered in this review of literature.

\subsection{Introduction to Effects of Urban Rail Transit}

Transportation infrastructure plays a well-recognized role in the economic performance of regions and cities. Particularly, rail transit plays a crucial role in providing workers access to jobs, revitalizing central business districts, enhancing competitiveness, and generating new transit oriented development (Eddington, 2006; Docherty et al. 2009; Holvad and Leleur, 2015; Knowles and Ferbrache, 2015). Urban rail systems have a multitude of economic effects on the cities they serve. For one, rail transit is an important component of cities competing globally, as they provide a necessary mobility link between home and work and between airport and business district (Niedzielski and Malecki, 2012). The infrastructure also creates connectivity between employees and businesses (Docherty et al. 2009), and has been found to generate 
significant job accessibility for all workers from low to high income earners, leading to new job creation (Fan, Guthrie and Levinson, 2012).

Rail transit has also been shown to increase residential and commercial property values near rail stations, in locations ranging from San Diego and Santa Clara to Dallas and Buffalo (Al-Mosaind et al. 1993; Dueker \& Bianco, 1999; Weinstein and Clowner, 1999; Cervero and Duncan, 2002; Cervero, 2003; Hess and Almeida, 2006). Knapp, Ding, and Hopkins (2001) found that plans to invest in rail transportation infrastructure alone can have a positive effect on property values in areas around the proposed stations, and promote higher density development. However, a comparative analysis examining multiple systems in California suggests a more nuanced take on this question may be more appropriate. Residential property values were found to increase for some systems with high service levels, namely Bay Area Rapid Transit (BART) and the San Diego Trolley, but not around other systems, like the Sacramento and San Jose light rail. Commercial property values were also not found to have any relationship with proximity to rail transit stations (Landis et al. 1995).

Urban rail transit has spurred transit-oriented development (TOD), which encapsulates the process of focusing the development of housing, employment, places of activity, and public services around rail stations to create a form of higher urban density (Calthrorpe, 1993; Knowles; 2012). Within TOD zones, an influx of new investments has increased residential and commercial space near rail transit and spurred job creation (Ratner and Goetz, 2013; Carroll, Carlyle and Seman, 2015). 
Understanding how access to rail transit impacts residents living close to stations has also been a major field of study, especially with regard to parking and vehicle miles traveled (VMT). Residents in TODs have been found to drive less and generate less demand for parking (Arrington and Sloop, 2009; Nasri and Zhang, 2014; Ewing et al. 2017). Even outside of TODs, parking demand in areas within a short walking distance to rail stations was found to be lower (Cervero, Adkins, and Sullivan, 2010). Indeed, built environments that are high in the so-called "D-variables" of density, land use diversity, and pedestrian oriented designs encourage non-auto travel (Cervero \& Kockelman, 1997). Later studies have expanded upon these original D-variables to include factors such as destination accessibility and distance to transit, while finding similar results (Ewing et al. 2017, Ewing and Cervero, 2017). However, determining causality between changes in travel behavior and the existence of rail transit often remains elusive, since it is nearly impossible to control for all of the variables that may influence travel decisions (Boarnet, 2017). Still, in some cases experimental design can be mimicked through the use of a control group in the case of a newly opened light rail line. Brown and Werner (2008) employed this design in a study around a new light rail station in Salt Lake City, and found residents in the area who were transit riders took fewer car rides, had lower rates of obesity, more attachment to place, and greater neighborhood satisfaction. In a similar vein, Ewing and Himidi (2014) found that after a light rail line was built in Portland, the resulting corridor had higher density, generated more household walking and transit trips, and experienced a slower rise in VMT per capita when compared to a nearby highway corridor. 


\subsection{History of Urban Rail Transit Development in the US}

Urban rail transit systems largely fell into disrepair and out of service in the postwar era, as suburban growth was led by the automobile. At its nadir in the 1950s, only five cities in the country had operating urban rail transit: New York, Boston, Philadelphia, Cleveland, and Chicago (Ratner, 2001). The Urban Mass Transportation Administration (UMTA) was established in 1964, and proved to be a turning point for rail transit in American cities by providing the capital assistance needed to help expand existing systems and build new ones. The early recipients of these funds used heavy rail technology to build out their systems; namely the BART in the Bay Area, the Metro in Washington, DC, and the Metropolitan Atlanta Rapid Transit Authority (MARTA) in Atlanta. These three systems first opened in the 1970s, and were following by other heavy rail transit systems in Miami and Baltimore. However, by the mid-1980s, the heavy rail phase of development was ending and giving way to light rail (Ratner, 2001). This shift toward light rail technology was less costly, less disruptive to the surrounding environment, and a better fit for lower density cities (Ratner, 2001).

This renewed investment in public transportation infrastructure resulted in a dozen new systems opening, as light rail systems were planned and developed in both Rustbelt and Sunbelt cities. In the 1980s alone, Baltimore, Miami, San Diego, Buffalo, Pittsburgh, Portland, Sacramento, and San Jose saw ribbon cuttings for new rail systems. The 1990s continued this trend, with Denver, Dallas, St. Louis, and Salt Lake City leading the way. The number of light rail projects has continued to grow, while enjoying 
significant public and political support in the past few decades as more have come online (Giuliano, 2004).

\subsection{Measures for System Performance}

Since these rail transit systems were constructed using public funds, periodic updates and performance reports were required by UMTA and its present-day successor, the FTA. The FTA maintains the National Transit Database (NTD), a national repository of data on the financial, operating, and asset conditions of transit systems in uniform categories under two major umbrellas. These umbrellas are service efficiency and service effectiveness, with the former primarily focusing on costs and the latter on passengers. The performance figures collected include measures such as operating expenses per vehicle revenue mile, operating expenses per passenger mile, farebox recovery ratio, and cost per passenger carried.

Measuring success solely through these figures, however, can be misleading, since success comes in many forms and is inherently hard to define. The point of view of the customer and community needs to be taken into account, as factors including but not limited to travel time, safety, traffic congestion, and air pollution are also important measures (Transit Cooperative Research Program Report 88, 2003). Research has also considered alternative methodologies for performance measurement and peer comparison for fixed route transit systems, and rail modes specifically. Real performance measures need to be compared to another meaningful measure, such as past performance, targeted performance, or fair peer comparisons to have real significance (TCRP Report 141, 
2010). As such, this study aims to integrate elements of all three when considering performance.

System performance is often measured against initial forecasts. Thus, having an understanding of the process behind generation of these forecasts is important. Early studies of forecasting leaned on professional judgments, preference surveys, and studies of potential transit riders (Pratt et al. 1977; Mayworm et al. 1980). This was replaced by four-step models with the component parts being trip generation, trip distribution, modal split, and traffic assignment (Dickey, 1983; Johnston, 2004). Additional forecasting steps were added to take station accessibility, urban design, density, and land use diversity into account (Cervero, 2006). These trip generation models are used to predict trips generated by a household or an attraction (Meyer and Miller, 2001), and are the models often used to make ridership forecasts in the first place by taking into account factors such as the population density and socioeconomic profile of a given area. In recent years, transit planners have increasingly turned toward simpler, faster, and more spatially detailed sketch planning or direct demand models for forecasting and rail transit boardings (Upchurch and Kuby, 2013). Activity-based models have also come into favor, as they integrate longer term mobility and lifestyle decisions, activity and travel scheduling decisions at more frequent intervals, and rescheduling decisions that occur in real time in response to conditions in the transportation system (Miller, 2017). However, the four-step Urban Transportation Model System remains the most common.

Ridership and financial forecasting remains far from a perfect science. Mackett (1998) found that forecasts are often wrong, and questions whether that fact really 
matters. A comprehensive study of 258 transportation infrastructure projects found overwhelming evidence that cost estimates were highly and systematically misleading (Flyvbjerg, Holm, and Buhl, 2002). Costs were found to be underestimated in 90 percent of projects, with rail projects displaying the highest gap between projections and final figures with an average underestimation of 44.7 percent. Furthermore, cost underestimation has not decreased over time (Flyvbjerg, Holm, and Buhl, 2002). However, a subsequent study indicated a marked improvement over time in forecasting transit ridership and costs (Lewis-Workman et al. 2008). Boyle (2006) found that roughly one third of transit agencies were satisfied with the reliability of ridership forecasts at the station level, one third of agencies were partly satisfied, and one third were dissatisfied with forecasting models. Twenty percent of agencies used regression, 51 percent used four-step models, and 80 percent used professional judgment and rules of thumb (Boyle, 2006). Clearly, ridership and cost estimates should not be relied on exclusively to measure performance because of their history, making past performance or peer comparisons important complementary measures.

\subsection{Past Studies of Rail Transit Performance}

A variety of studies have investigated whether rail transit systems have performed according to these initial forecasts and expectations as a way to measure the accountability of public expenditures. Some rail systems produce benefits that outweigh their investment costs while others do not, even though these realities are often obscured by the ideologies of the politicians or think tanks involved (Cervero and Guerra, 2011). Some studies highlight the ineffectiveness of transit (Cox, 2002; O’Toole, 2010), while 
others indicate its success (Litman, 2006; Litman, 2009). Recent research has found that just over half of 24 different rail systems studied in the US have net social benefits that outweigh their costs (Cervero and Guerra, 2011). However, different methodologies and ideologies used to measure performance have undoubtedly contributed to the mix of results in the literature.

Early studies from the 1990s examining the performance of rail transit systems often reached conclusions showing that performances fell far below expectations. Pickrell (1992) found that ridership numbers on each of the eight rail systems he studied failed to meet their forecasts, and often did not even reach half of the expected patronage. Expected capital outlays were underestimated compared to actual outlays, and annual operating expenses were higher than forecast in all but one of the eight systems (Pickrell, 1992). In another study, the claims that rail transit systems in cities would increase overall transit ridership and improve financial performance were investigated and found not to have been realized (Richmond, 1998). Budget deficits were found to be a major factor in the finances of the Massachusetts Bay Transportation Authority (MBTA) in Boston, as continued hesitancy to raise fares over fear of losing transit ridership created ballooning transit deficits (Gomez-Ibanez, 1996). With few exceptions, ridership has generally fallen short of forecasts made at the time rail projects were proposed, and has had a negative effect on the financial productivity of the transit systems in question (Richmond, 1998).

Light rail systems in Buffalo and Trenton have been prominent examples of light rail projects gone wrong (Pucher, 2004). They demonstrate that rail investment alone is 
not sufficient to promote economic development in areas that are experiencing economic decline, and that rail investments are much more successful in areas already growing economically (Giuliano, 2004). A federally sponsored impact study of three of the first heavy rail systems (The Bay Areas's BART, Washington's Metro, and Atlanta's MARTA) found that they failed to meet expectations, and all but the Washington METRO did not reach ridership projections (Giuliano, 2004).

A more comprehensive study investigating the performance of four US urban rail systems, including the Miami Metrorail (heavy rail), St. Louis Metrolink, San Diego Trolley, and Sacramento light rail systems, specifically addressed ridership and financial statistics in addition to analyzing factors driving the performance numbers (BabalikSutcliffe, 2002). Success of each rail transit system was defined in terms of fulfilling its investment expectations as measured by high patronage, cost effectiveness, increasing public transport usage, and having a positive effect on land use and urban growth patterns. In Table 3.1, some of these key figures are summarized. 


\begin{tabular}{|l|r|r|r|l|l|}
\hline Rail System & $\begin{array}{l}\text { Projected } \\
\text { Patronage }\end{array}$ & $\begin{array}{l}\text { Actual } \\
\text { Patronage }\end{array}$ & $\begin{array}{l}\text { Difference } \\
(\%)\end{array}$ & $\begin{array}{l}\text { Annualized } \\
\text { capital cost } \\
\text { per passenger } \\
(£)\end{array}$ & $\begin{array}{l}\text { Farebox } \\
\text { recovery } \\
\text { ratio (\%) }\end{array}$ \\
\hline $\begin{array}{l}\text { Miami } \\
\text { Metrorail }\end{array}$ & 202,000 & 36,000 & $-82 \%$ & 6.46 & 29 \\
\hline $\begin{array}{l}\text { St Louis } \\
\text { MetroLink }\end{array}$ & 13,000 & 24,515 & $89 \%$ & 1.47 & 46 \\
\hline $\begin{array}{l}\text { San Diego } \\
\text { Trolley }\end{array}$ & 9,500 & 12,000 & $26 \%$ & 2.18 & 68 \\
\hline $\begin{array}{l}\text { Sacramento } \\
\text { LRT }\end{array}$ & 20,500 & 12,000 & $-42 \%$ & 1.68 & 40 \\
\hline US Average & N/A & N/A & N/A & 3.1 & 25 \\
\hline
\end{tabular}

Table 2.1: Previous Research. Ridership and financial performance of systems in Babalik-Sutcliffe (2002).

Some of the factors behind the successes of these systems were joint development projects, integration with existing transit services, and TOD developments. Conversely, weak CBDs, low density urban forms, and weak integration with existing transit services hindered their success (Babalik-Sutcliffe, 2002).

As previously noted, most of the existing literature has focused primarily on evaluating rail transit systems as a whole rather than breaking them into their component corridors. While a gap exists in existing research, the corridor level is not a new approach to studying urban rail transit. Pushkarev, Zupan, and Cumella (1982) conducted one of the first national assessments for corridors suited for new urban rail projects, and identified specific corridors ripe for rail transit development. Their focus on fixedguideway transit provides the cornerstone of today's growing urban rail corridors, and many of the urban corridors they originally identified based on city configurations and 
passenger-mile thresholds have seen light rail development (Pushkarev, Zupan, and Cumella, 1982; Ratner, 2001).

\subsection{Known Factors in Successful Rail Transit Systems}

Previous studies have attempted to attribute rail transit system performance to certain factors. These elements needed to foster high ridership are of obvious interest to practitioners and transit agencies. The Transit Cooperative Research Program (TCRP) has investigated this topic in multiple reports. Ridership levels and transit's market share are strongly associated with greater densities, but are also affected by the level of transit inducing activities, the price and other characteristics of the service, alternative transportation options available, and characteristics of the population served (TCRP Report 88, 1997). Academic studies have reaffirmed the importance of population density and income measures (Taylor et al. 2009), as well as of employment density (Barnes, 2005). Service frequency, bus line connections, park and ride spaces, and the percentage of renters within walking distance are other factors found to be positively associated with ridership (Evans, 2004; Kuby et al. 2004).

Some of the most significant factors affecting transit ridership have also been found to be external to the transit systems themselves. Very strong relationships between ridership on a system and the local unemployment rate, real hourly wages, and real GDP have been found (Taylor and Haas, 2002). Internal transit agency factors that made a difference included fare changes, marketing techniques, and service improvements, even though their impact was minimal when compared to economic conditions (Taylor and 
Haas, 2002). Transit agencies employ various strategies to create higher ridership, most commonly operating and service adjustments, but marketing and fare-related actions have been used as well (TCRP Report 111, 2007). Because they are often carried out together, there is limited evidence that any one strategy is more effective in boosting ridership than others (TCRP Report 111, 2007).

Researchers have also studied the conditions and characteristics necessary to support fixed guideway transit investments and provide guidance on evaluating proposed investments based on these conditions. A recent report took a fresh look at concepts originally presented by Pushkarev, Zupan, and Cumella (1982), and found that employment and population densities near stations were very predictive of daily ridership (TCRP Report 167, 2014). Additionally, having high costs for parking in the CBD, high road congestion, and grade separation were influential on daily ridership, more so than factors such as the size and accessibility of the existing network or walkability (TCRP Report 167, 2014).

In sum, existing literature has contended with the question of how to measure system performance, although no widely agreed upon methodology currently exists. Previous studies have found a number of predictive factors in the performance of light rail systems, which will be further investigated in this research. 
CHAPTER 3: HISTORY OF NEW STARTS AND LIGHT RAIL IN STUDY CITIES

This chapter briefly discusses the history of the Federal Transit Administration's (FTA) New Starts program and its current role in funding urban rail transit projects. It also delves into the history of rail transit development in each of the cities in the study, with attention paid to the politics and funding involved in completing each new corridor.

\subsection{FTA New Starts Program}

The Urban Mass Transportation Act of 1964 created the FTA's predecessor, the Urban Mass Transportation Administration (UMTA), and first established funding for the New Starts grant program. However, most of the funds in the first decade were used in a preservationist role to convert bankrupt private transit companions into public transit agencies (UMTA, 1976). But in 1976, the program was reformed and amended to focus more on creating new rail transit investments, formalizing a process of requiring cost and ridership forecasts as evaluation criteria based on cost effectiveness metrics, essentially creating the New Starts program that exists today (Duff et al. 2010).

New Starts falls under the larger umbrella of FTA's Capital Investment Grant program, which has been and continues to be the primary mechanism for funding urban rail transit projects in the US. The Capital Investment Grant program also includes subcategories termed New Starts, Small Starts, and Core Capacity, all of which aim to 
provide funding for fixed guideway investments like light rail, commuter rail, streetcars, and bus rapid transit (FTA, 2018a). Core Capacity provides funds to projects that will increase the capacity of existing fixed guideway systems by ten percent or more, and Small Starts provides funds to projects that are estimated to have a total cost of $\$ 300$ million or less (FTA, 2018a). The New Starts program, which is available to new fixed guideway projects estimated to cost $\$ 300$ million or more, is older than these other more targeted programs and has thus provided the majority of funds for rail development. Over the past twenty years, the FTA has allocated more than $\$ 3$ billion dollars per year to urban rail transit projects through the New Starts program (Voulgaris, 2017).

The New Starts program is referred to as a discretionary and competitive federal grant program, which means that demand for the funds exceeds the available supply (FTA, 2018b). Each project sponsor, usually the transit agency applying for the funds, must go through a multistep and multiyear process of providing the FTA with specific figures on predefined criteria at multiple points through the project development process (FTA, 2018a). Through FAST Act authorizations, the program is allocated $\$ 2.3$ billion per year through 2020, although the amount could be subject to change depending on congressional and presidential budgets (FTA, 2018a). The FAST Act also limits the maximum amount of funds any given project may receive through the New Starts program to 60 percent of the total project cost, with the maximum contribution allowed from all federal sources being 80 percent of the total cost (FTA, 2018a).

Once a project sponsor has applied for funds through the New Starts program, it begins a three step process: Project Development, Engineering, and Full Funding Grant 
Agreement (FTA, 2018b). The major steps in Project Development are completing the environmental review process, including the development of alternatives including the no-build or enhanced bus service options. The locally preferred alternative must then be built into a long range transportation plan to move forward (FTA, 2018b). The Engineering step requires the completion of sufficient engineering and design, and securing the portion of the funds for the project that will not be covered through the New Starts program. Once a project can fulfill these requirements, a Full Funding Grant Agreement is reached to begin construction (FTA, 2018b).

Since New Starts is a competitive grant program, the FTA also undertakes a project evaluation and rating process as part of each application. The overall project rating is weighted 50 percent by the Local Financial Commitment and 50 percent by the Project Justification, which includes measures such as congestion relief, environmental benefits, mobility improvements, and economic development, among others (FTA, 2018b). Both the Local Financial Commitment and Project Justification portions must each receive a "Medium" or better rating for the project to receive an Overall Project Rating of "Medium" or better, which is the baseline requirement to qualify for New Starts funding (FTA, 2018b). Although the original New Starts program did not require any type of follow up study to determine if projected ridership and financial forecasts had materialized, a rule change in 2000 mandated the completion of Before and After Studies for this purpose (Voulgaris, 2017).

The rapid expansion of light rail systems across the Sunbelt in the previous few decades would not have been possible without the funding provided by the New Starts 
program. Even though the program has been slightly amended with each new major transportation bill passed by Congress, the program established in 1976 remains in similar form today, providing the necessary support and funding to fuel urban rail transit development.

\subsection{Background of Light Rail in Denver}

The Regional Transportation District (RTD) was created by the Colorado General Assembly in 1969 to operate a mass transportation system for residents of Denver and its surrounding suburbs (RTD, 2018a). In addition, RTD was tasked with developing a plan for future urban rail transit in the region, since its once extensive urban streetcar system folded in 1950. By 1972, RTD had created a plan for personal rapid transit (PRT), which called for nearly one hundred miles of the podcar transit technology on fixed guideways throughout the metro area to complement bus service (Ratner, 2001). The plan for PRT was later revoked in favor of light rail technology, but not before voters in the six counties in RTD's service territory approved a 1973 measure that raised sales tax by 0.5 percent to fund expanded bus service and PRT (Ratner, 2001). The 1973 PRT plan was rejected by UMTA for federal funding, and RTD dropped planning for PRT in 1975.

Using only existing tax measures, RTD opened its first light rail line in 1994 from the Five Points neighborhood northeast of downtown to I-25 and Broadway, running through the heart of Denver's business district and its downtown college campus along its 5.3-mile route (RTD, 2018a). The right of way utilized was a mix of an existing freight rail corridor and an alignment on city streets. Strong ridership helped generate public 
support for more light rail in the region, using the Central corridor as a demonstration line for future expansion which branched out from the main stem.

The first of these was the Southwest corridor, which connected the southwestern suburb of Littleton to the light rail system via the same existing freight rail corridor. RTD began the process to apply for New Starts funding for the line in 1992, and worked its way through the environmental and engineering steps in the 1990s before opening to the public in 2000 (RTD, 2018a).

Another line to branch off from the original stem was the Central Platte Valley line, branching off to provide access to sports and events venues and Union Station traversing mostly underutilized land along the west side of downtown. This corridor opened in 2002 and was funded entirely through the use of local funds, much as the Central corridor had been (RTD, 2018a).

As the Denver region continued to grow throughout the 1990s, local governments began to collaborate in searching for a solution to growing congestion on the I-25 corridor running southeast from downtown. After environmental work was complete, the Transportation Expansion Project (T-REX) began in 2001 with the joint mission of widening the I-25 freeway and constructing a light rail line parallel to it (RTD, 2018a). The project was financed jointly through voter approved bonds and funds from the New Starts program. The Southeast corridor opened to the public in 2006, and included two branches: One that follows I-25 to Lone Tree (Lincoln Ave) in Douglas County and 
another that splits off and parallels I-225 to Nine Mile (Parker Rd) in Aurora (RTD, 2018a).

In 2004, voters approved a tax increase measure to fund RTD's new Fastracks program, which promised 122 miles of new light rail and commuter rail, 18 miles of bus rapid transit, and 57 new transit stations. The ambitious, decades long program included the West and Airport lines, more recently opened lines along I-225 in Aurora and from downtown to Westminster, and future lines to Arvada, Thornton, and Boulder/Longmont. In addition, extensions to the Southwest and Southeast corridor, bus rapid transit to Boulder, and Union Station renovations, among other projects, were part of the measure (RTD, 2018a). The Fastracks program provides a dedicated source of local funds to bolster RTD’s New Starts proposals, with four new rail corridors already having been opened.

The first corridor opened as part of the Fastracks program was the West corridor, running from downtown Denver to Golden in west suburban Jefferson County using a mix of an abandoned rail corridor, parkland and highway rights of way. Design and planning took place in the years following the Fastracks vote, with full construction beginning in 2009 once New Starts funding was secured (RTD, 2018b). A new Federal Center bus terminal and bike paths paralleling the corridor were also part of the project, which opened to the public in 2013 (RTD, 2018b).

Denver's first commuter rail corridor was developed as part of a public-private partnership pilot program sanctioned by the FTA. A 34-year agreement with private 
entity Denver Transit Partners to operate both the new line linking downtown Denver to the airport and two other new rail corridors packaged together as the Eagle P3 project was financed through New Starts funding, Fastracks revenues, and money invested by the contractor (RTD, 2018a). The line to Denver International Airport was opened in 2016, and is the last corridor in Denver that will be included as part of this study because ridership data for later corridors were not available on time for a full analysis. Even though it utilizes commuter rail technology and not light rail technology, it does form a major urban rail corridor radiating out from downtown to serve Denver's neighborhoods, and is thus included in the study. Figure 3.1 provides a map of Denver's rail system.

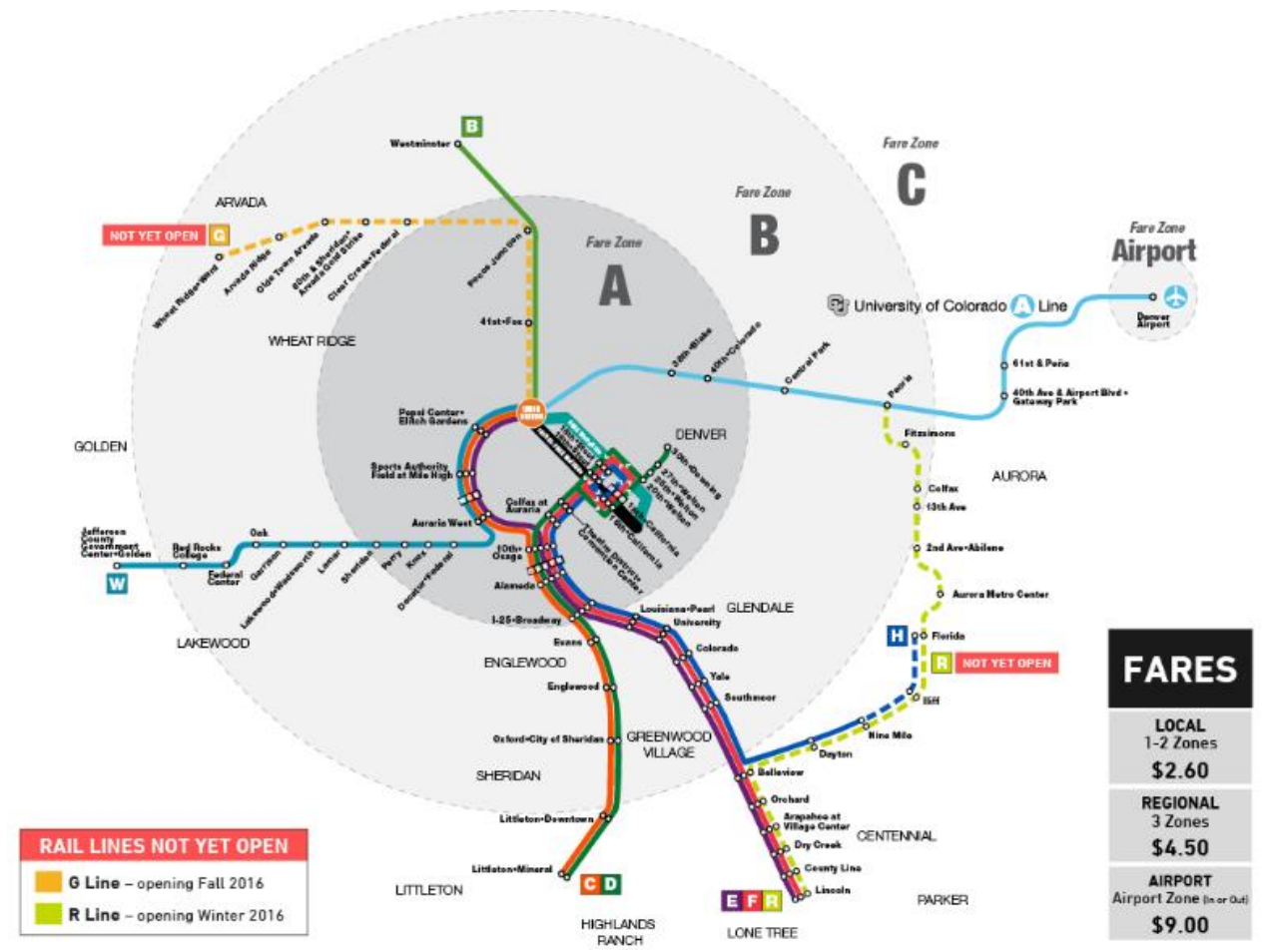

Figure 3.1: Map of Denver light rail system. Note that some corridors included on this map are not yet open and will thus not be included in the study, namely the line running north from downtown and the north-south $\mathrm{R}$ line on the east side of the map. 


\subsection{Background of Light Rail in Salt Lake City}

The Utah Transit Authority (UTA) was established in 1970 when residents from Salt Lake City and the surrounding municipalities of Murray, Midvale, Sandy, and Bingham voted to form a public transit district with the blessing of the Utah legislature, following the failure of private companies to provide public transportation services to residents (UTA, 2018a). Today, it has a service territory that encompasses more than 80 percent of the state's residents, largely organized along a natural corridor from Ogden in the north to Provo in the south (UTA, 2018b). At first, UTA provided local residents with reliable bus service, but began shifting toward planning a regional urban rail transit system in the 1980s and 1990s. The initial proposals for light rail development arose from growing concerns about congestion on I-15, but were met with criticism. However, $\$ 5$ million was appropriated by Congress to purchase an existing right of way paralleling I-15 southwards from downtown to keep the door open to light rail in the future (United Press International, 1988).

In 1995, when Salt Lake City was awarded the 2002 Winter Olympics, UTA used the opportune moment to apply for New Starts funding for an initial light rail line running south from downtown Salt Lake City to Sandy. Construction began on this Central corridor line in 1997, and it opened in 1999 (UTA, 2018a). The new light rail service, known as TRAX, was embraced by local residents, and previous suspicions about the prudence of investing in rail transit were quickly challenged. 
The second line to open was the University line, linking downtown Salt Lake City to Rice-Eccles Stadium on the University of Utah campus with a city street alignment. Again, Salt Lake's host city status for the Olympic Games undoubtedly played a role in securing federal funds to build a project to serve the stadium where the opening and closing ceremonies would be held. The original line opened in 2001, and a short extension to the University of Utah's medical center was completed in 2003 with the assistance of a successful New Starts proposal, even though the Olympics had already left town (UTA, 2018b).

In 2006, a general transportation quarter-cent sales tax hike was approved by Salt Lake County voters. Although it was originally intended to be a general transportation tax hike, the Salt Lake County Council directed most of the revenue to UTA's proposed new light rail lines to West Valley City and South Jordan (Warburton and Dethman, 2006). With a local funding source secured, UTA was able to pitch their future corridors to the FTA for New Starts funding as a package deal and not the typical one-by-one approach, according to UTA's general manager (Warburton, 2007). This allowed UTA to fast track their process forward in a way that avoided some of the normally lengthy federal funding process. Through this memorandum of understanding between UTA and the FTA, only 20 percent of the funds for these corridors was required to come from local funding sources (Warburton, 2007).

First on UTA's priority list for new TRAX light rail corridors were the lines to West Valley City and South Jordan, both of which used ad hoc alignments along existing roadways and vacant land. These two corridors opened within a month of each other in 
2011. (UTA, 2018b). With these lines finished ahead of schedule, tax revenue was then free to fund projects further down UTA's light rail wish list, namely the extension of the original line south from Sandy to Draper, and the construction of a line to Salt Lake City International Airport. The airport line and Draper extension both opened in 2013 (UTA, 2018b).

In addition to the six light rail corridors, UTA has also invested in a Wasatch Front regional commuter rail line, stretching 89 miles from the city of Ogden in the north to Provo in the south, opening its northern and southern sections in 2008 and 2012, respectively (UTA, 2018a). A streetcar line was also opened in 2013 serving Salt Lake City's Sugar House neighborhood. These lines will not be considered as part of this study, since the commuter rail line has a length far out of line from other corridors in the study, and the streetcar line does not connect to downtown Salt Lake City. Figure 3.2 provides a map of Salt Lake City's rail system. 


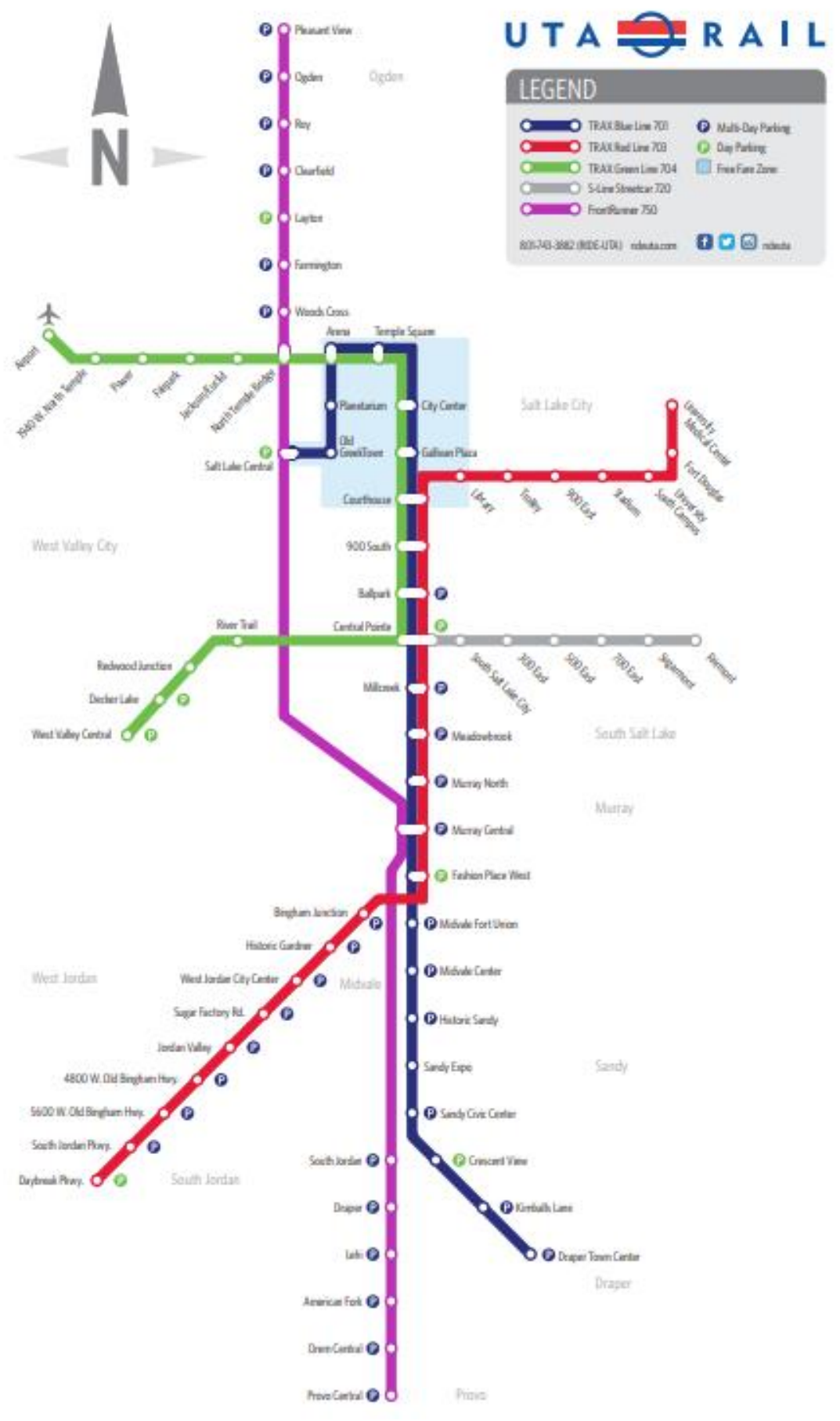

Figure 3.2: Map of Salt Lake City light rail system. Note that the longest north-south line is a commuter rail line linking Provo and Ogden that will not be included in the study, and the east-west line further south between Central Pointe and Fairmount is a streetcar line that will also not be included in the study. 


\subsection{Background of Light Rail in Portland}

By the late 1960s, Rose City Transit Company, the primary provider of transit services in Portland, was on the verge of bankruptcy. In 1969, TriMet was created with the help of the City of Portland and the Oregon legislature to consolidate bus transit services in the city (TriMet, 2018a). Most talk of transportation investments in the region at that time was of new expressways for which federal money was readily available, until the 1973 Federal Highway Act allowed states to transfer funds from interstate system projects to alternative projects. Local jurisdictions requested that funds from the proposed Mt. Hood Freeway project be redirected to transit projects, and in 1980, federal approval was received for use of these funds on a light rail transit project (TriMet, 2018a).

TriMet's proposed first light rail line ran eastward from downtown Portland along the existing Banfield expressway, and then along Burnside Street into Gresham. Outside of a line that had just opened in San Diego, Portland was the first city to use light rail technology in the US (TriMet, 2018b). The 15-mile line opened in 1986, which became known as the Metropolitan Area Express, or MAX.

Following the success of the MAX line to Gresham, a second line was proposed to run west from downtown Portland to suburban Beaverton and Hillsboro, primarily along an existing rail corridor. Portland's regional council of governments, Metro, had adopted an urban growth boundary in 1979, and by the 1990s, there was an increasing focus on increasing density along major transportation and light rail corridors to prevent sprawl (TriMet, 2018a). Furthermore, Nike (headquartered in Beaverton) and Intel (with 
a major office in Hillsboro) were strongly in favor of the project. After tunneling under the West Hills with three-mile long twin transit tunnels, the light rail extension to Beaverton and Hillsboro opened in 1998. Primarily funded through New Starts, the line was also funded in part by a local bond measure to make up what was not covered by New Starts and Oregon state transportation funds (TriMet, 2018b).

A bond measure, put on the ballot in 1998 to help fund a proposed light rail corridor from North Portland to Milwaukie, was narrowly rejected by voters. A similar bond measure for a north-south corridor had previously passed in Oregon but had been rejected by voters in Washington, where it was to have a northern terminus in Vancouver (TriMet, 2018a). Despite the setbacks for a north-south light rail transit project, TriMet turned to a building blocks approach to continue to expand the system. In downtown, TriMet was working on developing its modern streetcar system. It was also laying the groundwork for the new Interstate MAX line to North Portland, following the proposed alignment of the same north-south light rail line that had been defeated in 1998 (TriMet, 2018a).

The most rapid progress, however, was made on its extension to the airport from the existing line to Gresham. Through a public-private partnership between TriMet, the City of Portland, private developers, and the operator of the Portland airport, construction began in 1999. The project did not use any New Starts funding or local tax increases to fund its construction, expediting the process and allowing it to open in 2001 (TriMet, 2018b). 
Construction began on the Interstate MAX line in 2000. Funds from the New Starts program, TriMet capital funds, and urban renewal funds were able to fill in the gap despite not having a bond measure in place (TriMet, 2018b). TriMet also set a strong precedent for community engagement in the light rail planning process in the underserved communities in North Portland, along Interstate Avenue where the line runs down the median. The corridor opened ahead of schedule and significantly under budget in 2004 (TriMet, 2018b).

The next light rail corridor built was the line paralleling I-205 from the existing Gresham line south to Clackamas Town Center. Funded through a combination of New Starts money and local funds, the line opened in 2009 (TriMet, 2018b). The most recent addition to MAX system is the corridor south to Milwaukie, which opened in 2015. With a final price tag of nearly $\$ 1.5$ billion, it far eclipsed any previous MAX project in terms of cost. Only 50 percent of the total cost was covered by the New Starts program, leaving a significant portion to be made up by local contributions (TriMet, 2018b).

TriMet is actively planning its next light rail corridor, which will stretch southwest from downtown Portland to Tigard and Tualatin along Barbur Boulevard. The question of funding what is likely to be another expensive project is a challenge, as TriMet is currently weighing pushing a new bond measure to fund the new light rail line in conjunction with road projects (Njus, 2017). Figure 3.3 provides a map of Portland's rail system. 


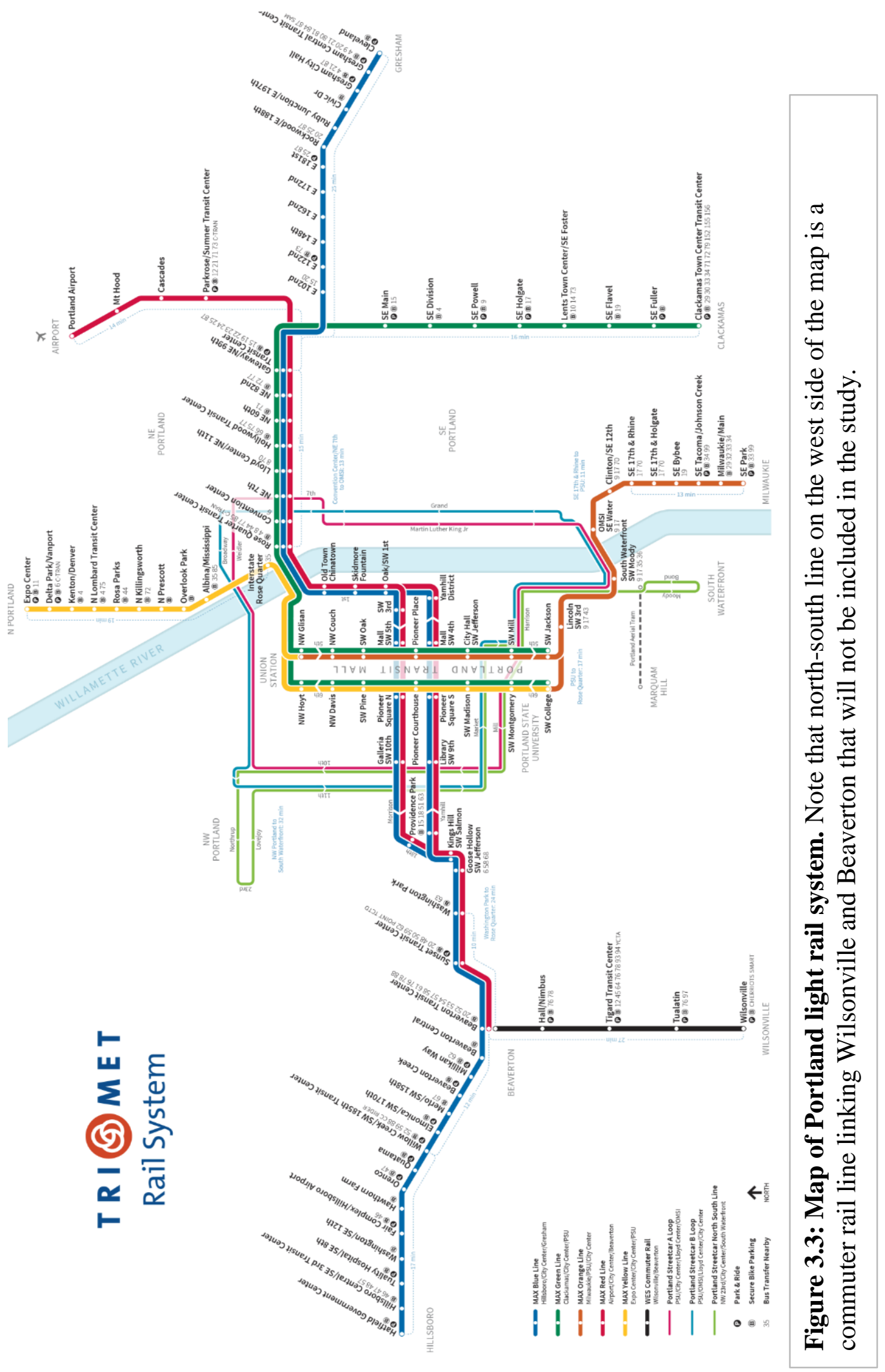




\section{CHAPTER 4: METHODS}

I employed a mixed methods approach to this research, relying on both quantitative data primarily from transit agencies, the National Transit Database (NTD), and the Census Bureau, as well as qualitative interviews with transit agency officials to conduct this study. Since the corridor is my chosen level of analysis, figures collected were aggregated or disaggregated to the corridor level as necessary for the nineteen corridors I investigated.

\subsection{Study Site Selection}

Three cities were selected as study sites for this project based on their comparable population sizes and years in which their light rail systems began operation. These cities are Denver, Salt Lake City, and Portland. Each city is discussed in a subsection below, and vital statistics are summarized in Table 4.1.

\begin{tabular}{|l|l|l|l|l|}
\hline Study Site & $\begin{array}{l}\text { Metro Area } \\
\text { Service } \\
\text { Population }\end{array}$ & $\begin{array}{l}\text { Rail } \\
\text { Revenue } \\
\text { Hours }\end{array}$ & $\begin{array}{l}\text { Light Rail } \\
\text { Ridership }\end{array}$ & $\begin{array}{l}\text { Total Rail } \\
\text { Mileage }\end{array}$ \\
\hline Denver & $2,876,000$ & 651,279 & 26.4 million & 76 \\
\hline Salt Lake City & $1,883,504$ & 334,271 & 19.9 million & 45 \\
\hline Portland & $1,542,044$ & 528,900 & 38.2 million & 60 \\
\hline
\end{tabular}

Table 4.1: Study Sites. Summary of light rail system characteristics in three study sites. Source: National Transit Database. 


\subsubsection{Denver}

Denver's Regional Transportation District (RTD) operates The Ride light rail system for a metro area service population of 2.9 million, with its first line beginning operation in 1994. RTD now operates seven light rail lines which radiate out from the CBD. These collectively cover 76 miles of track and carry 86,900 daily riders. There are six distinct light rail corridors that were studied as part of this research. They are the Central corridor, Southwest corridor, Southeast corridor, Five Points corridor, West corridor, and Airport line corridor. It should be noted that the RTD has recently opened two new rail corridors - the Northwest corridor to Westminster and the I-225 corridor through Aurora - but data from these corridors was less than a year old as research for this project began.

\subsubsection{Salt Lake City}

Salt Lake City's Utah Transit Authority (UTA) operates the TRAX light rail system for a metro area service population of 1.8 million; its light rail began operating in 1999. UTA now operates three light rail lines, two of which pass through the CBD connecting different parts of the city and suburbs, and one of which runs from the CBD southward. They collectively cover 45 miles of track and carry 67,300 daily riders. There are six corridors which will be studied as part of this research. They are the Central corridor, the Sandy/Draper corridor, the South Jordan corridor, the West Valley City corridor, the University corridor, and the Airport corridor. 


\subsubsection{Portland}

Portland's TriMet operates the MAX light rail system for a metro area service population of 1.5 million. Operations began in 1986. TriMet now operates five light rail lines, two of which pass through the CBD connecting different parts of the city and suburbs, and three of which run from the CBD outward. They collectively cover 60 miles of track and carry 116,800 daily riders. There are seven corridors which will be studied as part of this research. They are the Gresham corridor, the Hillsboro corridor, the Clackamas corridor, the Milwaukie corridor, the Interstate corridor, the Central corridor, and the Airport corridor.

\subsubsection{Corridor Definitions}

Each of the nineteen corridors in this study was selected based on historical and geographical reasons. Most of the corridors in Table 4.2 were built as a single entity, although a few exceptions exist due to later extensions. In terms of geography, each corridor generally operates separately from all others in the same city, although some stations are used for more than one line, and these areas of overlap are noted or reclassified as a central corridor in each city. Central corridors in this study are notable because of their increased service frequencies due to the existence of multiple light rail lines serving the same corridor.

The Central Business District (CBD) of each study city was divided between all corridors entering it, with ridership apportioned between different corridors in order to

avoid double counting. For example, the $16^{\text {th }}$ Street and $18^{\text {th }}$ Street stations in the Denver 
CBD are on both the Central and Five Points corridor, so their ridership numbers are divided between the two. The percentage of ridership apportioned to each of the two corridors was determined by each corridor's average ridership figure; in this case meaning most of the ridership from the aforementioned stations was credited to the Central corridor which carries far more passengers than the Five Points corridor. Similar calculations were made for the Salt Lake City CBD. In Portland, the crossing in the CBD of the east-west Central and Hillsboro corridors and the north-south Interstate and Milwaukie corridors was used as the dividing line between corridors.

The figures in Table 4.2 thus reflect the mileage and published travel times between the first and last stations within each of the nineteen corridors. These will often be referred to as defined corridors for the rest of the paper. 


\begin{tabular}{|l|l|r|r|r|}
\hline & & $\begin{array}{l}\text { Year } \\
\text { Opened }\end{array}$ & $\begin{array}{l}\text { Corridor } \\
\text { Length } \\
\text { (Miles) }\end{array}$ & $\begin{array}{l}\text { Travel } \\
\text { Time } \\
\text { (Mins) }\end{array}$ \\
\hline Denver & Contral & 1994 & 4.2 & 15 \\
\hline Denver & Southwest & 2000 & 8.6 & 15 \\
\hline Denver & Southeast & 2006 & $10.8 / 13.5$ & $20 / 28$ \\
\hline Denver & Five Points & 1994 & 1.4 & 11 \\
\hline Denver & West & 2013 & 13.3 & 39 \\
\hline Denver & Airport & 2016 & 23.2 & 37 \\
\hline Salt Lake City & Central & 1999 & 11.2 & 35 \\
\hline Salt Lake City & Sandy/Draper & 1999 & 8 & 17 \\
\hline Salt Lake City & South Jordan & 2011 & 10.5 & 21 \\
\hline Salt Lake City & West Valley City & 2011 & 3.7 & 15 \\
\hline Salt Lake City & University & 2001 & 3.7 & 18 \\
\hline Salt Lake City & Airport & 2013 & 6.8 & 21 \\
\hline Portland & Central & 1986 & 6.8 & 26 \\
\hline Portland & Gresham & 1986 & 8 & 26 \\
\hline Portland & Hillsboro & 1998 & 17.7 & 51 \\
\hline Portland & Clackamas & 2009 & 6.7 & 17 \\
\hline Portland & Milwaukie & 2015 & 8 & 32 \\
\hline Portland & Interstate & 2004 & 6.9 & 29 \\
\hline Portland & Airport & 2001 & 5.7 & 13 \\
\hline
\end{tabular}

Table 4.2: List of Corridors. These are the nineteen corridors evaluated in this study, generally named for the endpoint of the corridor except in cases where another name has come into widespread use. Note that the Southeast corridor in Denver has two lengths and travel times, reflecting its two legs.

\subsection{Ridership and Financial Forecasting}

The first criteria examined to gauge corridor performance was whether each corridor met, exceeded, or fell short of the expectations initially outlined. Most of these projects received funding from the FTA, and were thus required to make initial projections. Although the requirement for a report on how these forecasts materialized 
was not added until 2000, final ridership and capital cost numbers were generally publicly available.

Upon further investigation, creating a performance metric based on how well ridership and capital costs matched their projections proved more difficult than expected. Because many corridors did not make use of federal funds, more difficult to find local numbers would have to be used for the Denver Central, Denver Five Points, and Portland Airport corridors. Corridors that have opened in the past few years, namely the Denver West, Denver Airport, Salt Lake City Airport, and Portland Milwaukie lines have not completed their Before and After Studies yet, which presented another hurdle.

Research also suggests that ridership and financial forecasts are often unreliable, and thus are poor criteria upon which to judge corridor performance. More recent research has found that these forecasts may be improving over time, which raises the question whether it is fair to judge a corridor that opened in the 1990s with one that opened in the 2010s when better forecasting methodology was used. Therefore, because of the twin problems of missing data and changes in the accuracy of forecasting with time, corridors performance relative to initial ridership and financial projections was not included in the performance metric constructed for corridors in this study. However, the figures that could be found are included and further discussed in the following chapter.

\subsection{Calculating Ridership}

The first criteria examined that was included in the corridor performance score was ridership. RTD, UTA, and TriMet use automatic passenger counter technology on 
many of their light rail vehicles, enabling them to measure ridership at the station level. Each transit agency was approached directly for these figures, which are generally stored internally. Depending on the procedure for each agency, tracking spreadsheets were either directly shared or had to be obtained through a formal public records request. Because ridership data availability at the station level was only available from one of the transit agencies beginning in 2013, only five years of ridership data spanning 2013-2017 were included in this study. Ridership numbers used reflect the sum of boardings and alightings for each station.

For each station included in one of the defined corridors, ridership numbers were aggregated up to the level of the corridor for analysis by summing the ridership of each station in the corridor. This created a total ridership figure for each defined corridor in the study. From these raw annual numbers, which were often calculated using the average of multiple ridership periods throughout the year (e.g., averaging the Winter, Summer, and Fall ridership calculation periods available from the transit agencies), two performance criteria were developed. The first was ridership per mile - defined simply as the average ridership recorded for each corridor averaged over the five years of data. The second was ridership growth, the average percentage growth or decrease in ridership experienced in each corridor over the five years of data. To minimize the volatility of ridership that recently opened corridors often experience, corridors opened between 2013 and present had the magnitude of their ridership growth figure halved. For example, an average annual percentage ridership growth rate of ten percent would only be credited for a five 
percent annual percentage ridership growth rate to control for how recently it has come into operation.

Specific ridership figures by station and by corridor for each year between 2013 and 2017 are available in Appendix A.

\subsection{Calculating Capital Costs}

Capital costs were included in the performance metric because of the significant construction and startup costs that any new corridor incurs. Creating a performance metric that tracks the ridership and ongoing operating costs without regard for the sunk costs associated with building the corridor would neglect an important financial metric. The final capital expenditures of each corridor were generally found on both the individual transit agencies' websites and on the Before and After Studies page of the NTD.

Adjusting for inflation was a major step in ensuring capital cost figures could be compared between corridors. Capital costs from the year of line opening were converted to 2017 dollars using the Bureau of Labor Statistics' Consumer Price Index calculator. In cases where one capital figure was given for a line that encompassed two defined corridors (e.g., the Central and Five Points corridors in Denver, the Central and Gresham corridors in Portland), the total capital cost was split based on the relative number of miles in each part of the corridor. In Salt Lake City, corridor extensions that opened after the original corridor had to be converted to 2017 dollars before they could be added to each other to determine the total capital cost for the corridor. 
Capital costs were then broken down on a per mile basis (in the same way ridership was) to create a comparable metric across corridors.

\subsection{Calculating Operating Costs}

The final measure of performance leaned on traditional FTA measures of success: service effectiveness figures including operating expenses per vehicle mile and per vehicle hour. Since these numbers are reported by each agency at the system-wide level, calculating operating costs at the corridor level required a disaggregation process. Each agency's reported average expense per vehicle revenue mile and per vehicle revenue hour for the years 2013-2016 was used for each corridor in the corresponding city.

To convert these raw per mile and per hour figures into operating expenses by corridor, the total number of vehicle miles and vehicle hours in each corridor had to be determined. Each agency was requested to provide the number of vehicles on each of its scheduled daily runs. For example, RTD provided information on how many of its scheduled runs on the Southeast corridor were two car consists, three car consists, or four car consists. Using these numbers, the total number of vehicles operating in each corridor every weekday, Saturday, and Sunday was computed.

With the total number of vehicles operating in each corridor determined, the next step was to multiply that number of vehicles by the length in miles of each defined corridor and the travel time in hours it takes to traverse the corridor based on published schedules. Finally, the total operating costs by corridor were calculated by multiplying the number of vehicle miles by the cost per vehicle mile, and by multiplying the number 
of vehicles hours by the cost per vehicle hour. To account for the inherently higher operating expenses that longer corridors have compared to shorter corridors, the total operating expenses were divided by each corridor's average ridership to create the operating cost per passenger served. The cost per passenger based on operating cost per mile and based on operating cost per hour were both preserved, as each captures an important service effectiveness metric at the level of the corridor.

Since each corridor may not truly cost the same amount to operate on a per vehicle mile and per vehicle hour basis, this operating cost methodology does not provide a perfect figure. However, it is an important best measure of the operational costs per passenger at the disaggregated corridor level. Specific figures on how the number of vehicles in each corridor was calculated is available in Appendix B.

\subsection{Performance Score}

Using the ridership, capital cost, and operating cost figures, a performance score was constructed for each corridor. Specifically, the inputs were ridership per mile, ridership growth, capital costs, operating cost per passenger based on vehicle mileage cost, and operating cost per passenger based on vehicle hourly cost. These are summarized in Table 4.3.

Initially, each of the five inputs were to be weighted at 20 percent in calculating the total final performance score, but the ridership growth numbers were found to be less telling than originally imagined. Many corridors did not see significant changes in ridership over the 2013-2017, meaning that even small increases or decreases could 
significantly reward or penalize corridors whose general trend in ridership is holding steady. Nationally, transit ridership has leveled off or decreased in the years following the Great Recession, and these corridors reflect that trend. Thus, to more accurately measure which corridors are performing stronger than others, ridership per mile was given a 30 percent weighting and ridership growth reduced to a 10 percent weighting.

Ridership per mile, ridership growth, capital cost per mile, etc., are not all measured in the same units, and necessarily had to be converted into a new metric for comparison. Each corridor was given a 0-100 score for each of the five input factors, with 100 being the high score and 0 being the low score. To determine what should constitute a middle of the road score of 50, data from the nineteen corridors for each of the input factors was averaged, and a number approximating that average was used as the 50 score. Observed performance that was greater than the approximate average received a score higher than 50, and observed performance that was lower than the approximate average received a score lower than 50. Much of the data was skewed, with a few corridors having extremely high ridership per mile, and a few corridors having very high capital and operating costs. As such, some corridors were awarded scores of 100 or 0 if their calculated score was higher than 100 or lower than 0 .

The only exception made to this calculation system was in regard to ridership growth in corridors that have opened in the past five years. Because recently opened corridors are prone to more drastic increases or decreases in ridership, the magnitude of any ridership change (growth or decline) was only factored in at half of the magnitude greater or less than 50 than a ridership growth statistic was treated for other corridors. 


\begin{tabular}{|l|c|}
\hline Input Factor & Weighting \\
\hline Ridership per Mile & $30 \%$ \\
\hline Ridership Growth & $10 \%$ \\
\hline Capital Costs & $20 \%$ \\
\hline $\begin{array}{l}\text { Operating Cost per } \\
\text { Passenger (Miles) }\end{array}$ & $20 \%$ \\
\hline $\begin{array}{l}\text { Operating Cost per } \\
\text { Passenger (Hours) }\end{array}$ & $20 \%$ \\
\hline
\end{tabular}

Table 4.3: Performance Score Inputs and Weightings. Note the weightings of different input factors in the final performance score.

The final performance score for each corridor was also calculated on a $0-100$ scale, with each of the input scores weighted at the amounts listed in Table 4.3. In addition to a single performance score, ridership and financial subscores were also calculated for each corridor. The ridership subscore retains in its calculation relative weighting of ridership per mile to ridership growth, and the financial subscore equally weights the capital costs, operating cost per passenger based on miles, and operating cost per passenger based on hours.

\subsection{Neighborhood Factors}

After the performance score had been constructed, the next step was to determine what might be responsible for the different levels of performance observed. Each of the nineteen corridors in this study traverse different urban landscapes that may impact their performance. Additionally, decisions made by each transit agency on investments in each 
corridor may have significant effects on their performance. In an effort to better understand what may be driving observed performance, several metrics about each corridor will be investigated. These are termed corridor characteristics throughout the study, and were chosen based on factors that were found to be significant in past research and on data availability. I break these potentially explanatory variables into neighborhood factors and transit factors.

The neighborhood factors considered were population density, median income, percentage renter occupied, percent in the labor force, job density, and walkability. The first four of these measures were available through Social Explorer at the census block group level. To determine which block groups should be included for each corridor, halfmile network distance buffers were constructed around each rail station in ArcMap. The network analyst tool was used to solve for the network within a half-mile of each station location. For Denver and Portland, Open Street Map was used for the station area network because it included better coverage of pedestrian paths and overpasses than Census Tiger road files. For Salt Lake City, the Census Tiger road files were used for the road network because Salt Lake City's Open Street Map had too many missing network junctions to be viable. Once the half-mile network buffers were constructed, a select by location operation was performed to select the census block groups that overlapped the buffers. The corridor station locations, half-mile network buffers, and overlapping census block groups for each city can be seen in Figures 4.1, 4.2, and 4.3. 


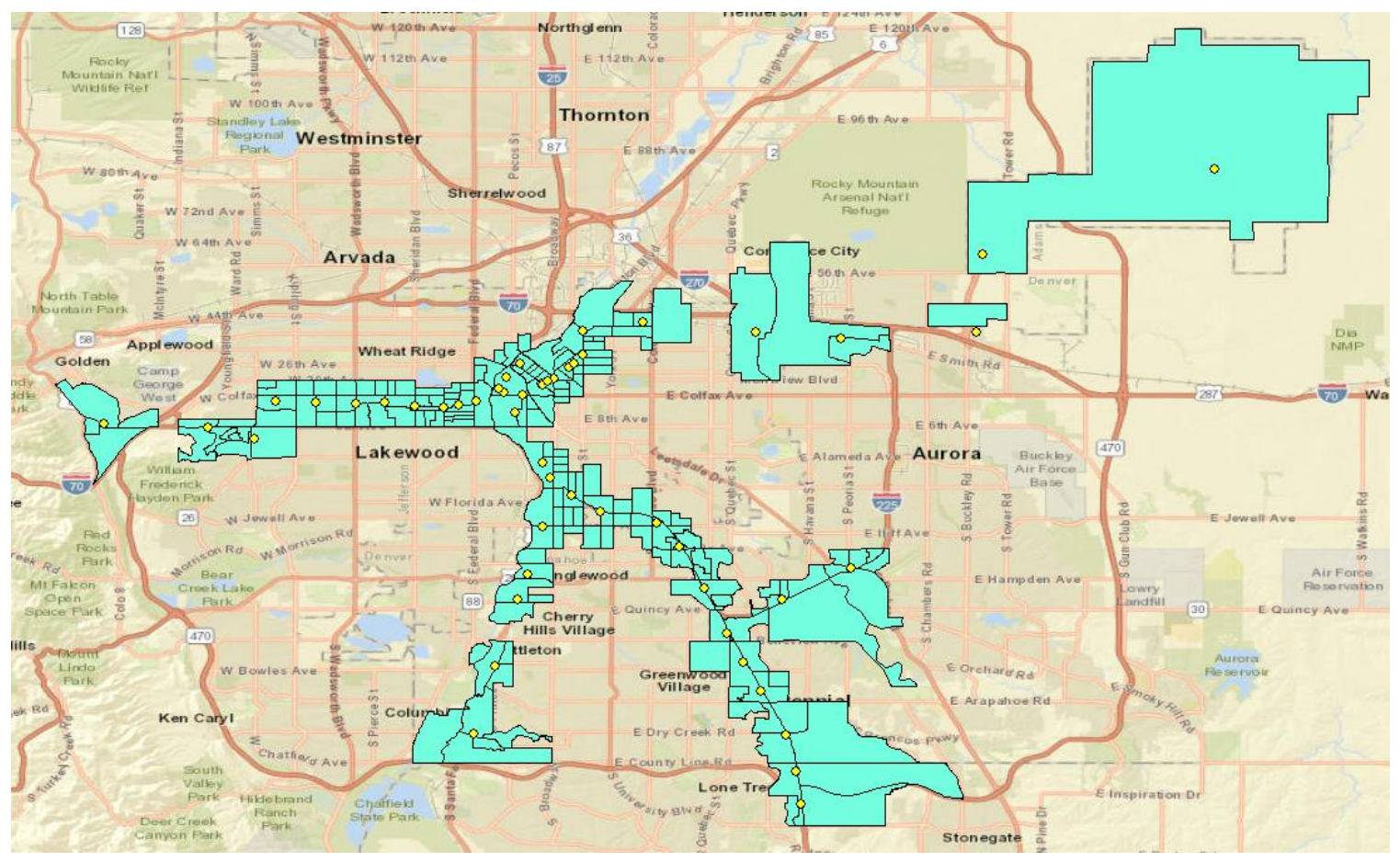

Figure 4.1: Map of Denver Block Groups. Open Street Map was used as the road network. Block groups which overlapped stations buffers are highlighted here, with station locations in yellow. 


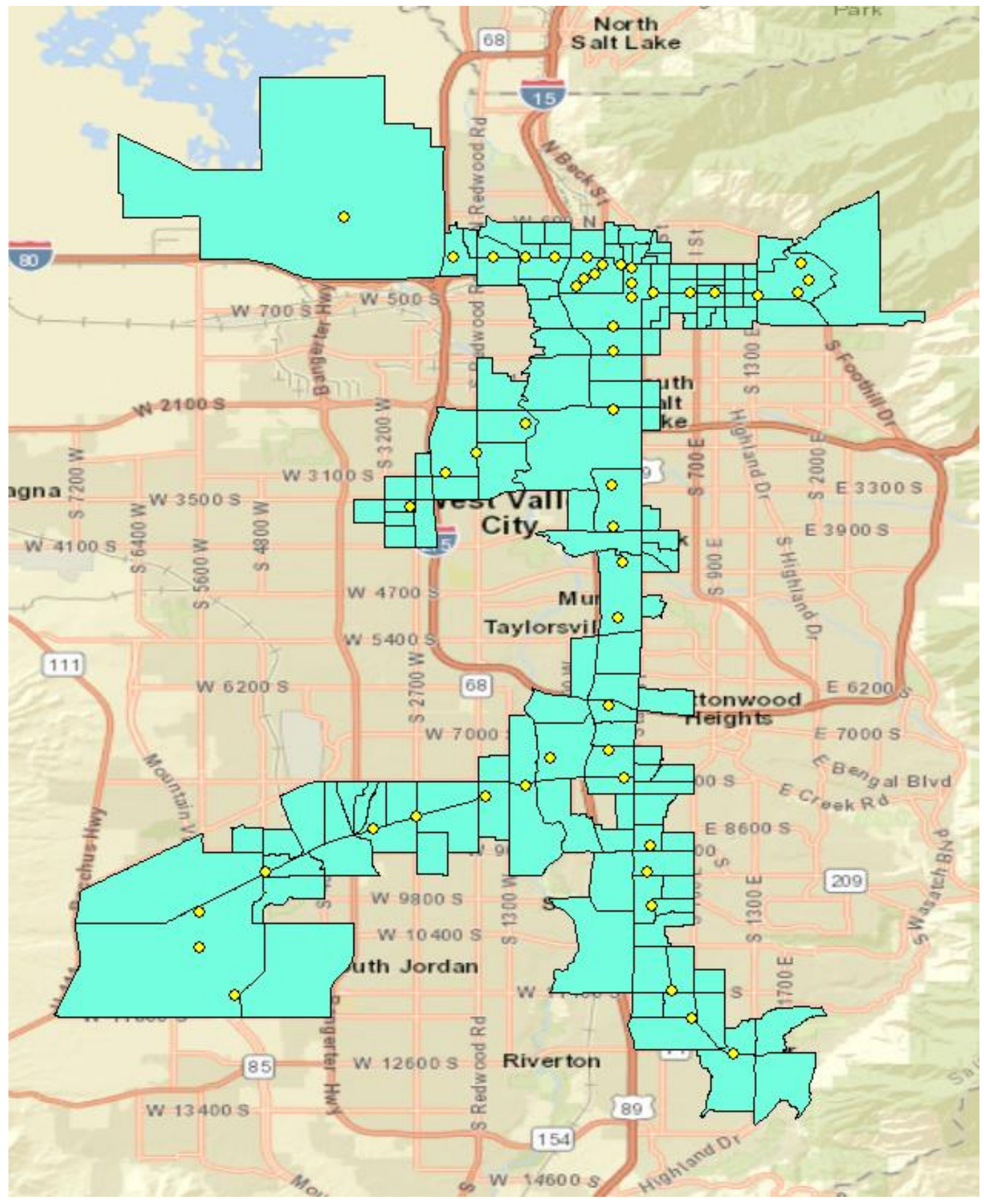

Figure 4.2: Map of Salt Lake City Block Groups. Census Tiger road files were used as the road network. Block groups which overlapped stations buffers are highlighted here, with station locations in yellow. 


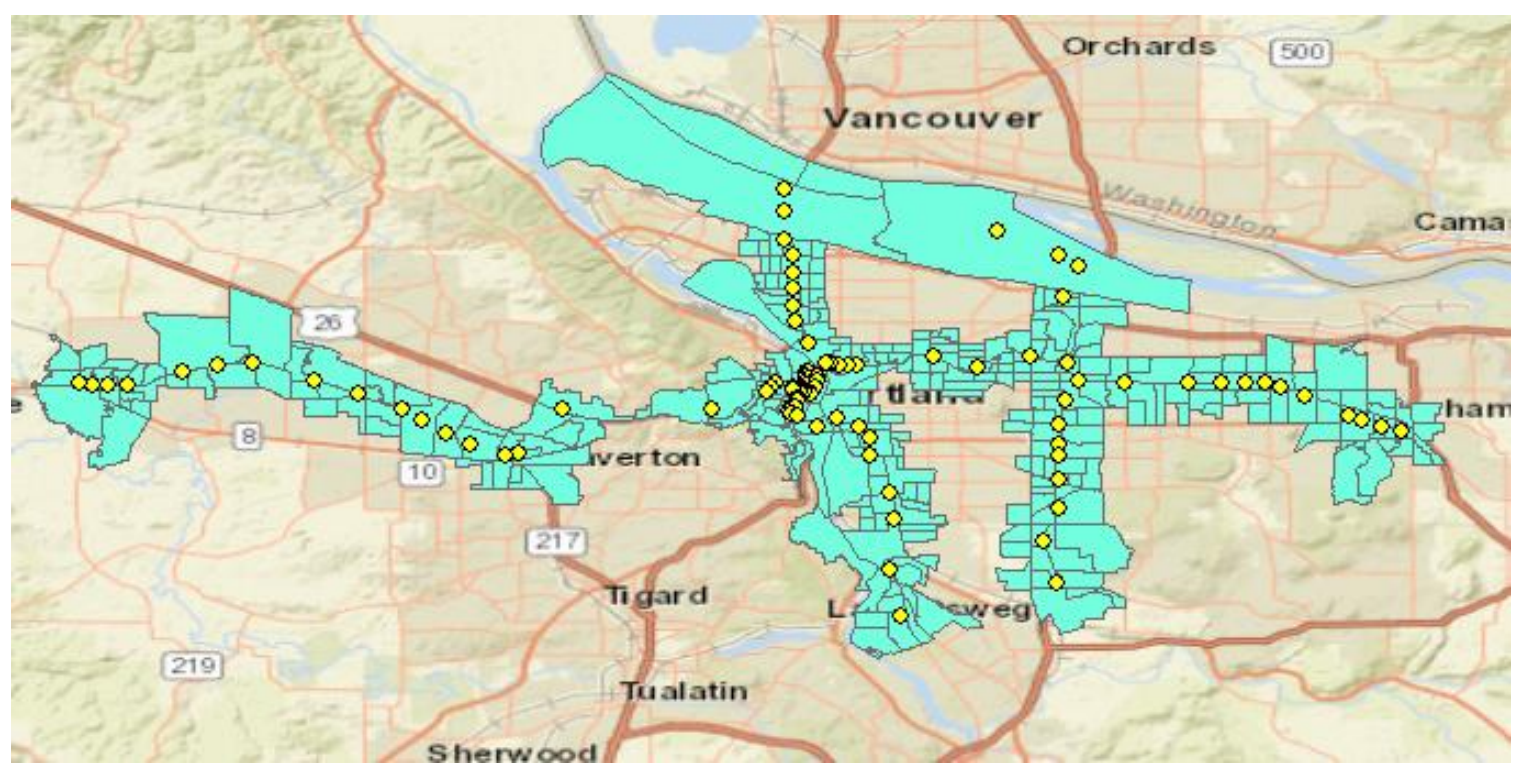

Figure 4.3: Map of Portland Block Groups. Open Street Map was used as the road network. Block groups which overlapped stations buffers are highlighted here, with station locations in yellow.

After the census block groups were isolated, numbers for population density, median income, percentage renter occupied, and percent in the labor force were procured from Social Explorer. Although these figures are most readily available via Social Explorer, their origin is US Census Bureau and American Community Survey data. Figures from the 2016 ACS (5-Year Estimates) were used for these measures. The block groups were not counted twice in a corridor if they fell in the network distance buffer of more than one station. Each defined corridor's average population density, median income, percentage renter occupied, and percent in the labor force was calculated by taking the mean from all of the block groups in the corridor. This methodology is comparable to how the ridership numbers were aggregated up from the station level to the corridor level. 
Job density was calculated using the Longitudinal Employer-Household Dynamics (LEHD) dataset, specifically the LODES 7 Workplace Area Characteristics information. LEHD statistics include the number of jobs in each census block, which were aggregated up to the block group level for this study. Using the same census block groups that were used for the Social Explorer calculations, job density was calculated for each corridor by averaging the number of jobs per square mile for all relevant block groups. A full listing of all block groups within the network distance buffers for each corridor can be found in Appendix C.

Walkability was the final neighborhood factor included, which serves as an indicator of both neighborhood connectivity and transit oriented development. The 0-100 WalkScore for each station location was taken as the score for walkability of the surrounding area. Although it is a private company, WalkScore's methodology reflects pedestrian accessibility and mixed use development through its measurement of the walking distance to nearby amenities like grocery stores, restaurants, and schools. Because no other apples-to-apples measurement for all three cities was available for transit oriented development or mixed use development, walkability can stand in as a reasonable proxy for these other factors. As with Social Explorer and job density data, the average Walk Score for each station will then also be aggregated up to the corridor level.

\subsection{Transit Factors}

Factors more specific to decisions made by the local transit agency were also considered as potentially explanatory variables for performance. Specifically, the number 
of park and ride spaces available at each station, number of bus connections at each station, the headways between trains, and average speed of trains within the corridor were included for analysis. Park and ride spaces and bus connections at different stations reflect each transit agency's plans and priorities for each corridor, and can also be more rapidly changed relative to neighborhood factors. Since the number of park and ride spaces and bus connections will likely be larger in longer corridors, the average number per station for these measures was used for analysis. For example, if a corridor collectively had 12 bus route connections and 8 stations, its average number of bus connections per station (1.5) was used.

Headways, or the amount of time between each train, were also considered. Separate headway measurements were taken for weekday rush hours, weekday non-rush hours, and weekends since headways between trains usually change based on these temporal characteristics. To calculate the average headway between trains, the mean of the three measurements was used. The average train speed within each corridor was calculated by dividing the scheduled time to complete the length of the defined corridor by the defined corridor length in miles. For headways and average train speed, there is no station level component to be aggregated, as the number is uniform for the entire corridor.

All corridor characteristics, encompassing both the neighborhood factors and transit factors, are summarized in Table 4.4. 


\begin{tabular}{|l|l|}
\hline $\begin{array}{l}\text { Urban Factors in Corridor } \\
\text { Characteristics }\end{array}$ & $\begin{array}{l}\text { Transit Factors in Corridor } \\
\text { Characteristics }\end{array}$ \\
\hline $\begin{array}{l}\text { 1) Population Density (block groups } \\
\text { within half mile of network distance } \\
\text { of station) }\end{array}$ & $\begin{array}{l}\text { 1)Park and Ride Spaces (average } \\
\text { number per station) }\end{array}$ \\
$\begin{array}{l}\text { 2)Median Income (block groups } \\
\text { within half mile of network distance } \\
\text { of station) }\end{array}$ & $\begin{array}{l}\text { 2) Bus Route Connections (average } \\
\text { number per station) }\end{array}$ \\
$\begin{array}{l}\text { 3) Percentage Renter Occupied } \\
\text { (block groups within half mile of } \\
\text { network distance of station) }\end{array}$ & $\begin{array}{l}\text { 3) Headways between trains (separate } \\
\text { measurements for rush/non rush and } \\
\text { weekends) }\end{array}$ \\
$\begin{array}{l}\text { 4) Percent in Labor Force (block } \\
\text { groups within half mile of network } \\
\text { distance of station) }\end{array}$ & 4) Average train speed in corridor \\
$\begin{array}{l}\text { 5) Job Density (block groups within } \\
\text { half mile of network distance of } \\
\text { station) }\end{array}$ & \\
$\begin{array}{l}\text { 6) Walkability (WalkScore of station } \\
\text { location) }\end{array}$ & \\
\hline
\end{tabular}

Table 4.4: Corridor Characteristics. Summary of neighborhood and transit factors and their calculation methodology.

\subsection{Explaining Performance}

After both of the quantitative datasets (corridor performance and corridor characteristics) had been gathered, potential explanatory variables for corridor performance were explored. This analysis was completed through tests of regression and a correlation matrix, using the corridor characteristics as the independent variables and the performance scores as dependent variables. 


\subsection{Interviews}

To bolster information derived from the quantitative parts of this study, interviews were conducted in each city to include a qualitative assessment on the data collected and analyzed. Trends are sometimes not readily seen in lines of Excel, or other significant factors are overlooked without considering a more nuanced perspective of the data in question. Including this qualitative measure to ensure significant findings are robust and not just blips on a screen is crucial to effective analysis.

Interviews were conducted with ridership or service development experts at RTD, UTA, and TriMet for this part of the study. Additionally, a transportation expert at each local regional council of governments (Denver Regional Council of Governments in Denver, Wasatch Front Regional Council in Salt Lake City, and Metro in Portland) was interviewed. Interviewees were identified through a mix of existing contacts and searching the website of each transit agency and regional council of government to identify officials involved in ridership or service development. Thus, in each city in this study, one transit agency official and one local government official were identified and interviewed.

Most of the questions asked were uniform across each city in the study. Interviewees were asked about their own perspective of the history of development of light rail in the region, their thoughts on its success or lack thereof, and what major lessons have been learned. The research methodology and performance score criteria 
were also presented to the interviewees, who were encouraged to think about whether the defined criteria would result in a strong performance metric.

Other research questions were more site-specific based on the data already obtained from the quantitative portion of the study. The interviewees were first asked what they believed to be the stronger and weaker performing corridors in their city, and then presented with the performance scores for the corridors in their cities from this study. They were also asked what they believed were important corridor characteristics in driving strong performance, before being presented with the results of the regression tests.

IRB approval was obtained in October 2017 to conduct these interviews. As part of the IRB process, full confidentiality was given to interviewees so they could speak freely about both the successes and shortcomings of light rail in their cities without risk of retaliation. The interviews in Denver and Salt Lake City were completed in December 2017, and the interviews in Portland were completed in February 2018. A full list of questions during the interviews can be found in Appendix D. 


\section{CHAPTER 5: RESULTS}

This chapter presents the results of the study. This includes constructing the component parts of the performance score, the ranking of corridors by performance score, and the tests of regression that discovered correlations between the performance score and corridor characteristics. Results are not fully analyzed in this chapter, as a more thorough analysis integrating qualitative components of the study is presented in the following chapter.

\subsection{Forecast and Actual}

For those corridors in which data were available to compare forecasted ridership and capital costs (two in Denver, three in Salt Lake City, and three in Portland), the difference between the projected figures and final figures was calculated on a percentage basis. Final capital costs were overall much closer to their projections compared to ridership figures, with all final costs falling within plus/minus ten percent of forecasts. Projections were virtually spot on for the Southwest and Southeast corridors in Denver, and the original corridor in Salt Lake City. The South Jordan and University corridors in Salt Lake City were completed under budget forecasts, and in Portland, projects erred just higher than projected. Given that these projects cost hundreds of millions of dollars, capital costs were projected with a great deal of accuracy. 
It should be noted that some discrepancies existed between different sources for ridership and capital cost figures. Sometimes, previous FTA research quoted slightly different cost or ridership figures than those found on the transit agency's website. Other times, a broad statement such as "X corridor ridership exceeded projections" was made on a transit agency's website even though the Before and After study for the given corridor indicated that it had not met projections. When these discrepancies did exist, the FTA research was used. However, because some of this research was published before the end of ridership forecast horizons, estimates on progress toward ridership projections was used in lieu of observed ridership figures. These are referred to as Reported Ridership in Table 5.1. Observed ridership figures from this study were also included for comparison purposes with these reported ridership figures.

According to the reported ridership figures, four of the eight corridors exceeded their projected ridership, and four fell short. However, using the actual ridership figures from this study showed that six of the eight corridors exceeded their projected ridership. In some cases, this can likely be attributed to the corridors being open for years that extended beyond the original ridership forecast horizon. In others, actual ridership has shown that ridership estimates from earlier FTA studies was significantly different from subsequent observed ridership.

All forecasts and actual data are summarized in Table 5.1. 


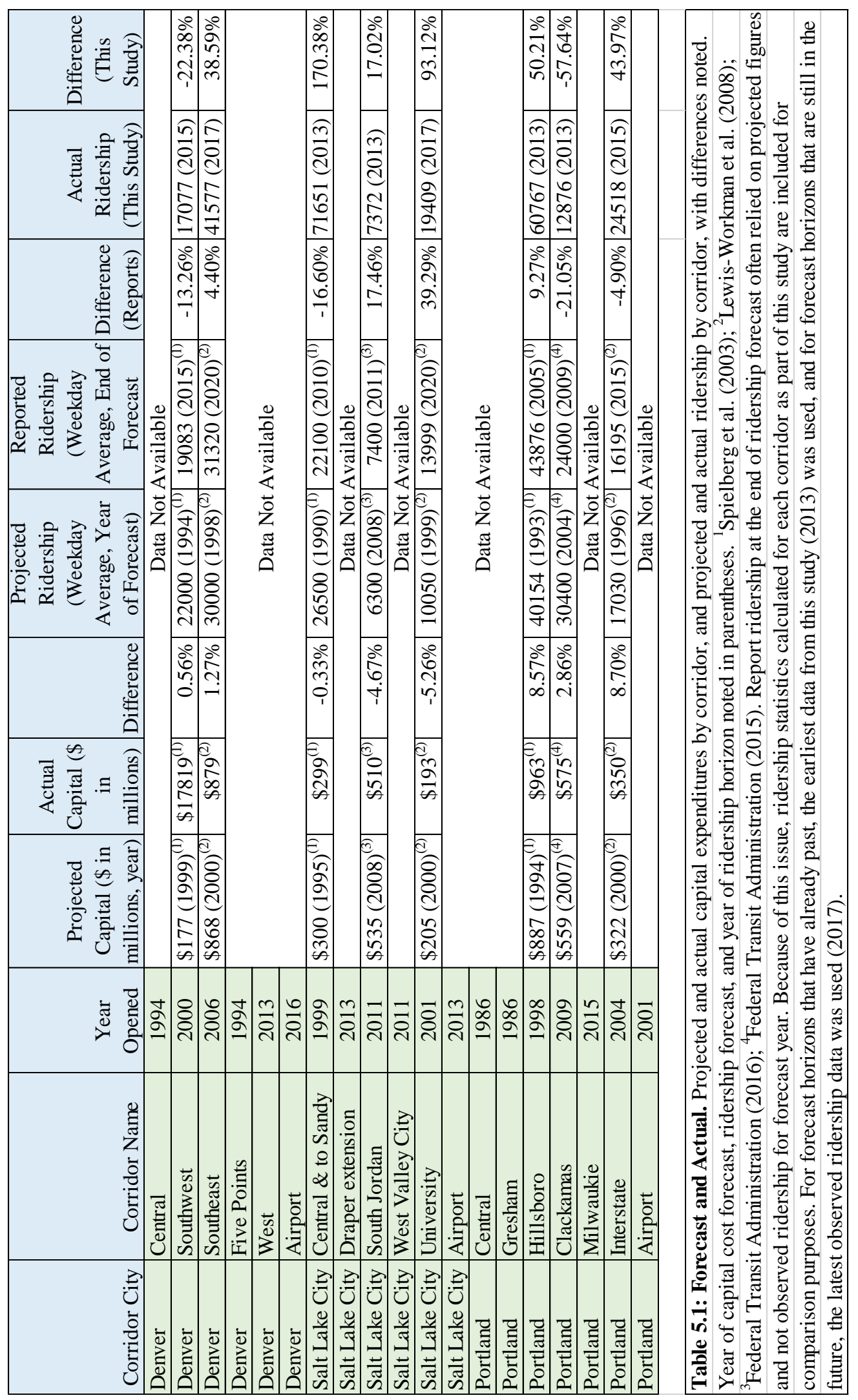




\subsection{Performance Scores}

Average ridership was calculated for each corridor, yielding figures that ranged from 5340 average weekday riders on Salt Lake City’s West Valley City corridor to 67,340 average weekday riders on Denver's Central corridor. After these numbers were divided by the length of the given corridor, the more apples-to-apples figure of ridership per mile was considered. These figures revealed a few very high performing corridors, namely Denver's Central corridor, Portland's Central corridor, Denver's Five Points corridor, and Salt Lake City's Central and University corridor, which all achieved an over 5000 riders per mile average. Most lines tended to be clustered in the 1000-3000 average weekday ridership per mile range. The only corridor that did not achieve an average weekday ridership of at least 1000 riders per mile was Salt Lake City's South Jordan corridor.

Ridership growth calculations revealed that a majority of corridors (twelve of the nineteen studied) had experienced ridership decreases in the 2013 to 2017 period. This follows the national trend of many large transit agencies struggling to retain riders in the post-Great Recession period. Despite the existence of ridership declines, no average decline over the period exceeded seven percent. The largest increases in ridership were recorded by airport corridors in each of the three cities. All ridership data are summarized in Table 5.2. 


\begin{tabular}{|c|c|c|c|c|c|c|c|c|c|c|c|c|c|c|c|c|c|c|c|c|}
\hline 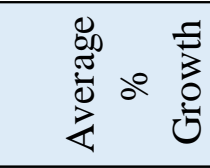 & $\mid \begin{array}{l}0 \\
\sigma^{0} \\
\vdots\end{array}$ & & $\begin{array}{l}0 \\
0 \\
2 \\
0 \\
1\end{array}$ & $\begin{array}{l}0 \\
0 \\
0 \\
0 \\
\dot{0}\end{array}$ & $\begin{array}{l}\dot{f} \\
\dot{f}\end{array}$ & $\begin{array}{l}\frac{0}{a} \\
\vdots \\
\pm\end{array}$ & $\begin{array}{l}0 \\
0 \\
0 \\
1 \\
1\end{array}$ & $\frac{0}{\frac{0}{2}}$ & $\frac{0}{a}$ & $\frac{0}{i n}$ & 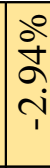 & 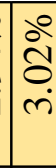 & $\mid \begin{array}{l}0 \\
\infty \\
\\
\tau\end{array}$ & 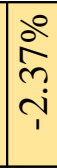 & $\begin{array}{l}0 \\
0 \\
2 \\
\infty \\
0 \\
1\end{array}$ & \begin{tabular}{|c|}
0 \\
0 \\
+ \\
0 \\
0
\end{tabular} & \begin{tabular}{|c|}
0 \\
$\infty$ \\
\multirow{2}{0}{} \\
$\dot{0}$
\end{tabular} & $\begin{array}{l}0 \\
0 \\
6 \\
0 \\
1\end{array}$ & $\left|\begin{array}{l}0 \\
0 \\
\infty \\
m \\
m\end{array}\right|$ & $\begin{array}{l}5 \\
5 \\
0 \\
0 \\
\text { th } \\
0\end{array}$ \\
\hline 氶 & $\begin{array}{l}x^{0} \\
\bar{\sigma} \\
\dot{m}\end{array}$ & $\vec{\nabla}$ & 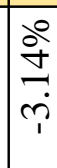 & $\begin{array}{l}\frac{1}{6} \\
\frac{6}{6} \\
\frac{3}{2}\end{array}$ & $\begin{array}{l}\infty \\
\text { N } \\
\infty \\
\infty\end{array}$ & 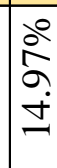 & $\begin{array}{l}0 \\
\infty \\
0 \\
0 \\
1\end{array}$ & 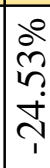 & $\mid \begin{array}{r}0 \\
\infty \\
0 \\
-\end{array}$ & $\begin{array}{l}\infty \\
\infty \\
\infty \\
\infty \\
1\end{array}$ & ? & $\frac{b^{0}}{a}$ & $\begin{array}{l}0 \\
0 \\
0 \\
0 \\
\infty \\
1\end{array}$ & å & $\mid$\begin{tabular}{l|}
0 \\
0 \\
2 \\
$m$ \\
1 \\
1
\end{tabular} & $\begin{array}{l}0 \\
\tilde{m} \\
\end{array}$ & \begin{tabular}{|l|}
0 \\
0 \\
0 \\
0
\end{tabular} & $\mid \begin{array}{c}0 \\
0 \\
\infty \\
\infty \\
i \\
1\end{array}$ & 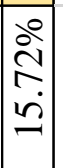 & 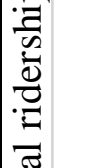 \\
\hline 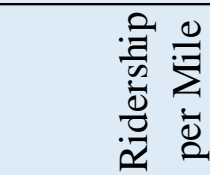 & $\begin{array}{l}\hat{2} \\
\hat{0} \\
\underline{z}\end{array}$ & $\begin{array}{l}\hat{n} \\
\tilde{\sigma}\end{array}$ & @̊ & $\frac{n}{\infty}$ & $\begin{array}{l}\sqrt{n} \\
\infty \\
\infty\end{array}$ & 告 & $\begin{array}{l}8 \\
\text { అூ }\end{array}$ & $\overline{0}$ & 옴 & $\stackrel{m}{ \pm}$ & \begin{tabular}{l}
0 \\
\multirow{2}{N}{} \\
in
\end{tabular} & $\stackrel{ }{2}$ & \begin{tabular}{l}
$\overline{+}$ \\
\multirow{2}{*}{}
\end{tabular} & ○े & $\begin{array}{l}\dot{J} \\
\text { m. } \\
\text { m. }\end{array}$ & $\begin{array}{l}2 \\
\infty \\
\infty \\
\end{array}$ & 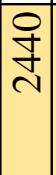 & $\begin{array}{l} \\
0 \\
\text { m } \\
\end{array}$ & $\begin{array}{l} \\
\\
\end{array}$ & 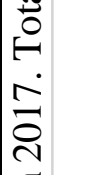 \\
\hline 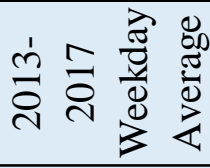 & 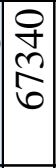 & $\begin{array}{l}\text { No } \\
\text { ర్ }\end{array}$ & 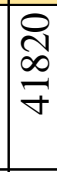 & 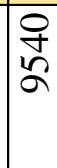 & 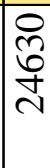 & $\begin{array}{l}\infty \\
\infty \\
\infty \\
\infty \\
m\end{array}$ & $\begin{array}{l}0 \\
0 \\
0 \\
0 \\
0\end{array}$ & $\bar{\Xi}$ & $\underset{N}{\stackrel{N}{N}}$ & 号 & $\begin{array}{l}2 \\
\text { o } \\
\text { g }\end{array}$ & হ & 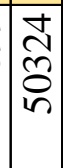 & 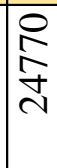 & 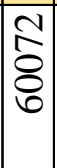 & $\begin{array}{c}0 \\
2 \\
\tilde{m} \\
\end{array}$ & $\begin{array}{l}\tilde{2} \\
\tilde{n} \\
2\end{array}$ & $\begin{array}{l}\vec{N} \\
\infty \\
\sim\end{array}$ & $\begin{array}{l}0 \\
\infty \\
2 \\
1\end{array}$ & 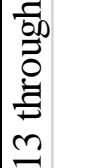 \\
\hline 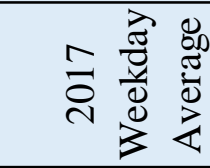 & $\begin{array}{l}\bar{n} \\
\infty \\
6 \\
0\end{array}$ & 合 & $\frac{\hat{n}}{\mathrm{n}}$ & $\begin{array}{l}\bar{n} \\
n \\
\infty\end{array}$ & $\frac{\mathscr{I}}{\mathrm{I}}$ & $\begin{array}{c}\tilde{m} \\
\infty \\
\infty \\
m\end{array}$ & $\begin{array}{l}n \\
n \\
0 \\
0 \\
0\end{array}$ & $\frac{d}{\frac{J}{a}}$ & 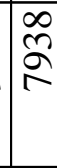 & $\begin{array}{l}\text { f } \\
\text { g }\end{array}$ & 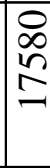 & 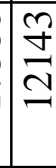 & $\begin{array}{l}1 \\
\infty \\
\infty \\
0 \\
+\end{array}$ & $\begin{array}{l}\infty \\
\infty \\
\sim \\
\sim\end{array}$ & $\begin{array}{c}0 \\
\hat{n} \\
\infty \\
n\end{array}$ & 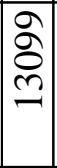 & $\begin{array}{l}\Omega \\
\sigma \\
\sigma \\
\sigma\end{array}$ & 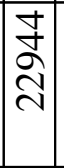 & $\mid \begin{array}{c}0 \\
\text { గ్ర } \\
\infty\end{array}$ & 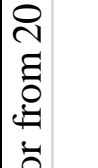 \\
\hline 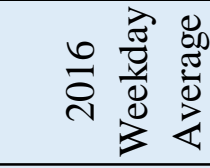 & $\begin{array}{l}7 \\
b \\
0 \\
0 \\
0\end{array}$ & $\frac{\infty}{\sigma}$ & $\frac{\hat{\sigma}}{\dot{y}}$ & ๙2 & $\frac{N}{\sqrt[N]{n}}$ & $\begin{array}{l}\text { f } \\
\text { ma } \\
m\end{array}$ & $\begin{array}{l}\hat{0} \\
\hat{\circ} \\
\hat{\sigma}\end{array}$ & $\begin{array}{l}\text { wे } \\
\infty \\
\sigma\end{array}$ & 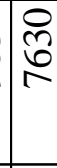 & $\begin{array}{l}8 \\
\text { } \\
\text { nn }\end{array}$ & 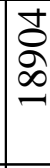 & 弪 & $\begin{array}{l}\overline{\mathbb{N}} \\
\text { à }\end{array}$ & \begin{tabular}{l}
$\mathcal{N}$ \\
\multirow{\infty}{\infty}{} \\
$\mathcal{N}$
\end{tabular} & 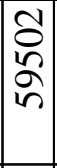 & $\begin{array}{l} \pm \\
m \\
m \\
-\end{array}$ & $\begin{array}{c}0 \\
\hat{n} \\
2\end{array}$ & $\mid \begin{array}{c}\mathbb{v} \\
\hat{2} \\
\text { ה }\end{array}$ & $\mid \begin{array}{c}m \\
\hat{\infty} \\
-1\end{array}$ & 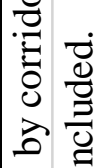 \\
\hline 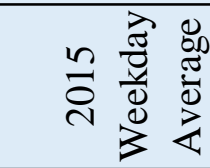 & $\begin{array}{l}\infty \\
0 \\
0 \\
\infty \\
0\end{array}$ & $\hat{2}$ & 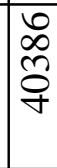 & হু & $\begin{array}{l}\tilde{\Omega} \\
\tilde{n}\end{array}$ & $\mathbb{Z}$ & $\begin{array}{l}\bar{N} \\
\stackrel{N}{\circ} \\
\end{array}$ & $\frac{\infty}{\infty}$ & $\frac{\nabla}{2}$ & $\underset{n}{\stackrel{?}{P}}$ & $\stackrel{\infty}{\infty}$ & $\begin{array}{l}\tilde{n} \\
\tilde{N} \\
\text { तn }\end{array}$ & $\begin{array}{l}7 \\
\\
0 \\
0\end{array}$ & 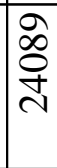 & 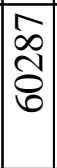 & \begin{tabular}{|c|} 
\\
\multirow{2}{+}{} \\
\end{tabular} & \begin{tabular}{|l|} 
\\
0 \\
1 \\
0 \\
-
\end{tabular} & 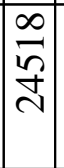 & $\frac{\hat{m}}{\infty}$ & 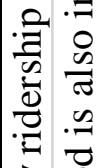 \\
\hline 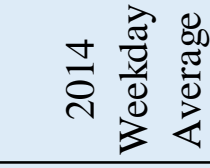 & $\frac{n}{o}$ & $\frac{\infty}{N}$ & 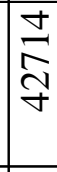 & 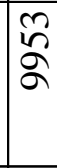 & $\begin{array}{l}8 \\
\stackrel{8}{2} \\
\text { }\end{array}$ & $\mathbb{Z}$ & 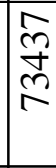 & $\begin{array}{l}0 \\
12 \\
0\end{array}$ & ○ & $\begin{array}{l} \pm \\
\infty \\
n \\
n\end{array}$ & 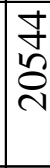 & ป̂ & $\begin{array}{l}N \\
m \\
n \\
n\end{array}$ & 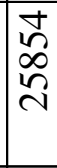 & \begin{tabular}{|l}
$n$ \\
8 \\
$\overline{6}$
\end{tabular} & 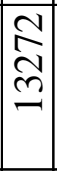 & $\frac{\varangle}{\mathrm{z}}$ & $\begin{array}{l}0 \\
\bar{n} \\
\stackrel{7}{\sim}\end{array}$ & \begin{tabular}{|c|} 
\\
$\infty$ \\
-2
\end{tabular} & 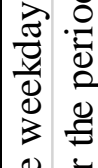 \\
\hline 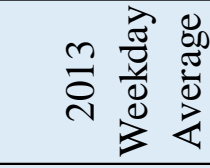 & $\begin{array}{c}\tilde{2} \\
\tilde{v} \\
\tilde{\sigma}\end{array}$ & $\begin{array}{l}n \\
n \\
n \\
n\end{array}$ & 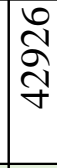 & 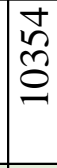 & $\begin{array}{l}\text { à } \\
\text { + } \\
\text { ç }\end{array}$ & $\mathbb{\Delta}$ & $\begin{array}{l}\overline{2} \\
\bar{\sigma}\end{array}$ & 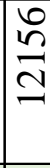 & $\frac{N}{n}$ & \begin{tabular}{l}
8 \\
8 \\
\multirow{1}{*}{}
\end{tabular} & $\begin{array}{l}\infty \\
\infty \\
\infty \\
\infty\end{array}$ & $\begin{array}{l}\mathscr{1} \\
\stackrel{\infty}{0} \\
0\end{array}$ & $\frac{9}{\frac{9}{n}}$ & $\begin{array}{l}\tilde{n} \\
\tilde{n} \\
\text { } \\
\text { na }\end{array}$ & $\begin{array}{l}1 \\
0 \\
0 \\
0\end{array}$ & 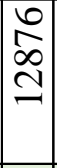 & $\frac{\varangle}{Z}$ & 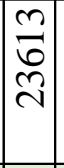 & $\mid$\begin{tabular}{l}
0 \\
\multirow{2}{1}{}
\end{tabular} & 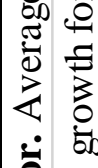 \\
\hline 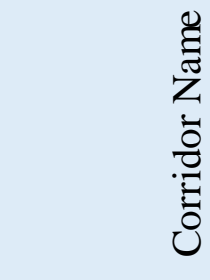 & 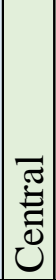 & 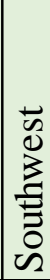 & 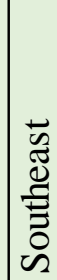 & 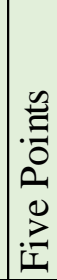 & $\frac{\overrightarrow{\tilde{n}}}{3}$ & : & $\mid \begin{array}{l}\bar{T} \\
\tilde{U} \\
\tilde{U}\end{array}$ & & 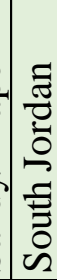 & 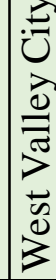 & 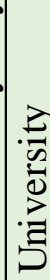 & : & 䄈 & 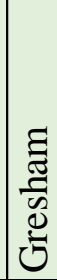 & 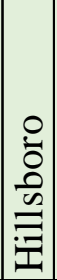 & 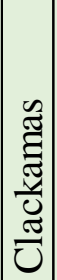 & 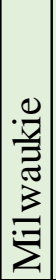 & 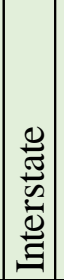 & 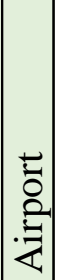 & 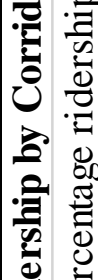 \\
\hline נ] & $\mid$\begin{tabular}{|c}
$\overline{0}$ \\
$\overrightarrow{0}$ \\
$\overline{0}$ \\
0
\end{tabular} & & $\begin{array}{l}\bar{D} \\
\overrightarrow{ \pm} \\
\stackrel{0}{0}\end{array}$ & $\mid \begin{array}{l}\bar{D} \\
\vec{\nu} \\
\overline{0}\end{array}$ & $\mid \begin{array}{l}\bar{D} \\
\bar{d} \\
\overline{0}\end{array}$ & $\mid \begin{array}{l}\bar{D} \\
\bar{D} \\
\bar{D}\end{array}$ & 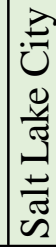 & 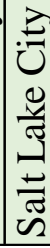 & 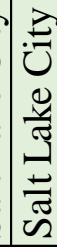 & 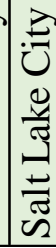 & 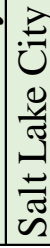 & 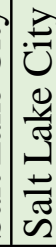 & 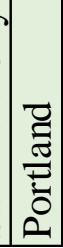 & 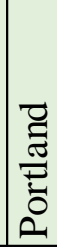 & 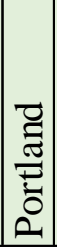 & 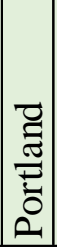 & 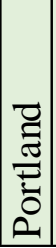 & 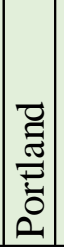 & 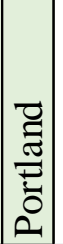 & 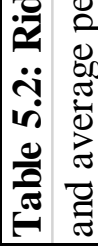 \\
\hline
\end{tabular}


The capital expenditures to construct each corridor experienced a general trend of increase over time, even after inflation was taken into account. This reflects national trends on construction costs outpacing general inflation costs, and in this study may give corridors constructed earlier a distinct performance advantage. Most corridors were constructed at a cost of between $\$ 30$ and $\$ 70$ million per mile, and most of the corridors exceeding this range of per mile costs were in Portland. The recent Milwaukie corridor in Portland shattered all other cost per mile measurements, costing approximately $\$ 200$ million per mile. All capital cost data are summarized in Table 5.3. 


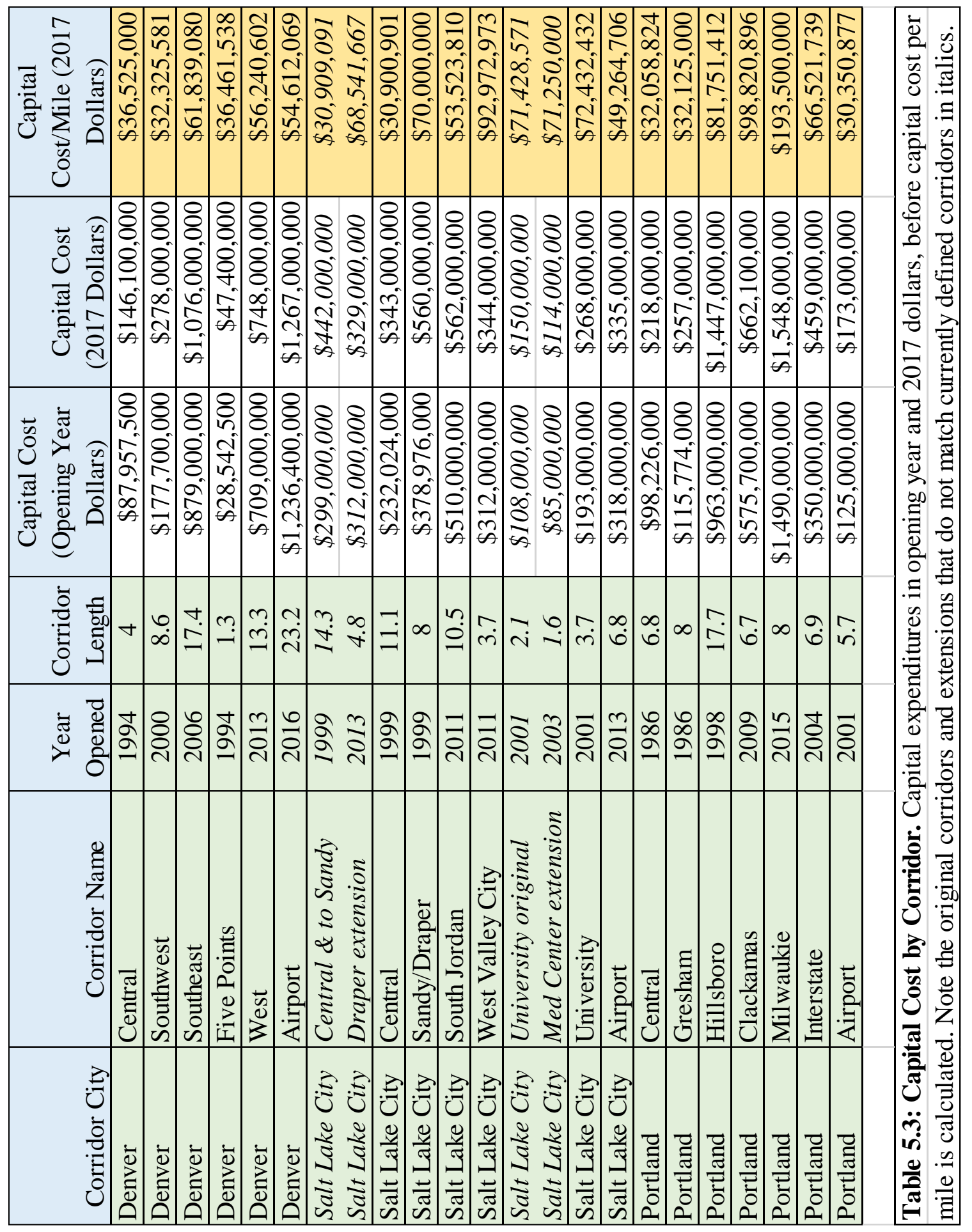


The operating costs provide an approximate measure of the ongoing costs to operate each corridor. Calculated from both service effectiveness metrics provided by the FTA, the cost of operating each corridor is presented as two figures: the operating cost based on operating cost per vehicle mile and the operating cost based on operating cost per vehicle hour. By including both, a more robust measure of true corridor operating costs was made possible. Longer corridors by definition have higher operating costs than shorter ones, so the cost per passenger was used for the performance score.

Operating costs per passenger were highest on the Denver Airport corridor, which is likely due in large part to its use of commuter rail technology rather than light rail technology. Other corridors were fairly clustered in their operating costs, with the cost per passenger based on miles metric usually falling between $\$ 5$ and $\$ 20$, and the cost per passenger based on hours metric usually falling between $\$ 5$ and $\$ 15$. No city appeared to outperform the others on this metric, and no type of corridor (longer or shorter) appeared to dominate either. All operating cost data are summarized in Table 5.4. 


\begin{tabular}{|c|c|c|c|c|c|c|c|c|c|c|c|c|c|c|c|c|c|c|c|c|c|c|c|c|}
\hline 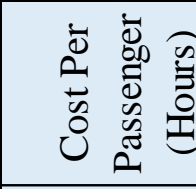 & & & $\frac{0}{0}$ & $\stackrel{0}{0}$ & $\infty$ & $\frac{8}{\sigma}$ & & & 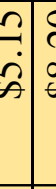 & $\begin{array}{c}\text { N } \\
\infty \\
\infty\end{array}$ & $\begin{array}{l}\vec{f} \\
\dot{ \pm} \\
\dot{\sigma}\end{array}$ & 足 & $\begin{array}{l}\tilde{\sigma} \\
\dot{j} \\
\dot{5}\end{array}$ & 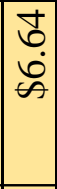 & 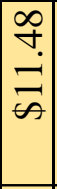 & $\begin{array}{l}\overrightarrow{1} \\
\dot{a} \\
\dot{\infty}\end{array}$ & 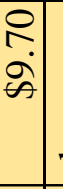 & : & \begin{tabular}{|c|}
$\infty$ \\
$\infty \dot{0}$ \\
$\infty$ \\
$\infty$
\end{tabular} & $\begin{array}{l}\stackrel{9}{m} \\
= \\
=\end{array}$ & \begin{tabular}{|c|} 
\\
1 \\
$\infty$ \\
$\infty$ \\
$\infty$
\end{tabular} & 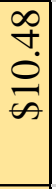 & 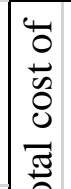 & \\
\hline 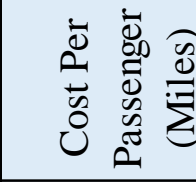 & $\infty$ & $\frac{\infty}{\pi}$ & $\begin{array}{l}\Omega \\
\dot{\infty} \\
\dot{\infty}\end{array}$ & 足 & $\stackrel{2}{\infty}$ & $\frac{7}{\pi}$ & 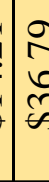 & \begin{tabular}{c|l}
5 \\
$\dot{0}$ \\
0 \\
$n$
\end{tabular} & \begin{tabular}{l|l}
$\vec{b}$ & \\
$\vdots$ & \\
$\omega$ &
\end{tabular} & 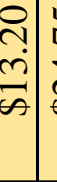 & 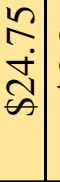 & $\begin{array}{l}0 \\
\infty \\
\infty \\
\infty\end{array}$ & $\mid \begin{array}{l}0 \\
+ \\
\dot{s} \\
\dot{s}\end{array}$ & $\begin{array}{l}0 \\
\infty \\
\infty \\
\infty\end{array}$ & $\begin{array}{c}\infty \\
i \\
i \\
\tilde{\omega} \\
\end{array}$ & $\begin{array}{l}\stackrel{a}{\sigma} \\
\stackrel{i}{\sigma} \\
\dot{s}\end{array}$ & $\begin{array}{l}\sigma \\
\dot{J} \\
\dot{s} \\
\end{array}$ & $\begin{array}{l}0 \\
2 \\
0 \\
0 \\
\tilde{\sigma}\end{array}$ & 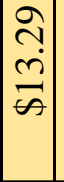 & $\begin{array}{l} \pm \\
\stackrel{ \pm}{*} \\
=\end{array}$ & $\begin{array}{c}\mathcal{N} \\
\infty \\
\infty \\
\infty\end{array}$ & $\frac{\dot{0}}{\infty}$ & $\frac{0}{\frac{0}{0}}$ & 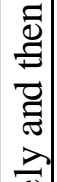 \\
\hline 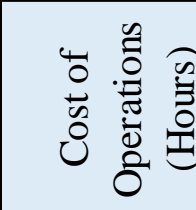 & $\stackrel{m}{\dot{m}}$ & in & 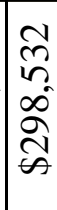 & 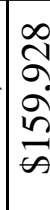 & $\mid \begin{array}{l}\infty \\
\infty \\
\infty \\
\infty\end{array}$ & 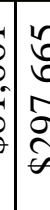 & 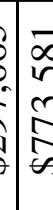 & 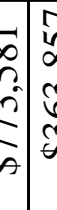 & 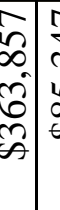 & $\begin{array}{l}4 \\
\text { m } \\
\infty \\
\infty \\
\infty\end{array}$ & 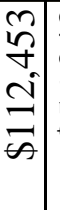 & 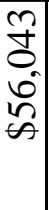 & \begin{tabular}{|l|} 
\\
7 \\
2 \\
$\delta$ \\
$\infty$
\end{tabular} & 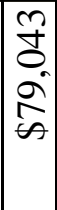 & \begin{tabular}{l|}
1 \\
$\infty$ \\
$\infty$ \\
1 \\
$n$ \\
$n$ \\
$\infty$ \\
\end{tabular} & 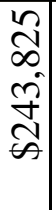 & 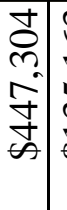 & 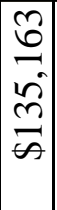 & $\left|\begin{array}{c}0 \\
2 \\
2 \\
\infty \\
0 \\
\infty \\
\infty\end{array}\right|$ & 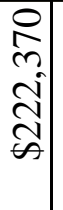 & $\begin{array}{l}0 \\
0 \\
6 \\
\hat{-} \\
\vdots \\
5\end{array}$ & $\begin{array}{l}\hat{\infty} \\
\infty \\
\infty\end{array}$ & $\begin{array}{l}4 \\
0 \\
\tilde{0} \\
0 \\
0 \\
0 \\
.0 \\
0\end{array}$ & . \\
\hline 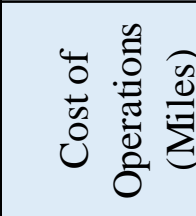 & 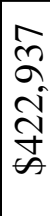 & $\frac{n}{n}$ & 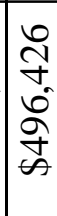 & مَ & $\left\{\begin{array}{l}0 \\
1 \\
\infty \\
\infty \\
n \\
n \\
n\end{array}\right.$ & 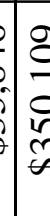 & $\frac{\pi}{2}$ & 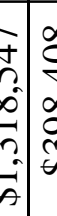 & 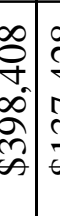 & 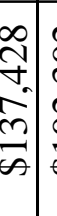 & $\begin{array}{l}\hat{\alpha} \\
\hat{2} \\
\hat{\delta} \\
\tilde{\sigma}\end{array}$ & 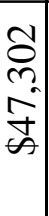 & $\mid \begin{array}{l}1 \\
\beth \\
1 \\
6 \\
\infty\end{array}$ & $\left|\begin{array}{c}2 \\
i n \\
\infty \\
\infty \\
\infty\end{array}\right|$ & 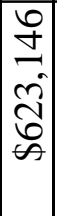 & $\begin{array}{l}\infty \\
n \\
n \\
g \\
\delta \\
\tilde{n} \\
\tilde{n}\end{array}$ & $\begin{array}{l} \\
0 \\
- \\
0 \\
+ \\
0 \\
\infty\end{array}$ & 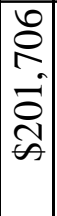 & 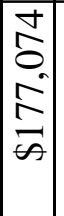 & 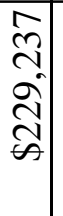 & \begin{tabular}{|l|} 
\\
$\infty$ \\
$\infty$ \\
2 \\
2 \\
$\infty$ \\
$\infty$
\end{tabular} & $\bar{n}$ & 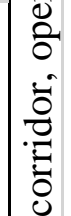 & \\
\hline 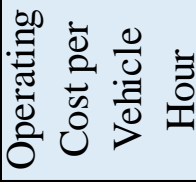 & in & 告 & $\begin{array}{l}n \\
\tilde{8} \\
0 \\
\infty\end{array}$ & 年 & $\begin{array}{l}n \\
0 \\
0\end{array}$ & $\frac{5}{6}$ & $\frac{0}{8}$ & & 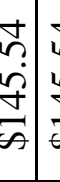 & 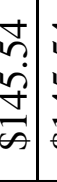 & 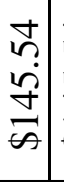 & 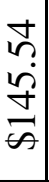 & 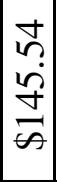 & 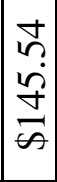 & 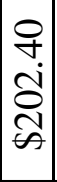 & 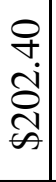 & 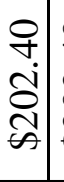 & 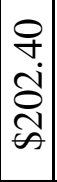 & 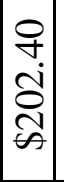 & 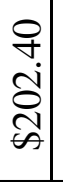 & 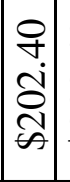 & $\tilde{\infty}$ &.$\Xi$ & \\
\hline 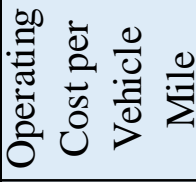 & $\approx$ & 2 & กิ & $\begin{array}{l}\hat{\imath} \\
\hat{\infty}\end{array}$ & $\begin{array}{l}\hat{n} \\
\hat{n}\end{array}$ & 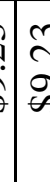 & $\underline{\alpha}$ & & & ల్ల & $\begin{array}{l}\stackrel{\overbrace{}}{1} \\
\infty \\
\infty \\
\infty\end{array}$ & $\begin{array}{l}0 \\
\infty \\
\infty \\
\infty\end{array}$ & 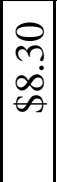 & $\mid \begin{array}{l}0 \\
\infty \\
\infty \\
\infty \\
\infty\end{array}$ & $\begin{array}{l}\bar{\sigma} \\
\dot{\sigma} \\
\bar{\omega}\end{array}$ & $\begin{array}{l}\bar{a} \\
\dot{\omega} \\
\bar{\infty}\end{array}$ & $\begin{array}{l}\bar{\sigma} \\
\dot{\sigma} \\
\bar{s}\end{array}$ & $\begin{array}{l}\bar{\sigma} \\
\dot{\sigma} \\
\bar{\omega}\end{array}$ & $\left|\begin{array}{l}\bar{\sigma} \\
\dot{\omega} \\
\bar{\infty}\end{array}\right|$ & $\begin{array}{l}\bar{\sigma} \\
\dot{\omega}\end{array}$ & $\left|\begin{array}{l}\bar{\sigma} \\
\bar{\sigma} \\
\bar{s}\end{array}\right|$ & $\frac{m}{\omega}$ & $\begin{array}{l}\frac{1}{0} \\
\frac{2}{2}\end{array}$ & \\
\hline 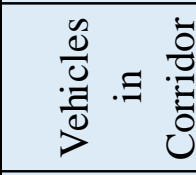 & $\overline{8}$ & $\begin{array}{l}\infty \\
\text { } \\
\text { ñ }\end{array}$ & $\begin{array}{l}+ \\
\text { ๙ } \\
\text { m }\end{array}$ & $\begin{array}{l}\infty \\
\infty \\
\curvearrowright \\
\text { సి }\end{array}$ & $\frac{J}{N}$ & $\tilde{c}$ & 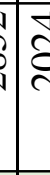 & & 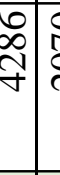 & 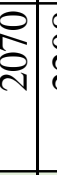 & 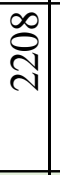 & 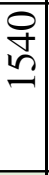 & $\frac{n}{\sim}$ & $\begin{array}{l}\sqrt{n} \\
n \\
-\end{array}$ & \begin{tabular}{|l|}
$\infty$ \\
$\infty$ \\
2 \\
6 \\
\end{tabular} & \begin{tabular}{l}
$\stackrel{\circ}{\infty}$ \\
\multirow{2}{N}{}
\end{tabular} & 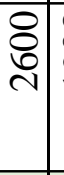 & \begin{tabular}{|l|}
$\infty$ \\
0 \\
0
\end{tabular} & $\begin{array}{l} \\
8 \\
9\end{array}$ & 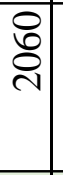 & 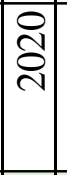 & 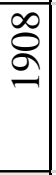 & $\begin{array}{c}z \\
\dot{\theta}\end{array}$ & \\
\hline$\overline{0}$ & $\underset{\exists}{\pi}$ & 苍 & 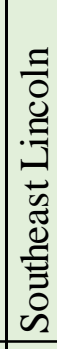 & 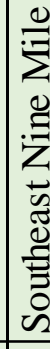 & 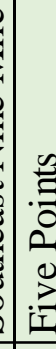 & 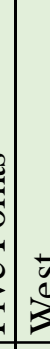 & 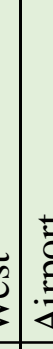 & : & 苞 & $\frac{\sqrt{3}}{2}$ & 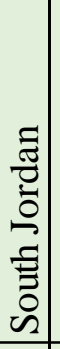 & $\begin{array}{l}\bar{\pi} \\
\bar{z} \\
\bar{n} \\
\overline{0} \\
3\end{array}$ & 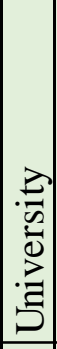 & \begin{tabular}{|l}
0 \\
0 \\
0 \\
0 \\
\end{tabular} & 莞 & 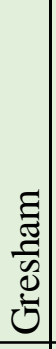 & $\begin{array}{l}0 \\
0 \\
0 \\
0 \\
= \\
=\end{array}$ & 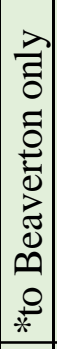 & 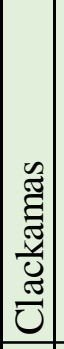 & 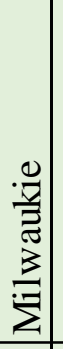 & 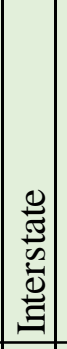 & & 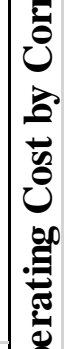 & \\
\hline 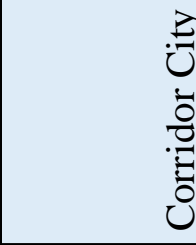 & & $\bar{\nu}$ & $\begin{array}{l}\overline{0} \\
\overrightarrow{0} \\
\overline{0}\end{array}$ & $\stackrel{\overline{0}}{\overline{0}}$ & 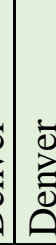 & a & 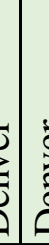 & 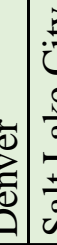 & 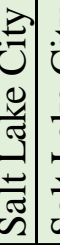 & \pm & 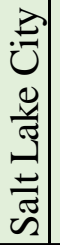 & $\stackrel{0}{3}$ & 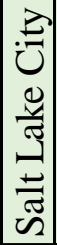 & 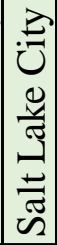 & 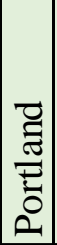 & 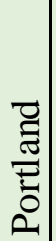 & 胥 & 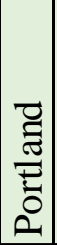 & 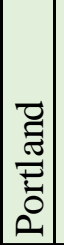 & 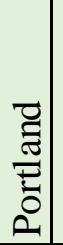 & 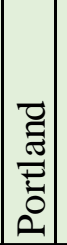 & 胥 & in & \\
\hline
\end{tabular}


To compare these raw figures for ridership, capital cost, and operating cost, a zscore was created for each of the five quantitative inputs. The cumulative area under the z-score normal curve was then used to build an index of 0-100 created for each input, with 100 being the high score and 0 being the low. Based on the weightings outlined in the previous chapter, a final performance score was constructed, and corridors were ranked 1-19 based on their performance score. These rankings are available in Table 5.5.

The Central corridors in Denver and Salt Lake City led the way, followed closely by the Denver Five Points, Salt Lake City University, and Portland Central corridors. Most corridors were clustered close to middle with a score closer to 50, which makes logical sense given that the performance score is a relative and not an absolute index. Some of the lower performing corridors were the West Valley City corridor in Salt Lake City and Milwaukie corridor in Portland, trailed by the Denver Airport and Salt Lake City South Jordan corridors rounding out the bottom of the list.

These performance scores were broken down into ridership and financial performance subscores, which generally reflected the overall performance scores. However, there were some notable exceptions. The Denver Central, Denver Airport Portland Central, and Portland Milwaukie corridors had disproportionally high ridership compared to their general performance, and the Denver Southwest, Salt Lake City Airport, Portland Gresham, and Salt Lake City Sandy/Draper corridors had disproportionally low ridership. Accordingly, these corridors also had disproportionally low and high financial scores, respectively. These examples highlight the importance of 
how performance is measured, as weightings that give more weight to ridership or more weight to financials will rank corridors differently than this study has ranked them.

None of the three cities in this study had consistently higher or lower performing corridors compared to the others. Although Salt Lake City was home to three of the six lowest performing corridors, it is also home to three of the six highest performing. Denver and Portland each had a fair number of high, medium, and lower performing corridors. Because these corridors were compared exclusively to each other and not to any national averages of ridership per mile, capital costs per mile, etc., the performance score does not necessarily carry any meaning on a wider scale. For example, corridors in these three cities may be performing well above or well below the national average for urban rail transit lines, but this was not tested here. 


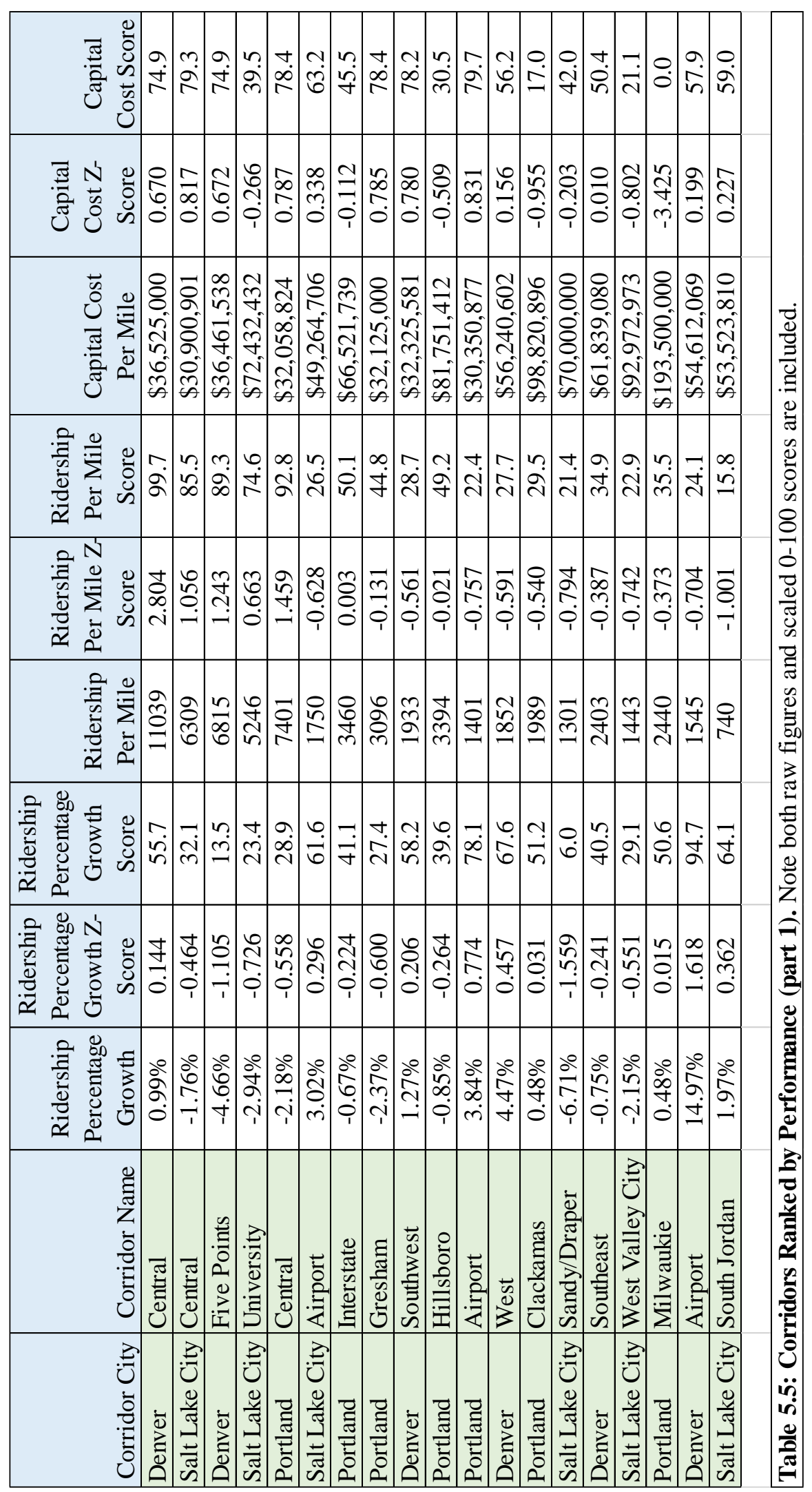




\begin{tabular}{|c|c|c|c|c|c|c|c|c|c|c|c|c|c|c|c|c|c|c|c|c|}
\hline 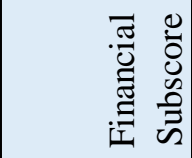 & $\stackrel{n}{r}$ & ‡゙ & $\begin{array}{l}\infty \\
\stackrel{\infty}{\gamma}\end{array}$ & r & $\begin{array}{l}0 \\
\text { in } \\
\text { nf }\end{array}$ & $\stackrel{\infty}{r}$ & ָู & ב & $\stackrel{+}{\text { in }}$ & 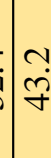 & $\stackrel{?}{q}$ & $\begin{array}{l}m \\
\ddot{v}\end{array}$ & $\begin{array}{c}-\dot{\sim} \\
\dot{\gamma}\end{array}$ & n? & $\begin{array}{l}\infty \\
\text { m. }\end{array}$ & 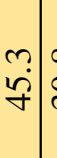 & \begin{tabular}{l}
$\infty$ \\
\hdashline \\
$m$
\end{tabular} & 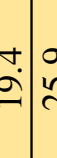 & $\begin{array}{l}a \\
a \\
a\end{array}$ & \\
\hline 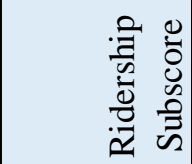 & 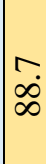 & $\stackrel{\mathrm{N}}{\mathrm{N}}$ & $\stackrel{n}{?}$ & $\frac{\infty}{\sigma}$ & ف & $\begin{array}{l}n \\
\sim \\
m\end{array}$ & Э઼ & ?ִ & 뭉 & $\mid \begin{array}{l}\infty \\
\dot{0}\end{array}$ & 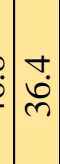 & $\hat{\tilde{n}}$ & वे & n & $\begin{array}{l}\text { ?ొ: } \\
\text { me }\end{array}$ & ¿ே & ని & $\frac{0}{7}$ & $\frac{a}{2}$ & \\
\hline 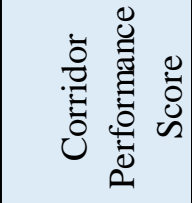 & $\underset{\infty}{\ddot{\infty}}$ & $\stackrel{n}{2}$ & $\stackrel{0}{r}$ & ळ. & تี & $\begin{array}{l}+ \\
\infty \\
\infty\end{array}$ & $\begin{array}{l}n \\
\stackrel{0}{n}\end{array}$ & $\begin{array}{l}\infty \\
\text { in } \\
\text { n. }\end{array}$ & $\begin{array}{l}9 \\
7\end{array}$ & f & $\stackrel{\square}{\dot{g}}$ & $\begin{array}{l}0 \\
\\
\end{array}$ & $\begin{array}{l}0 \\
\\
\end{array}$ & बें & $\begin{array}{c}N \\
\end{array}$ & m. & $\begin{array}{c}\stackrel{c}{\dagger} \\
\stackrel{m}{m}\end{array}$ & 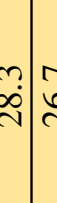 & نे & $\mid \begin{array}{l}0 \\
0 \\
0 \\
0 \\
0 \\
.0 \\
0 \\
0\end{array}$ \\
\hline 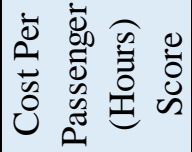 & సं & ஜ̊ & ป & न & $\vec{m}$ & 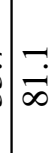 & ㅇ. & $\stackrel{\infty}{\stackrel{\infty}{n}}$ & $\stackrel{+}{\stackrel{+}{n}}$ & $: \stackrel{+}{i}$ & $\begin{array}{lll} & 0 \\
\dot{j} & \dot{f}\end{array}$ & $\begin{array}{c}0 \\
\infty \\
\sim \\
\sim\end{array}$ & $\left|\begin{array}{c}0 \\
\infty \\
0 \\
0\end{array}\right|$ & $\mid \begin{array}{l}\infty \\
\sigma \\
\sigma\end{array}$ & \begin{tabular}{l|l}
$a$ & 0 \\
$\infty$ & \\
$m$ &
\end{tabular} & $\begin{array}{l}\infty \\
\dot{\gamma} \\
\dot{\gamma}\end{array}$ & $\begin{array}{l}0 \\
\dot{m}\end{array}$ & 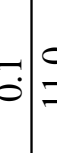 & $\underline{0}$ & $\mid \begin{array}{l}0 \\
0 \\
\vdots \\
0 \\
0 \\
0 \\
0\end{array}$ \\
\hline 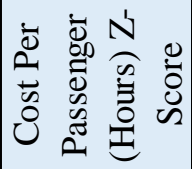 & å & ઼ָ & $\begin{array}{l}n \\
0 \\
n \\
0\end{array}$ & ?n & $\begin{array}{l}\bar{\gamma} \\
\stackrel{+}{0} \\
\dot{1}\end{array}$ & $\begin{array}{l}\infty \\
\infty \\
0\end{array}$ & 尹ं & 옹 & $\frac{8}{\circ}$ & $\stackrel{2}{2}$ & $\begin{array}{l}n \\
\dot{n} \\
\dot{0} \\
\end{array}$ & $\mid \begin{array}{c}m \\
\infty \\
n \\
0 \\
1\end{array}$ & $\left|\begin{array}{l}\infty \\
0 \\
0 \\
0 \\
0\end{array}\right|$ & $\mid \begin{array}{c}\sigma \\
\delta \\
+ \\
0 \\
0\end{array}$ & 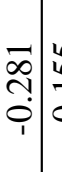 & $\begin{array}{l}n \\
n \\
0 \\
\end{array}$ & $\begin{array}{ll}0 & \\
\text { ले } \\
\text { ஸे }\end{array}$ & $\begin{array}{c}\vec{m} \\
\dot{m} \\
\dot{m}\end{array}$ & 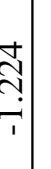 & 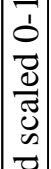 \\
\hline 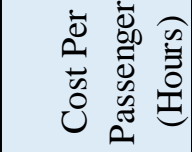 & ?̊ & $\frac{n}{n}$ & $\begin{array}{l}\infty \\
n \\
\infty \\
\infty\end{array}$ & ๙ૅ & $\stackrel{\infty}{\underset{+}{\sigma}}$ & $\begin{array}{l}\vec{b} \\
0 \\
0\end{array}$ & $\begin{array}{l}\infty \\
\sim \\
\infty \\
\infty\end{array}$ & $\begin{array}{l}+ \\
\infty \\
\infty\end{array}$ & 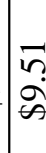 & \& & 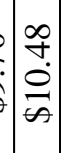 & 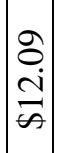 & $\left|\begin{array}{c}\infty \\
\dot{\infty} \\
\infty \\
\infty\end{array}\right|$ & 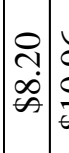 & 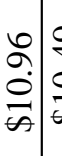 & $\begin{array}{l}a \\
\dot{0} \\
\dot{\sigma}\end{array}$ & 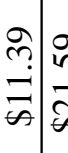 & $\frac{5}{2}$ & 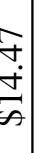 & 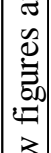 \\
\hline 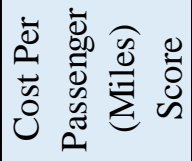 & $\frac{0}{\infty}$ & $\ddot{\infty}$ & $\begin{array}{l}\infty \\
\infty \\
\infty\end{array}$ & $\begin{array}{l}0 \\
\infty\end{array}$ & $\begin{array}{l}0 \\
\dot{+}\end{array}$ & ז & $\underset{⿱}{ \pm}$ & تُ & 元 & : & 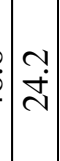 & $\mid \begin{array}{l}0 \\
\dot{y} \\
\gamma\end{array}$ & \begin{tabular}{l}
$N$ \\
\hdashline \\
\end{tabular} & $\left|\begin{array}{l}0 \\
\dot{0} \\
n\end{array}\right|$ & $\begin{array}{ll}0 \\
\stackrel{+}{d}\end{array}$ & $\rightleftarrows$ & $\begin{array}{l}\infty \\
\text { n } \\
\end{array}$ & \begin{tabular}{l|l}
$n$ \\
\hdashline \\
\end{tabular} & & $\mid \begin{array}{l}5 \\
0 \\
0 \\
0 \\
0 \\
0 \\
7\end{array}$ \\
\hline 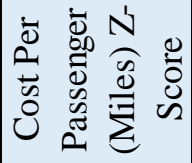 & $\hat{\alpha}$ & ڤ̊ & a & Nָ & ב & $\underset{\sim}{\stackrel{I}{+}}$ & テै & $\frac{\dot{J}}{0}$ & $\begin{array}{l}\infty \\
0 \\
0 \\
0\end{array}$ & $\begin{array}{l}0 \\
\infty \\
0 \\
0 \\
1\end{array}$ & $\mid \begin{array}{c}8 \\
\stackrel{8}{2} \\
\vdots \\
\vdots \\
1\end{array}$ & $\begin{array}{l}= \\
\bar{Z} \\
0 \\
1\end{array}$ & 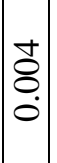 & $\begin{array}{l}n \\
0 \\
0 \\
0\end{array}$ & $\begin{array}{l}0 \\
\stackrel{2}{0} \\
\dot{0}\end{array}$ & $\begin{array}{l}0 \\
n \\
n \\
0\end{array}$ & $\frac{\hat{\sigma}}{\dot{0}} \mid \hat{\delta}$ & 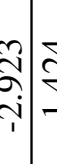 & 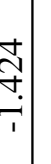 & 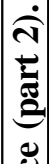 \\
\hline 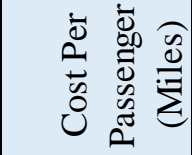 & 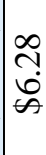 & 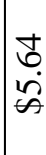 & $\begin{array}{l}\stackrel{2}{r} \\
\dot{\sigma}\end{array}$ & $\begin{array}{l}0 \\
\dot{y} \\
\dot{\omega}\end{array}$ & 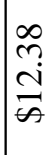 & $\begin{array}{l}0 \\
\tilde{s} \\
\tilde{n}\end{array}$ & $\stackrel{ }{\infty}$ & $\frac{g}{\text { वे }}$ & $\infty$ & 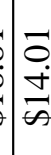 & $\mid \begin{array}{l}5 \\
\infty \\
\infty \\
\infty\end{array}$ & $\begin{array}{l}\tilde{y} \\
\dot{J} \\
\dot{s}\end{array}$ & 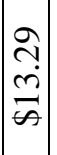 & 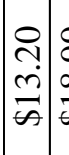 & \begin{tabular}{l|l}
$\sigma$ & \\
$\infty$ & 0 \\
$\infty$ &
\end{tabular} & \begin{tabular}{l|l} 
& \\
$\infty$ & \\
$\infty$ & \\
$\infty$ &
\end{tabular} & 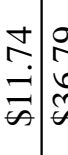 & 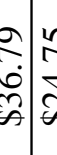 & 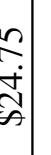 & 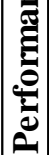 \\
\hline 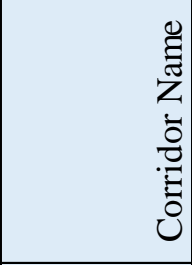 & 苞 & 苞 & 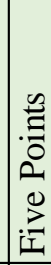 & 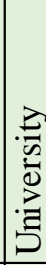 & 胥 & 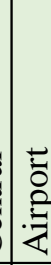 & 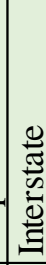 & 胥 & $\begin{array}{l}0 \\
0 \\
z \\
\vdots \\
0 \\
\tilde{z}\end{array}$ & 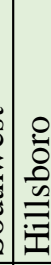 & 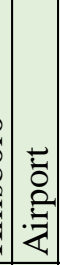 & $\vec{z}$ & 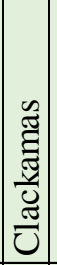 & 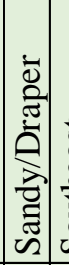 & 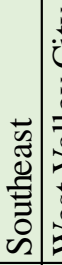 & 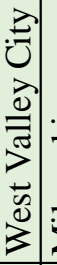 & 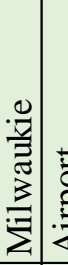 & 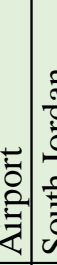 & 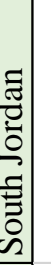 & 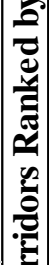 \\
\hline 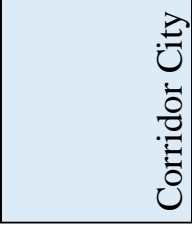 & ڤ্ঠ & 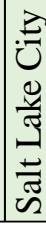 & 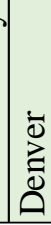 & 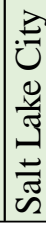 & 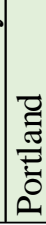 & 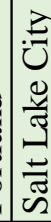 & 总 & 总 & $\begin{array}{l}\bar{\circlearrowright} \\
\grave{\Xi}\end{array}$ & 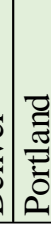 & 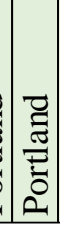 & $\begin{array}{l}\bar{\Xi} \\
\grave{\Xi} \\
\bar{\Xi} \\
\end{array}$ & 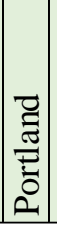 & 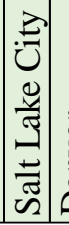 & 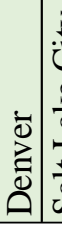 & 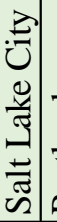 & 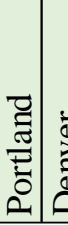 & 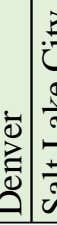 & 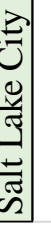 & 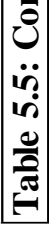 \\
\hline
\end{tabular}




\subsection{Performance and Corridor Characteristics}

The performance score for each corridor was then compared with its corridor characteristics. In terms of neighborhood factors, population densities within the corridors ranged from approximately 4000 to 12,000 per square mile, median income from about $\$ 35,000$ to $\$ 76,000$, percentage renter occupied from 27 to 74 percent, percent in the labor force from 65 to 76 percent, job density from 1300 to 49,900 per square mile, and walkability from 28 to 91 . In terms of transit, the average number of park and ride spaces per station within the corridors ranged from zero to over 500, the average number of bus route connections per station from less than one to almost seven, the average headways between trains from approximately four to approximately seventeen minutes, and the average train speed from eight to 38 miles per hour.

These corridor characteristics measures were kept in their original form for analysis and regression testing. These characteristics are summarized in Table 5.6. 


\begin{tabular}{|c|c|c|c|c|c|c|c|c|c|c|c|c|c|c|c|c|c|c|c|c|}
\hline 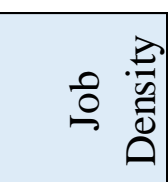 & 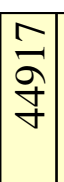 & \begin{tabular}{|l|}
\multirow{2}{*}{} \\
$\stackrel{n}{7}$ \\
ma
\end{tabular} & $\begin{array}{l}\infty \\
\infty \\
\infty\end{array}$ & $\begin{array}{l} \\
\\
\end{array}$ & 京 & $\frac{\tilde{\infty}}{\sigma}$ & $\vec{N}$ & 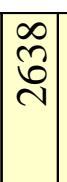 & 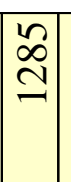 & \begin{tabular}{|l|}
$\infty$ \\
6 \\
6 \\
$\infty$
\end{tabular} \mid & $\begin{array}{c}N \\
\tilde{n} \\
\infty\end{array}$ & 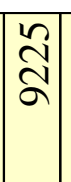 & $\begin{array}{l}2 \\
2 \\
2\end{array}$ & $\frac{a}{2}$ & \begin{tabular}{l}
$m$ \\
\multirow{2}{*}{} \\
$n$
\end{tabular} & $\frac{1}{n}$ & \begin{tabular}{|l}
$\hat{\alpha}$ \\
$\hat{n}$
\end{tabular} & 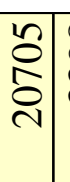 & $\begin{array}{l}\infty \\
\text { m } \\
\text { m. }\end{array}$ & \\
\hline 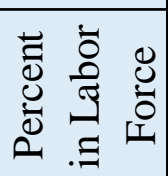 & $\begin{array}{l}0 \\
\dot{r}\end{array}$ & F & $\begin{array}{l}0 \\
\text { i } \\
\end{array}$ & $\begin{array}{l}n \\
r \\
r\end{array}$ & $\begin{array}{l}0 \\
\dot{0} \\
\end{array}$ & $\begin{array}{l}n \\
\hat{\sigma} \\
\end{array}$ & $\begin{array}{l}9 \\
0 \\
0\end{array}$ & $\hat{\imath}$ & $\begin{array}{l} \\
\text { m} \\
\end{array}$ & - & $\begin{array}{l}n \\
0 \\
6\end{array}$ & \begin{tabular}{|l|}
$\infty$ \\
$\dot{\sigma}$ \\
\end{tabular} & \begin{tabular}{l|}
9 \\
$\infty$ \\
0
\end{tabular} \mid & ri & $\begin{array}{l}1 \\
0 \\
0 \\
0\end{array}$ & $\sqrt[6]{6}$ & \begin{tabular}{|c|}
0 \\
6 \\
6
\end{tabular} & $\stackrel{9}{0}$ & $\begin{array}{l}+ \\
6 \\
6\end{array}$ & 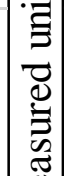 \\
\hline 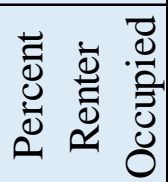 & $\begin{array}{l}0 \\
\dot{0}\end{array}$ & $\begin{array}{r}\dot{f} \\
\end{array}$ & \begin{tabular}{|l|}
$\infty$ \\
$\dot{0}$ \\
+
\end{tabular} & $\begin{array}{l}\infty \\
\dot{0}\end{array}$ & $\begin{array}{l}n \\
6 \\
\end{array}$ & $\begin{array}{l}\text { c1 } \\
\text { ñ. }\end{array}$ & $\overrightarrow{\dot{U}}$ & mे & $\begin{array}{l}m \\
\\
\end{array}$ & \begin{tabular}{|c|}
0 \\
$\infty$ \\
+ \\
\end{tabular} & $\begin{array}{l}\sigma \\
\dot{\gamma}\end{array}$ & \begin{tabular}{|c|}
$n$ \\
$n$ \\
6
\end{tabular} & $\begin{array}{l}0 \\
i \\
n \\
n\end{array}$ & $\begin{array}{c}0 \\
\dot{n} \\
n\end{array}$ & \begin{tabular}{|c|}
$n$ \\
$\infty$ \\
$n$ \\
$n$
\end{tabular} & $\frac{m}{n}$ & \begin{tabular}{|c|}
$n$ \\
$n$ \\
$n$ \\
$n$
\end{tabular} & 官 & $\begin{array}{l}n \\
? \\
y\end{array}$ & $\begin{array}{l}. \Xi \\
.0 \\
.0\end{array}$ \\
\hline 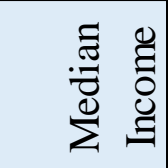 & 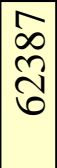 & $\begin{array}{l}\infty \\
\infty \\
\tilde{\sigma} \\
\sigma\end{array}$ & 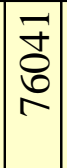 & $\begin{array}{l}a \\
\underset{7}{7} \\
\dot{n}\end{array}$ & 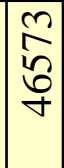 & 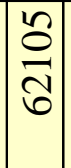 & 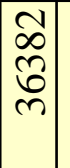 & \begin{tabular}{|l|}
$\overline{0}$ \\
0 \\
0 \\
0
\end{tabular} & 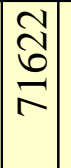 & \begin{tabular}{|c|}
$\tilde{n}$ \\
$\hat{\theta}$ \\
$y$
\end{tabular} & 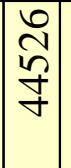 & \begin{tabular}{|l|}
8 \\
\\
8 \\
8 \\
8 \\
\end{tabular} & 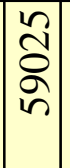 & 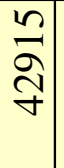 & $\begin{array}{l}n \\
n \\
n \\
n\end{array}$ & 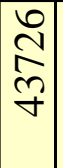 & \begin{tabular}{|l|}
$\infty$ \\
$i n$ \\
$\infty$ \\
$\infty$ \\
$n$ \\
$n$
\end{tabular} & $\begin{array}{l}n \\
n \\
\circ \\
n\end{array}$ & $\underset{\mathbb{N}}{\stackrel{N}{f}}$ & 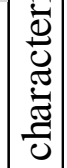 \\
\hline 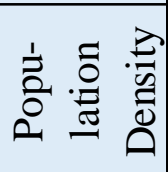 & $\begin{array}{l}0 \\
0 \\
\infty \\
\infty\end{array}$ & $\frac{\nabla}{\nabla}$ & $\frac{6}{n}$ & $\begin{array}{l}0 \\
6 \\
=\end{array}$ & \begin{tabular}{|l|} 
\\
$\infty$ \\
$\infty$ \\
\end{tabular} & $\begin{array}{l}\bar{\infty} \\
n \\
n\end{array}$ & \begin{tabular}{|l|} 
\\
$n$ \\
$\delta$ \\
0
\end{tabular} & \begin{tabular}{|l|} 
\\
\\
0 \\
+
\end{tabular} & 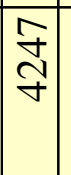 & \begin{tabular}{l|} 
\\
$\infty$ \\
$\infty$ \\
$n$ \\
\end{tabular} & \begin{tabular}{c|}
0 \\
+ \\
$\infty$ \\
$\infty$
\end{tabular} & $\begin{array}{l} \\
0 \\
0 \\
\end{array}$ & $\begin{array}{l}n \\
0 \\
0\end{array}$ & $\begin{array}{l}\hat{\mathfrak{o}} \\
\text { Na }\end{array}$ & 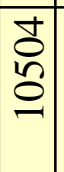 & 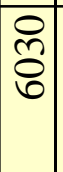 & \begin{tabular}{|l|} 
\\
$\infty$ \\
0 \\
0 \\
\end{tabular} & 告 & $\begin{array}{l}\stackrel{\infty}{\sim} \\
\underset{\forall}{\forall}\end{array}$ & 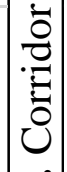 \\
\hline 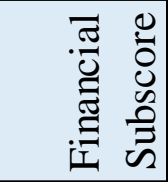 & $\begin{array}{c}0 \\
\dot{N} \\
\end{array}$ & $\begin{array}{l}m \\
\tilde{ \pm} \\
n\end{array}$ & $\begin{array}{c}n \\
\tilde{\sigma} \\
\dot{f}\end{array}$ & $\stackrel{+}{\nabla}$ & $\mid \begin{array}{l}\vec{\forall} \\
\dot{+}\end{array}$ & $\begin{array}{c}\Upsilon \\
\infty \\
\infty\end{array} \mid$ & $\left|\begin{array}{l}0 \\
0 \\
0\end{array}\right|$ & 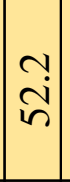 & $\begin{array}{l}n \\
n \\
n\end{array} \mid$ & $\left|\begin{array}{l}\infty \\
0 \\
\dot{\sigma}\end{array}\right|$ & $\left|\begin{array}{l}\infty \\
6 \\
6\end{array}\right|$ & $-\frac{1}{6}$ & $\left|\begin{array}{c}N \\
\infty \\
n\end{array}\right|$ & $\left|\begin{array}{l}\infty \\
\dot{8}\end{array}\right|$ & $\begin{array}{l}0 \\
\dot{8} \\
\dot{\gamma}\end{array}$ & $\underset{f}{g}$ & $\mid \begin{array}{l}0 \\
\dot{d} \\
m\end{array}$ & $\begin{array}{l}n \\
\infty \\
n\end{array}$ & $\vec{n}$ & 预 \\
\hline 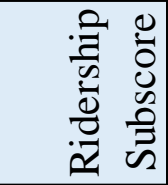 & $\stackrel{\vec{\infty}}{\infty}$ & $\mid \begin{array}{l}\infty \\
\dot{+} \\
m\end{array}$ & m. & 2. & $\frac{a}{m}$ & $\left|\begin{array}{c}\nabla \\
\infty \\
m\end{array}\right|$ & $\begin{array}{l}9 \\
\hat{2}\end{array}$ & $\begin{array}{c}7 \\
\infty\end{array}$ & $\begin{array}{l}\Omega \\
\tilde{N}\end{array}$ & $\begin{array}{l}n \\
n \\
\sim\end{array}$ & $\left|\begin{array}{l}0 \\
\dot{b}\end{array}\right|$ & $\left|\begin{array}{c}0 \\
\text { n. } \\
\text { ma }\end{array}\right|$ & $\left|\begin{array}{l}\infty \\
\dot{\square} \\
\infty\end{array}\right|$ & $\stackrel{\sim}{\stackrel{\sim}{f}}$ & $\begin{array}{l}\infty \\
\dot{\gamma} \\
\forall\end{array}$ & $\begin{array}{l}\dot{\nabla} \\
\dot{\vec{m}}\end{array}$ & $\left|\begin{array}{c}n \\
2 \\
m\end{array}\right|$ & $\stackrel{\sim}{\infty}$ & $\stackrel{m}{m}$ & 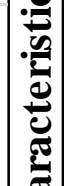 \\
\hline 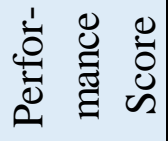 & 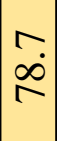 & $\mid \begin{array}{l}n \\
\vdots \\
+\end{array}$ & $\begin{array}{l}0 \\
\dot{\gamma} \\
\end{array}$ & $\stackrel{r}{\dot{T}}$ & $\begin{array}{l}\mathcal{N} \\
\dot{f}\end{array}$ & $\begin{array}{l}n \\
\vdots \\
\end{array} \mid$ & $\therefore$ & $\left|\begin{array}{c}0 \\
\infty \\
m\end{array}\right|$ & ? & $\left|\begin{array}{c}r \\
\infty \\
\infty\end{array}\right|$ & 周 & $\begin{array}{l}m \\
\dot{n}\end{array}$ & $\left|\begin{array}{l}\infty \\
\infty \\
0 \\
0\end{array}\right|$ & $\left|\begin{array}{c}0 \\
\hat{n} \\
n\end{array}\right|$ & $\begin{array}{l}n \\
0 \\
\dot{\gamma}\end{array}$ & $\begin{array}{l}n \\
\dot{q} \\
\dot{q}\end{array}$ & $\left|\begin{array}{l}n \\
0 \\
n \\
n\end{array}\right|$ & $\stackrel{\nabla}{n}$ & $\begin{array}{l}\infty \\
\dot{f}\end{array}$ & 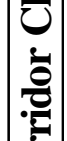 \\
\hline 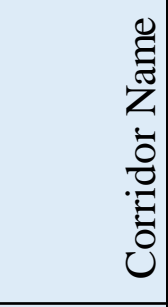 & 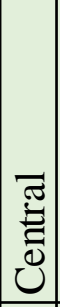 & 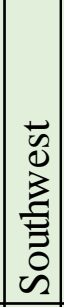 & 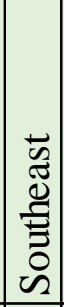 & \begin{tabular}{|c|}
$\cdot$ \\
0 \\
0 \\
0 \\
0 \\
0 \\
$\vdots$ \\
0 \\
\end{tabular} & $\begin{array}{l}\overrightarrow{0} \\
\vec{z}\end{array}$ & : & 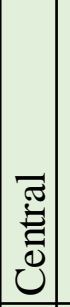 & 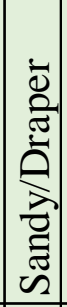 & 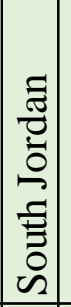 & 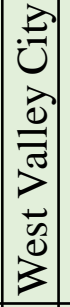 & 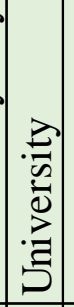 & 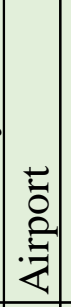 & 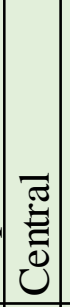 & 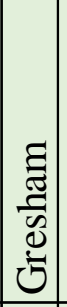 & $\begin{array}{l}0 \\
0 \\
0 \\
0 \\
0 \\
\vdots \\
\\
\end{array}$ & 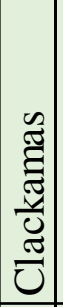 & 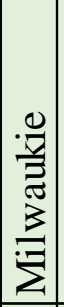 & 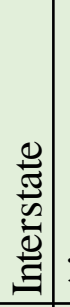 & 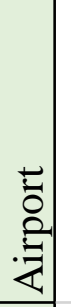 & 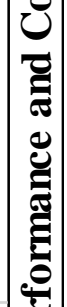 \\
\hline 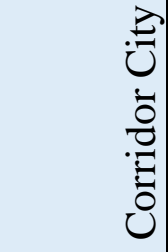 & 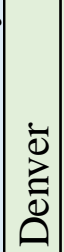 & 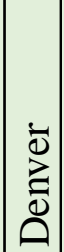 & $\mid \begin{array}{l}\overline{0} \\
\grave{D} \\
\overline{0} \\
0\end{array}$ & $\mid \begin{array}{l}\overline{0} \\
\grave{D} \\
\bar{D}\end{array}$ & $\mid \begin{array}{l}\overline{0} \\
\overrightarrow{0} \\
\overline{0} \\
0\end{array}$ & $\left|\begin{array}{c}\overline{0} \\
\grave{\Xi} \\
\overline{\bar{D}} \\
0\end{array}\right|$ & 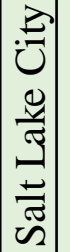 & 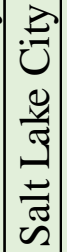 & 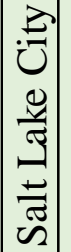 & 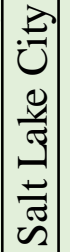 & 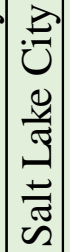 & 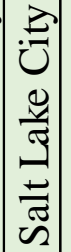 & 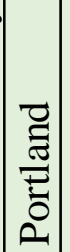 & 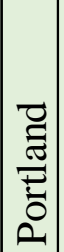 & 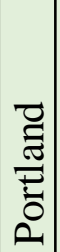 & 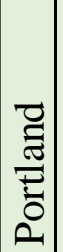 & 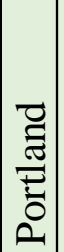 & . & 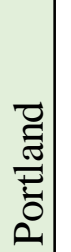 & 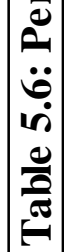 \\
\hline
\end{tabular}




\begin{tabular}{|c|c|c|c|c|c|c|c|c|c|c|c|c|c|c|c|c|c|c|c|c|}
\hline 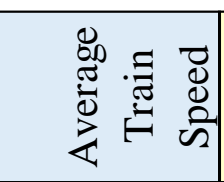 & $\begin{array}{l}\infty \\
0 \\
0\end{array}$ & $\begin{array}{l}\overrightarrow{\dot{D}} \\
\dot{\mathrm{d}}\end{array}$ & \begin{tabular}{|c|}
$n$ \\
0 \\
$m$ \\
\end{tabular} & \begin{tabular}{|l}
0 \\
\end{tabular} & 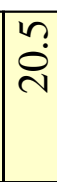 & \begin{tabular}{|l|}
0 \\
$\dot{m}$
\end{tabular} & $\stackrel{n}{a}$ & 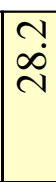 & 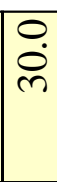 & $\begin{array}{l}\infty \\
\dot{J} \\
\end{array}$ & $\stackrel{n}{\stackrel{n}{c}}$ & $\stackrel{+}{\stackrel{0}{\sigma}}$ & in & $\begin{array}{l}n \\
\infty \\
\infty \\
0\end{array}$ & $\begin{array}{l}\infty \\
\dot{0} \\
\end{array}$ & $\begin{array}{l}0 \\
\dot{0} \\
\tilde{c}\end{array}$ & \begin{tabular}{|c|}
0 \\
$i$ \\
-1
\end{tabular} & $\begin{array}{l}m \\
\dot{I}\end{array}$ & 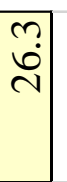 & s] \\
\hline 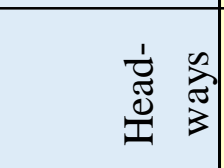 & $\overrightarrow{+}+\vec{f}$ & $\begin{array}{l}\infty \\
0 \\
0\end{array}$ & $\begin{array}{l}0 \\
0 \\
0\end{array}$ & \begin{tabular}{|c}
0 \\
$i$ \\
-
\end{tabular} & $\begin{array}{l}0 \\
\stackrel{2}{2}\end{array}$ & $\begin{array}{l}0 \\
i \\
-1\end{array}$ & $\infty$ & 舟 & 番 & 舟 & 舟 & 番 & ?ִ & $\begin{array}{l}n \\
\\
\end{array}$ & $\begin{array}{l}0 \\
0 \\
0\end{array}$ & $\begin{array}{c}0 \\
i \\
-1\end{array}$ & $\stackrel{n}{\simeq}$ & $\begin{array}{l}0 \\
\text { in }\end{array}$ & $\begin{array}{l}0 \\
\qquad \\
\square\end{array}$ & 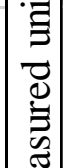 \\
\hline ص & \begin{tabular}{|c|}
$\sim$ \\
$m$ \\
\end{tabular} & $\begin{array}{l}\infty \\
\dot{m}\end{array}$ & $\begin{array}{l}\sim \\
\sim \\
\end{array}$ & $\tilde{0}$ & $\vec{m}$ & \begin{tabular}{|l|}
0 \\
$\dot{0}$
\end{tabular} & $\stackrel{+}{i}$ & $\infty$ & $\stackrel{+}{-}$ & $\begin{array}{l}\infty \\
i \\
\sim\end{array}$ & $\dot{m}$ & $\begin{array}{l}0 \\
i\end{array}$ & $\begin{array}{l}\infty \\
i \\
\sim\end{array}$ & \begin{tabular}{|l|}
0 \\
\end{tabular} & $\begin{array}{l}0 \\
\text { in }\end{array}$ & $\stackrel{?}{\sim}$ & $\vec{m}$ & 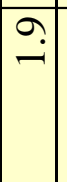 & $\stackrel{0}{-}$ & $\begin{array}{l}. \Xi \\
0 \\
0 \\
\Xi\end{array}$ \\
\hline 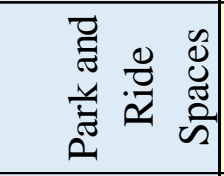 & 2 & $\frac{a}{n}$ & $\begin{array}{l}8 \\
8 \\
\text { ம }\end{array}$ & $n$ & $\frac{t}{m}$ & $\overrightarrow{7}$ & $\overline{0}$ & $\underset{m}{\forall}$ & $\frac{\infty}{n}$ & â & 0 & 0 & nี & $\stackrel{n}{2}$ & O & $\begin{array}{l}\infty \\
\infty \\
\sim\end{array}$ & $\begin{array}{l}\infty \\
\infty \\
\end{array}$ & $\mathscr{q}$ & 䎹 & 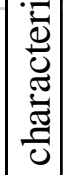 \\
\hline 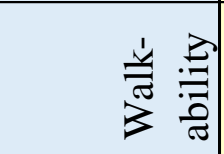 & 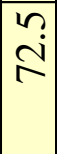 & $\begin{array}{l}\infty \\
\dot{\sigma} \\
\dot{0}\end{array}$ & $\begin{array}{l}m \\
\dot{n}\end{array}$ & $\dot{8}$ & in & $\begin{array}{l}\mathfrak{r} \\
\mathfrak{f}\end{array}$ & $\begin{array}{l}0 \\
6 \\
\end{array}$ & $\begin{array}{l}n \\
q \\
\gamma\end{array}$ & $\vec{\infty}$ & $\begin{array}{l}n \\
\dot{8} \\
n\end{array}$ & $\begin{array}{l}0 \\
0 \\
0\end{array}$ & $\begin{array}{l}0 \\
6 \\
0\end{array}$ & $\frac{1}{\infty}$ & $\begin{array}{c}N \\
i \\
N\end{array}$ & $\begin{array}{l}n \\
6 \\
6\end{array}$ & $\begin{array}{l}n \\
\tilde{\sigma} \\
\end{array}$ & \begin{tabular}{l}
+ \\
\multirow{2}{*}{}
\end{tabular} & $\begin{array}{l}\hat{q} \\
\dot{r}\end{array}$ & $\begin{array}{l}\infty \\
\dot{\delta} \\
\dot{y}\end{array}$ & 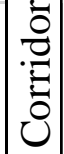 \\
\hline 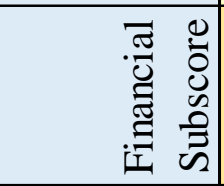 & 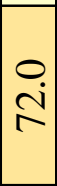 & $\begin{array}{l}m \\
\dot{n}\end{array}$ & $\begin{array}{l}n \\
\dot{q}\end{array}$ & $\frac{\nabla}{\sim}$ & $\begin{array}{l}+ \\
\stackrel{\infty}{+}\end{array}$ & $\begin{array}{c}\sim \\
\infty\end{array}$ & $\begin{array}{l}0 \\
0 \\
0\end{array}$ & $\begin{array}{l}\tilde{N} \\
\tilde{N}\end{array}$ & $\begin{array}{l}n \\
m \\
m\end{array}$ & $\begin{array}{l}\infty \\
\dot{0} \\
+\end{array}$ & $\begin{array}{l}\infty \\
6 \\
\sigma\end{array}$ & $\frac{1}{6}$ & $\begin{array}{l}1 \\
\infty \\
n\end{array}$ & $\left|\begin{array}{l}\infty \\
\dot{8}\end{array}\right|$ & $\begin{array}{l}0 \\
\dot{f} \\
\gamma\end{array}$ & $\underset{f}{f}$ & $\begin{array}{l}0 \\
\dot{1}\end{array}$ & $\left|\begin{array}{c}0 \\
\infty \\
n\end{array}\right|$ & ஸें & $\underbrace{N}_{0}$ \\
\hline 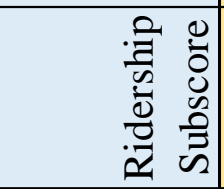 & $\begin{array}{l}\hat{\infty} \\
\infty\end{array}$ & $\begin{array}{l}\infty \\
\dot{+}\end{array}$ & $\frac{m}{m}$ & $\stackrel{2}{2}$ & $\frac{a}{m}$ & $\begin{array}{c}\nabla \\
\infty \\
m\end{array} \mid$ & $\frac{a}{1}$ & $\stackrel{\infty}{\infty}$ & त̃ & $\begin{array}{l}m \\
\tilde{n}\end{array}$ & $\begin{array}{l}9 \\
\dot{0}\end{array}$ & $\begin{array}{c}0 \\
\dot{n} \\
\text { rn }\end{array}$ & $\begin{array}{l}\infty \\
\dot{+}\end{array}$ & $\stackrel{\vec{v}}{\stackrel{\gamma}{q}}$ & \begin{tabular}{l}
$\infty$ \\
\multirow{\gamma}{\gamma}{}
\end{tabular} & $\begin{array}{l}+ \\
\stackrel{+}{+}\end{array}$ & 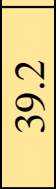 & $\mid \begin{array}{c}0 \\
\infty \\
\dot{\gamma}\end{array}$ & $\begin{array}{c}\text { m. } \\
\text { m. }\end{array}$ & 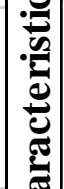 \\
\hline 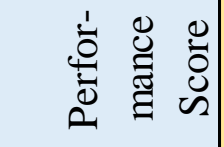 & $\frac{r}{\infty}$ & $\begin{array}{l}n \\
\text { in } \\
+\end{array}$ & $\begin{array}{l}0 \\
\dot{\gamma}\end{array}$ & $\frac{r}{J}$ & $\begin{array}{l}\stackrel{N}{8} \\
\dot{J}\end{array}$ & $\begin{array}{l}n \\
\dot{0} \\
\text { va }\end{array}$ & $\stackrel{2}{2}$ & $\begin{array}{l}0 \\
\infty \\
m\end{array}$ & n̊. & $\begin{array}{c}N \\
\infty \\
m\end{array}$ & ชூ & 古 & $\begin{array}{l}\infty \\
\infty \\
0\end{array}$ & $\left|\begin{array}{c}0 \\
\hat{n} \\
n\end{array}\right|$ & $\begin{array}{l}n \\
0 \\
y\end{array}$ & $\begin{array}{l}m \\
0 \\
\dot{y}\end{array}$ & $\begin{array}{l}n \\
\text { ñ }\end{array}$ & in & $\begin{array}{l}\infty \\
\dot{g}\end{array}$ & : \\
\hline 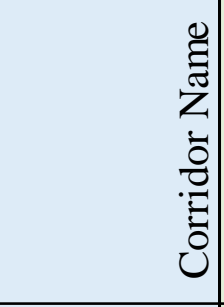 & 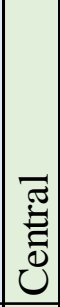 & 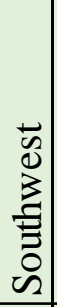 & 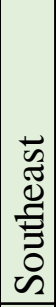 & \begin{tabular}{|c|c}
0 \\
0 \\
0 \\
2 \\
0 \\
0 \\
0 \\
0
\end{tabular} & $\begin{array}{l}\overline{0} \\
\dot{z}\end{array}$ & 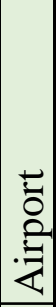 & U & 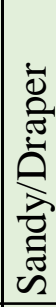 & 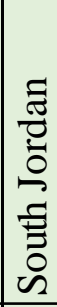 & 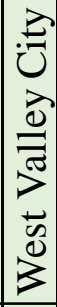 & 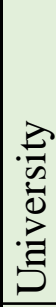 & 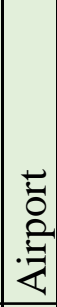 & 胥 & 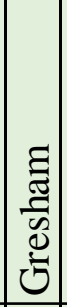 & $\begin{array}{l}0 \\
0 \\
0 \\
0 \\
0 \\
\vdots \\
\vdots \\
\end{array}$ & \begin{tabular}{|l}
$\tilde{z}$ \\
$\tilde{\Xi}$ \\
$\tilde{z}$ \\
$\tilde{z}$ \\
$\tilde{\Xi}$ \\
$\tilde{U}$ \\
\end{tabular} & 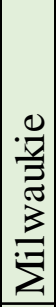 & 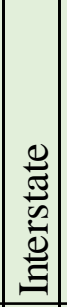 & : & 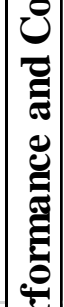 \\
\hline 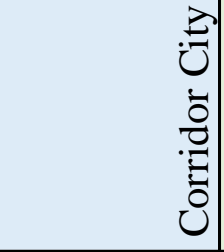 & $\begin{array}{l}\overline{0} \\
\grave{D} \\
\bar{D}\end{array}$ & $\begin{array}{l}\dot{\overline{0}} \\
\stackrel{\bar{\Delta}}{\bar{\Delta}}\end{array}$ & \begin{tabular}{|l}
$\overline{0}$ \\
$\grave{\Delta}$ \\
$\overline{0}$ \\
0
\end{tabular} & $\begin{array}{l}\dot{0} \\
\geq \\
\overline{0} \\
0 \\
0\end{array}$ & $\begin{array}{l}\overline{0} \\
\grave{D} \\
\overline{0}\end{array}$ & \begin{tabular}{|c}
$\overline{0}$ \\
$\grave{\Delta}$ \\
$\overline{0}$ \\
0
\end{tabular} & 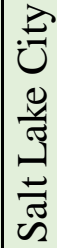 & 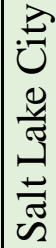 & 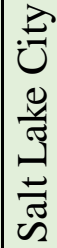 & 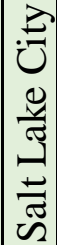 & 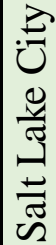 & 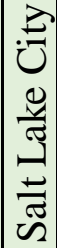 & 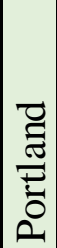 & 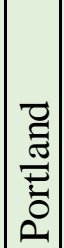 & 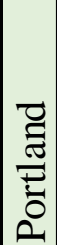 & 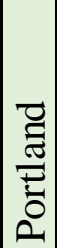 & 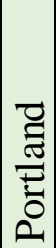 & 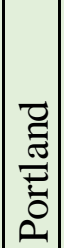 & 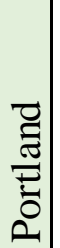 & 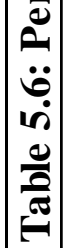 \\
\hline
\end{tabular}


Regression testing revealed that a great deal of the performance of each corridor can be explained by variations in the corridor characteristics. The first test run comparing the overall performance score with the potential explanatory variables had an R-squared value of 0.879 , meaning that 87.9 percent of the variability in each corridor's performance score can be explained by variability in its corridor characteristics. However, no independent variable was found to have a p-value of less than 0.05 .

To determine which factors did play a role in determining performance, a correlation matrix was constructed using corridor characteristics as independent variables and the three performance scores as dependent variables. Regression tests were also run individually between each of the ten independent variables and three dependent variables to test whether a statistically significant relationship existed.

Higher population density, higher percentage of renter occupied units, higher job density, higher walkability, a lower number of park and ride spaces, lower headways between trains, and lower average train speed were all found to be significant predictors of a higher overall performance score. All of those except a lower number of park and ride spaces were found to be predictors of a higher ridership performance subscore as well. A lower median income, higher percentage of renter occupied units, higher walkability, a lower number of park and ride spaces, and lower average train speed were found to be predictors of a higher financial performance subscore. The correlation matrix output is provided in Table 5.7. 


\begin{tabular}{|c|c|c|c|}
\hline Correlation Matrix & Performance & Ridership Sub & Financial Sub \\
\hline Performance Score & 1 & & \\
\hline Ridership Subscore & 0.858296926 & 1 & \\
\hline Financial Subscore & 0.934553598 & 0.61953302 & 1 \\
\hline Population Density & 0.517049184 & 0.605688189 & 0.370943653 \\
\hline Median Income & -0.362172818 & -0.094258694 & -0.488656358 \\
\hline Percentage Renter Occupied & 0.71321349 & 0.676306198 & 0.622049364 \\
\hline Percent in Labor Force & 0.102926103 & 0.103733537 & 0.085516829 \\
\hline Job Density & 0.579330881 & 0.737125592 & 0.375076784 \\
\hline Walkability & 0.66309579 & 0.635521643 & 0.573664487 \\
\hline Park and Ride Spaces & -0.603156521 & -0.454105461 & -0.607770033 \\
\hline Bus Route Connections & -0.17144404 & 0.079735679 & -0.317546913 \\
\hline Headways & -0.490628752 & -0.690708882 & -0.271574671 \\
\hline Average Train Speed & -0.62284507 & -0.509865247 & -0.599223566 \\
\hline
\end{tabular}

Table 5.7: Regression Analysis Results. The R values for each correlation are shown above. Those found to have significant relationships $(\mathrm{p}<0.05)$ are highlighted in green.

Finally, a measure of variability of performance scores between the three cities studied was considered. Since the performance score index is a relative index, it is not surprising that the overall mean score was 50.3. The mean performance scores for Denver and Salt Lake City were 51.5, while Portland's was slightly lower at 48.2. The difference was not found to be statistically significant using a difference of means test. The standard deviation of the performance scores was much higher in Denver and Salt Lake City than in Portland, suggesting there may be greater variability in the performance of corridors in Denver and Salt Lake City and more uniform performance of corridors in Portland.

However, this difference was not found to be statistically significant using an F-test for difference of variances. These results are shown in Table 5.8. 


\begin{tabular}{|l|c|c|c|c|}
\cline { 2 - 5 } Performance Score Variability & Overall & Denver & Salt Lake City & Portland \\
\hline Mean & 50.3 & 51.5 & 51.5 & 48.2 \\
\hline Standard Deviation & 16.8905 & 21.7713 & 20.4724 & 10.1683 \\
\hline
\end{tabular}

Table 5.8: Variability Between Cities. The mean performance scores for each city and the standard deviations of the performance scores are shown here.

\subsection{Interviews}

Results from the six interviews conducted are primarily discussed in the following chapter, but a few major points are addressed here. None of the interviewees expressed substantive objections to the performance criteria used to define success at the corridor level. The only suggestion some of them noted was that including additional criteria, such as enhanced accessibility to jobs, a measure to capture new transit oriented development (TOD) investments, or other ways to measure changes taking place in each corridor, would make the performance metric stronger. However, the interviewees also admitted that finding comparable metrics to measure these would be difficult to come by, especially when including more than one city.

Interviewees were generally not surprised by the rankings given to each corridor in their city, as it often fell in line with what they already believed were the stronger and weaker performers. One noted concern was how the metric may appear to favor shorter corridors over longer ones because of its emphasis on operating costs. Since operating rail transit over longer distances becomes more expensive, unless the trains are consistently as full as they are on shorter corridors, longer corridors will appear more expensive. Interviewees were also not generally surprised by the corridor characteristics 
found to be correlated with performance. The strong influence of headways and density are generally known to be important factors in transit planning. 


\section{CHAPTER 6: DISCUSSION}

This chapter integrates the results from the quantitative and qualitative data gathered in this study, and discusses the similarities and differences between them. This approach provides a more nuanced perspective of corridor performance and the multiple factors involved than would have been possible if only one set of methods was used.

\subsection{Interview Insights from Denver}

Both interviewees in Denver agreed that the Southeast and Southwest corridors were high performers in the region, with the Central corridor also seen as doing well. The high ranking of the Five Points corridor was seen as a surprise, but the lower ranking of the West line was less surprising. One interviewee noted how RTD bus services were continually adjusted to meet changing travel demands as these corridors opened and changed transit dynamics, and how some of the Southeast corridor's platforms had to be retrofitted to fit four car trains because of higher than anticipated ridership. Somewhat similarly, park and ride lots on the Southwest corridor were often full, suggesting higher than expected utilization of the originally planned infrastructure.

Factors seen as important for strong corridor performance noted by the interviewees included the frequency of service, density measures for both population and employment, and having activity centers at both ends of a corridor (e.g., having the 
Denver Tech Center at the other end of the Southeast corridor from downtown, or the airport at the end of that corridor), and having parking available for potential riders. The importance of parking costs at the destination end of trips (usually downtown) was also brought up as being important in driving ridership, although the interviewee who made that suggestion was unsure of a reasonable metric to use since the cost of parking is complicated, not only by differing hourly and daily rates but also by employers who subsidize parking costs for their employees.

The two Denver interviewees were also in agreement in noting the importance of taking an active role in coalition building (often of businesses and major employers in each corridor) as part of successful corridor development. One emphasized that simply having the funds to move forward is not the end-all, be-all, noting that how the contracts are written is important for the designing, building, and operating processes. The other noted how tradeoffs are often necessary, such as weighing the potential benefits and consequences of whether public-private partnerships should be used for a project, with a recognition that there is never going to be a completely perfect planning process. One area in which the interviewees differed was in the importance of TOD and land use planning, with one believing in a very active process to accompany corridor development, while the other said these types of planning were only "sort of" important.

An interesting point was raised by one interviewee who said that each corridor opened in the Denver region has developed something of a personality of its own, dependent on factors like how many stops there are, how frequent and how fast the trains 
travel, and the unique geography of each corridor. This is what can make comparing lines like the Southeast and West corridors so difficult. Even if this is undoubtedly true in some senses, simply saying that each corridor will develop a personality of its own once it is publicly funded and built is not a strong argument in favor of future development. Thus, even if the process of quantifying and standardizing differences between corridors can be messy, it is still necessary to compare peers as part of the process of better understanding performance.

\subsection{Interview Insights from Salt Lake City}

The interviewees in Salt Lake City were in agreement that the largest impetus for initial development of light rail in the city was the 2002 Olympics. In terms of present day performance, both agreed that the Central corridor running south from downtown, often referred to as the "spine," was the largest success. One believed the University corridor to be the best performing, with the caveat that University of Utah faculty and students get free transit passes that are undoubtedly partially responsible for its strong ridership. The noted success factors of headways and population density made sense to the interviewees.

There was also agreement about how the spine following the higher density I-15 corridor was especially successful, but that corridors moving away from that spine have had to contend with lower densities, like the West Valley City and South Jordan corridors. One interviewee noted that the Airport corridor had also been seen as a success, not only for linking the airport to downtown, but also for serving the lower 
income communities on the way to the airport. As in Denver, the idea that shorter corridors like the University corridor may be somewhat favored in this methodology was noted by one of the interviewees.

An interesting point was raised regarding how success should be measured during one of the interviews. While the interviewee was unsurprised by the corridor rankings, he also suggested that if corridor success was measured by the amount of land use change it induced, the South Jordan corridor would be at the top of the list and the Central corridor would be much lower. Seeing light rail systems as a means of connecting existing activity centers and reducing congestion is a different proposition from seeing them as a way to spur new patterns of development, with the latter usually requiring a much longer time horizon to be realized. The other interviewee said they were not surprised by the South Jordan corridor's last place ranking given the low density development around the line and the large new housing development at the line's end that is not yet fully completed.

The recognition that light rail can provide a service beyond just generating ridership is understood in Salt Lake City. One interviewee noted how UTA is developing an Access to Opportunity metric that will quantify measures such as how many more jobs are now accessible to captive transit riders than before service was available. Thus, providing people with not only access to places, but also giving them more choices in their lives is a recognized goal in addition to ridership figures. Both interviewees also noted the importance of having multiple activity centers along a corridor, so that it can have more uses than just one directional commuting. Identifying places where activities 
are clustered is currently being worked on by UTA and the regional council of governments.

Having a strong feeder bus system and park and ride options available were noted as important factors of success by interviewees in Salt Lake City. The central spine has a long established system whereby east-west buses connect to the light rail line for easy north-south connections, but corridors off of the spine do not have the same robust feeder bus connections. Even though park and rides have been an important part of the equation, one interviewee noted that the biggest surprise has been how many more people are simply walking to light rail stations than originally anticipated.

According to both interviewees, an important factor UTA has had to address in the development of its transit corridors has been the zoning policies in the municipalities the lines pass through. If current zoning does not allow for higher density or mixed use developments in station areas, it will be far more difficult to create TOD zones that can function as activity centers. Cities and their policies need to be in line with these transit goals to ensure success, which has not always been the case in some surrounding suburbs that are not interested in up-zoning.

Some final takeaways noted by one interviewee included building light rail where there already are people and jobs, and not just building where it is easiest because land is available. Getting out ahead of development and securing the right of way early has been crucial. Additionally, just hoping for development is a poor strategy; instead, working with governments to make sure appropriate zoning policies are in place that give people a 
real reason to ride transit is the most important. The other interviewee stressed the importance of time scale when it comes to measuring success, because two years might not be long enough to see the effect of transit-induced development, but would see ridership that reflected the current level of development in the corridor. Being able to understand the nuances in measures of success was thus emphasized.

\subsection{Interview Insights from Portland}

Performance in Portland was seen as strong by the interviewees for almost all corridors. One interviewee said that the Central, Gresham, and Hillsboro corridors are the best performers, in part due to their routes paralleling a major congested highway corridor, with the other lines filling in the gaps before the interviewee saw the Clackamas corridor at the bottom. The other interviewee also noted the struggles of the Clackamas corridor, but believed the Interstate corridor may be the highest performer followed by the Central and Gresham lines. Noted factors in driving success in the interviewees' eyes included both population and job density, and the perception that making the same trip in a car would be inconvenient, a somewhat difficult to quantify metric.

Both interviewees discussed the important role that the choice of right of way has played in the success of Portland's system, since it in part determines what kind of development can take place along the corridor. A decision was made to run the Interstate corridor along a city street rather than the I-5 expressway in hopes that it would be better utilized by neighborhood residents. It was a resounding success. In contrast, the decision to run the Clackamas corridor along the I-205 expressway instead of down a street 
median has been seen as a weak point, since the corridor can feel disconnected from the neighborhoods it is meant to serve.

Gentrification was also mentioned by both of the interviewees multiple times as an issue driving the current public discourse in Portland, and how light rail can be seen as a factor in increasing housing prices in the region. Developing new corridors through low income areas would likely meet resistance from those neighborhoods which fear rising rents. Gentrification also impacts potential funding more in Portland than it does in other cities. Since Oregon has no sales tax, other sources of revenue must be found to fund corridor development. Increasing property taxes is an option, but it could potentially hurt homeowners who are already struggling with mortgage payments.

Developing a relationship with the region's business community was also brought up by one interviewee as an important factor in building a successful light rail system. Having Nike and Intel onboard was important in driving the Hillsboro corridor forward, and in opening the Airport corridor. Demonstrating the value added and direct benefits to people is important in forging these relationships; for example, giving Nike the option to put their employees bound for the airport on a train in Beaverton. The interviewee also suggested that forging relationships with transportation networking companies like Uber and Lyft will grow increasingly important in the future, since finding ways to effectively partner with them is preferable to competing with them for riders.

The other interviewee spoke more about the inherent challenges of capturing the services that light rail provides for the region that defy simple measurement, much like 
the attempt to create an Access to Opportunity metric in Salt Lake City. As Portland continues to grow, the question of whether light rail can direct some of its growth to places that will eliminate car trips has become an important consideration, even if it is very difficult to quantify. Despite this difficulty, it will be important in both environmental terms and in creating TOD and higher density communities.

A final consideration for moving forward that both of the interviewees highlighted was how the share of funding provided by New Starts and other federal programs has steadily decreased with each new corridor built. While the original Central and Gresham corridor was 83 percent federally funded, that decreased to 73 percent for the Hillsboro corridor, 72 percent for the Clackamas corridor, and only 50 percent for the Milwaukie corridor. TriMet's currently planned corridor running south from downtown Portland to Tualatin is hoping for another 50 percent match, but given the project's high cost, identifying local funds sufficient to cover the remaining 50 percent will be a challenge.

\subsection{Major Themes}

Many of the points raised in these interviews were recurring across different cities, suggesting the importance of their inclusion in the development of effective light rail systems. Building partnerships with the business community in the region, particularly with major employers in these rail transit corridors, was discussed in both the Denver and Portland interviews. Seeing these corridors as projects that need to cater to already existing employment and residential patterns rather than to expect businesses and 
housing developments to follow them is important if achieving high ridership is the goal. Thus, developing these partnerships with the already existing players in each corridor and asking what they would like to see should not be overlooked.

In a similar vein, ensuring local municipalities are on board with corridor development plans is important as well. The importance of TOD planning, planning for changes in land use, and having appropriate zoning codes in place for transit cannot be overlooked if corridors are to be successful, as was brought up in Denver and Salt Lake City. Selecting an appropriate right of way for the project was also brought up repeatedly, as choosing a corridor route where there is already travel demand will be more likely to succeed than choosing a route that may be more convenient but misses major activity centers.

In each of the three cities, there was some initial suspicion that light rail transit investments would be a boondoggle or have negative effects on the surrounding bucolic suburbs. However, as noted by interviewees, these initial concerns generally evaporated once the first line or two opened and the conversation instead shifted to when light rail would reach their own corner of the metro area. Even once political support grew, challenges still remained in the contracting and financing realms, which led to publicprivate partnerships in Denver, or reduced frequency of some bus routes in Salt Lake City as more UTA funds were needed for light rail operations.

Another major theme specifically regarded how performance has traditionally been measured and how it could potentially be better measured in the future. This study 
relies largely on traditional measures such as ridership and project costs, which do not give weight to considerations like quality of life or the number of averted automobile trips. Having some way to measure these more nebulous parts of performance, even if it is imperfect, is necessary if the benefits of urban rail transit are to be described and quantified. UTA's work to develop the Access to Opportunity metric is one example of this, but is ultimately only part of the larger social context.

Success also has a temporal component. If a corridor's performance is measured just once at an arbitrary moment, for example two years after it opens, many developments may not yet have had the chance to materialize. Zoning codes may have to be changed, a developer may have to acquire the land, and then build on it before enhanced ridership grows and a TOD zone comes to fruition. If performance is measured twenty years after opening, a much more accurate portrayal of how well the corridor has attracted new residents and businesses can be seen. However, justifying present day funds for results that may take a generation to materialize is difficult politically, especially when funds are tight and strong results are not guaranteed.

\subsection{Research Context}

Both the quantitative and qualitative findings of this study contribute to the already existing body of research. In a quantitative sense, this study breaks new ground in assigning performance scores to individual corridors relative to each other. As noted in existing literature, performance measurements are meaningful only if they are compared to reasonable baselines, such as targeted performance, past performance, or fair peer 
comparisons (TCRP Report 141, 2010). This study does all three by considering forecasted and actual ridership and costs, whether ridership has increased or decreased over time, and a performance evaluation process that compares nineteen urban rail transit corridors in three comparable cities. A robust performance metric can thus be constructed based on the results of this study.

While the performance score results may be challenged in the future by other researchers quantifying performance or examining corridor level trends, this study provides a research methodology that can be followed or expanded upon for systematic performance evaluations of fixed guideway systems in the future. In the current literature, there is not a comparable analog to the performance metric methodology developed in this study.

This study also found explanatory factors for the performance scores observed. Higher population density, lower median income, higher percentage of renter occupied units, higher job density, higher walkability, a lower number of park and rides spaces, lower headways between trains, and lower average train speeds each had a statistically significant relationship in predicting a higher performance score, or a higher ridership or financial subscore. Higher density and walkability measures predicting better performance make logical sense, as do reduced headways between trains. Findings of higher percentage renter occupied units and lower median income predicting performance may highlight the role that these corridors play in areas dominated by renters, particularly low income renters. This could be a future direction of research. Somewhat more 
surprising were the findings that having a lower number of park and ride spaces and a lower average train speed predicted higher performance. Many of the corridors that performed well were often dense, shorter corridors nearer to the urban core, where there is less room for park and rides and trains tend to operate at slower speeds. This is likely a prime example of where strong correlation does not equal causation, since intentionally operating trains slower is almost certainly not a predictor of success.

While these ten corridor characteristics have not been directly correlated with a performance metric before, they have been considered in previous research as drivers of urban rail transit ridership. Both academic and practitioner literature has found that higher densities have driven higher ridership (TCRP Report 88, 2003; Kuby et al. 2004; Taylor et al. 2009; TCRP Report 167, 2014). Service frequency and percentage of renter occupied units were also found to be predictive factors by Kuby et al. (2004), and have been reaffirmed here. Among the factors previously found to be responsible for increased ridership by Taylor et al. (2009) that were not found to increase performance in this study were median income, bus connections available, and park and ride spaces available. In fact, park and ride spaces available were found to have a negative predictive effect on performance in this study, in defiance of both Kuby et al. (2004) and Taylor et al. (2009). Strong regional economic growth has also been found to be highly correlated with rail transit system successes (Taylor and Haas, 2002), and it should thus be noted that Denver, Salt Lake City, and Portland have all experienced population and economic growth exceeding the national average in the time since their rail transit systems have been operating. 
Asking whether the investments made in rail transit systems in these three cities over the past few decades have delivered more in return than their upfront costs is a reasonable question. The answer, however, defies simple explanation. The true benefits these systems may have provided, from reducing road congestion to spurring business development to enhancing quality of life, would be a massive undertaking. A reasonable proxy may be found in the willingness of the general public to tax itself in order to fund these investments in each city, suggesting an understanding that urban rail transit serves as something of a public good.

Future research on this topic may make use of this study's methodological framework to evaluate corridor performance on a nationwide scale rather than in just the three cities investigated here. Beyond upscaling the methodology, work could also be done on making measurements of system performance and the effects of urban rail transit on cities more robust. For example, future research could quantify the economic benefits that urban rail transit systems provide to the cities they serve. Current literature often examines one dimension, such as job accessibility or increased property values, but to capture the true value of these systems relative to their costs, a more in depth and holistic investigation is necessary. These harder to measure and somewhat more subjective measures would likely have to be done one city at a time where comparable apples-toapples data for the multiple municipalities and corridors involved were available. Ultimately, focusing on data that are comparable across metro areas as in this study can have its limitations, since important measures like TOD are often measured differently in each city and are not accessible in data repositories like the NTD. 
A final, more qualitative suggestion for future research that would aid in understanding the nuances of urban rail transit systems is a more in depth look at the coalition building process when planning, constructing, and operating new corridors. A case study in Denver by Jonas, Goetz, and Bhattacharjee (2012) demonstrates the role that the support of the business community and Denver Metro Chamber of Commerce played in the success of the Fastracks vote and overcoming regional animosity to partnerships. Further attempts at understanding how support from businesses and community partners is important to getting a project off the ground, how developers respond to forthcoming and already opened rail transit lines, and how this confluence of interests drives political support and the funding process forward would yield significant insights into the ingredients needed to build successful rail transit corridors. 


\section{CHAPTER 7: CONCLUSION}

New urban rail transit systems have been built in more than a dozen American cities in the past few decades, primarily in traditionally car dependent Sunbelt cities. These expensive public projects have used primarily federal but also local funds to be realized. Unlike the original urban heavy rail projects of the 1960s and 1970s, namely BART in the Bay Area, the Washington Metro, and MARTA in Atlanta, most of these projects have used light rail technology, and perhaps more importantly have been built out using a piecemeal approach rather than as a complete system the way the three original projects were. This corridor by corridor approach has largely been overlooked in the research literature on the topic, which has tended to either compare entire systems to each other or zoom in all the way to the individual station level to conduct analyses.

This study has both built on previous research of urban rail transit performance and introduced evaluation of performance at the corridor level in an effort to bridge the gap that currently exists, using both quantitative and qualitative methods. The first part of the study was centered on constructing a performance metric for each of the nineteen defined rail transit corridors in Denver, Salt Lake City, and Portland. Since the question of what constitutes strong performance is inherently riddled with value judgments, a performance score was constructed for each corridor with data that were comparable between each of the cities in question. These measures included corridor ridership per 
mile, corridor ridership growth, corridor capital construction costs, and operating costs by corridor based on vehicle operating costs per mile and per hour. After the performance scores were constructed, the scores for each corridor were compared to ten different corridor characteristics using tests of regression. Thus, corridor performance was correlated with the potential predictive factors of population density, median income, percentage renter occupied units, percent in the labor force, job density, walkability, park and ride spaces, bus route connections, headways, and average train speed for each corridor.

Results showed that none of the three cities' rail transit corridors clearly outperformed other cities', although significant variability in performance of corridors within each city was observed for ridership, capital cost, operating cost, and ultimately performance score figures. This lends credibility to the notion that all corridors are not created equal, with some being extremely strong performers and others performing poorly. The factors found to have a statistically significant relationship with predicting higher performance were higher population density, lower median income, higher percentage of renter occupied units, higher job density, higher walkability, a lower number of park and rides spaces, lower headways between trains, and lower average train speeds. These generally stand in agreement with previous research, with lower median income, lower number of park and ride spaces, and lower average train speeds being exceptions. The highest performing corridors tended to be in central areas with less parking space and lower average train speeds. 
In addition to the quantitative analysis, interviews with officials from each transit agency and each local regional council of governments in each city were conducted to garner a more nuanced perspective of the data. None of the interviewees objected to the measures of performance used by the metric, but often did recommend adding criteria that would take into account measures such as enhanced accessibility and avoided automobile trips to make the metric stronger. Interviewees were generally not surprised by headways and population density being correlated with higher performance. They also described other elements they deemed to be important in ensuring corridors are successful, especially ensuring that the local business community and surrounding municipalities are on board with the development plans.

Analyzing performance at the level of the corridor provides a much more nuanced perspective of urban rail transit than do system-wide performance metrics, and unlike in depth case studies of certain stations, can serve as a metric of comparison as well.

Lessons from past corridor investments can guide future investments in a way that avoids making costly mistakes, and allows for better planning for factors that will enhance the success of a corridor. While any performance score is inherently quantitative in nature, investigating which qualitative factors are driving quantitative performance is no less important. It is only through such more holistic analyses that urban rail transit projects can be properly understood. 


\section{REFERENCES}

Al-Mosaind, M., Dueker,K. and J. Strathman. Light rail transit stations and property values: a hedonic price approach. Transportation Research Record: Journal of the Transportation Research Board, 1400 (1993), pp. 90-94.

Arrington, GB., and K.I. Sloop. 2009. New Transit Cooperative Research Program Research Confirms Transit-Oriented Developments Produce Fewer Auto Trips. Institute of Transportation Engineers. ITE Journal 79, 6: 26-29.

Babalik-Sutcliffe, E. 2002. Urban rail systems: analysis of the factors behind success. Transport Reviews 22 (4): 415-447.

Barnes, G. 2005. The Importance of Trip Destination in Determining Transit Share. Journal of Public Transportation 8, 2: 1-15.

Boarnet, M. 2017. Land Use, Travel Behavior, and Disaggregate Travel Data. In The Geography of Urban Transportation ed. G. Giuliano and S. Hanson, 164-184. New York: The Guilford Press.

Boyle, D. 2006. Easy to apply, short range, fixed-route, bus and rail transit ridership forecasting methods. Transit Cooperative Research Program (TCRP) Synthesis Report 66.

Brown, B. and C. Werner. 2008. Before and after a new light rail stop: Residents attitudes, travel behavior, and obesity. Journal of the American Planning Association 75 (1): 5-12. 
Calthorpe, P., 1993. The Next American Metropolis: Ecology, Community and the American Dream. Princeton, NJ: Princeton Architectural Press.

Carroll, M., C. Carlyle, and M. Seman. 2015. The economic and fiscal impacts of development near DART stations 2014-2015. University of North Texas, Economics Research Group.

City and County of Denver. 2017. Denver Moves: Transit Plan. Nelson Nygaard.

Cervero, R., 2003. Effects of Light and Commuter Rail Transit on Land Prices: Experience in San Diego County. Report University of California.

Cervero, R., 2006. Alternative approaches to modeling the travel-demand impacts of smart growth. J. Am. Planning Association 72, 285-295.

Cervero, R., Adkins, A., and C. Sullivan. 2010. Are Suburban TODs Over-Parked? Journal of Public Transportation 13 (2): 47-70.

Cervero, R., and M. Duncan. 2001. Transit's Value Added Effects: Light and Commuter Rail Services and Commercial Land Values. Transportation Research Record 1805 (02): 2273.

Cervero, R., and E. Guerra. 2011. To T or Not to T: A Ballpark Assessment of the Costs and Benefits of Urban Rail Transportation. Public Works Management \& Policy 16 (2): 111-128.

Cervero, R. and K. Kockelman. 1997. Travel Demand and the 3Ds: Density, Diversity, and Design. Transportation Research Part D 2 (3): 199-219. 
Cox, W. 2002. The Illusion of Transit Choice. Veritas, 34-42.

Dickey, J.W. 1983. Metropolitan Transportation Planning, 2nd edition. McGraw Hill, New York.

Docherty, I., J. Shaw, R. Knowles, and D. Mackinnon. 2009. Connecting for competitiveness: the future of transport in UK city regions. Public Money \& Management 29 (5): 321-328.

Dueker, K., and M. Bianco. 1999. Light-rail-transit impacts in Portland: the first ten years. Transportation Research Record 1685 (1): 171-180.

Duff, D., Gill E., Woodman, G., and T. Coburn. 2010. "Legal Handbook for the New Starts Process.” TCRP Legal Research Digest, No. 30 (February).

Eddington, R. 2006. Transport's Role in Sustaining the UK's Productivity and Competitiveness. The Stationery Office, London.

Evans, J. E. TCRP Report 95: Road Value Pricing: Traveler Response to Transportation System Changes, Chapter 9: Transit Scheduling and Frequency. Transportation Research Board of the National Academies, Washington, D.C., 2004.

Ewing, R., and R. Cervero. 2017. “Does Compact Development Make People Drive Less?” The Answer is Yes. Journal of the American Planning Association 83 (1): $19-25$.

Ewing, R., and S. Hamidi. 2014. Longitudinal Analysis of Transit's Land Use Multiplier in Portland (OR). Journal of the American Planning Association 80 (2): 123-137. 
Ewing, R., Tian, G., Lyons, T., and K. Terzano. 2017. Trip and parking generation at transit-oriented developments: Five US case studies. Landscape and Urban Planning 160: 69-78.

Fan, Y., A. Guthrie, and D. Levinson. 2012. Impact of light-rail implementation on labor market accessibility: a transportation equity perspective. The Journal of Transport and Land Use 5 (3): 28-39.

Federal Transit Administration. 2015. "Before-and-After Studies of New Starts Projects: Report to Congress. Green Line Light Rail Project; Portland, Oregon.” https://www.transit.dot.gov/funding/grant-programs/capital-investments/greenline-light-rail-project-portland-oregon

Federal Transit Administration. 2016. "Before-and-After Studies of New Starts Projects: Report to Congress. Mid-Jordan Light Rail Project; Salt Lake City, Utah.” https://www.transit.dot.gov/funding/grant-programs/capital-investments/midjordan-light-rail-project-salt-lake-city-utah

Federal Transit Administration. 2018a. Capital Investment Grant Fact Sheet (Section 5309). https://www.transit.dot.gov/funding/grant-programs/capital-

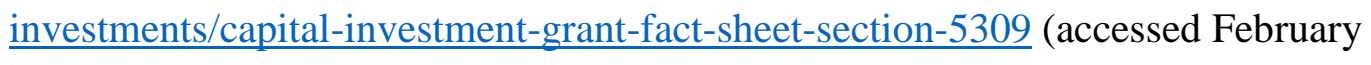
28, 2018).

Federal Transit Administration. 2018b. Capital Investment Grant Program Overview. https://www.transit.dot.gov/funding/grant-programs/capital-investments/capitalinvestment-grant-program-overview (accessed February 28, 2018). 
Flyvbjerg, B., Holm, M., and S. Buhl. 2002. Understanding costs in public works projects: error or lie? Journal of the American Planning Association 68: 279-295.

Gomez-Ibanez, J. 1996. Big-City Transit Ridership, Deficits, and Politics Avoiding Reality in Boston. Journal of the American Planning Association 62 (1): 30-50.

Giuliano, G. 2004. Land Use Impacts of Transportation Investments. In The Geography of Urban Transportation, ed. S. Hanson and G. Giuliano, 237-273. New York: The Guilford Press.

Hess, D., and T. Almeida. 2006. Impact of Proximity to Light Rail Rapid Transit on Station-area Property Values in Buffalo, New York. Urban Studies 44 (5/6): 1041-1068.

Holvad, T., and S. Leleur. 2015. Transport projects and wider economic impacts. In Handbook on Transport and Development, ed. R. Hickman, M. Givoni, D. Bonilla, and D. Banister, 259-272. Cheltenham, UK: Edward Elgar Publishing Limited.

Johnston, R. 2004. The urban transportation planning process. In The Geography of Urban Transportation, ed. S. Hanson, $3^{\text {rd }}$ edn, 115-140. New York: The Guilford Press.

Jonas, A., Goetz, A., and S. Bhattacharjee. 2012. City-regionalism as a Politics of Collective Provision: Regional Transport Infrastructure in Denver, USA. Urban Studies 51: 2444-2465. 
Knapp, G., Ding, C., and L. Hopkins. 2001. Do Plans Matter? The Effect of Light Rail Plans on Land Values in Station Areas. Journal of Planning Education and Research 21: 32-39.

Knowles, R., 2012. Transit oriented development in Copenhagen, Denmark: from the Finger Plan to Ørestad. Journal of Transport Geography 22: 251-261.

Knowles, R., and F. Ferbrache. 2016. Evaluation of wider economic impacts of light rail investment on cities. Journal of Transport Geography 54: 430-439.

Kuby, M., Barranda, A., and C. Upchurch. 2004. Factors influencing light-rail station boardings in the United States. Transportation Research Part A 38: 223-247.

Landis, J., Gutathakurta, S., Huang, W., and M. Zhang. 1995. Rail Transit Investments, Real Estate Values, and Land Use Change: A Comparative Analysis of Five California Rail Transit Systems. University of California at Berkeley, Institute of Urban and Regional Development.

Lewis-Workman, S., White, B., McVey, S., and F. Spielberg. 2008. The predicted and actual impacts of new starts projects-capital costs and ridership. Technical report, Federal Transit Administration and Vanasse Hangen Brustlin, Inc.

Litman, T. 2006. Evaluating public transit benefits and costs. Victoria Transport Policy Institute.

Litman, T. 2009. Evaluating rail transit criticism. Victoria, BC: Victoria Transport Policy Institute. 
Mayworm, P. Lago, A., and J. McEnroe. 1980. Patronage impacts of changes in transit fares and services. Urban Mass Transportation Agency, Washington, DC.

Mackett, R. 1998. Why are travel demand forecasts so often wrong (and does it matter)? Paper written for presentation at the UTSG Annual Conference, Dublin, January 1998.

Meyer, M. and E. Miller. "Demand Analysis.” In Urban Transportation Planning, $2^{\text {nd }}$ edn, 247-331. New York: McGraw Hill.

Miller, H. 2017. Theories and Models in Transportation Planning. In The Geography of Urban Transportation ed. G. Giuliano and S. Hanson, 164-184. New York: The Guilford Press.

Nasri, A., and L. Zhang. 2014. The analysis of transit-oriented development (TOD) in Washington, D.C. and Baltimore metropolitan areas. Transport Policy 32: 172179.

Niedzielski, M. and E. Malecki. 2012. Making tracks: Rail networks in world cities. Annals of the Association of American Geographers 102 (6): 1409-1431.

Njus, E. 2017. TriMet weighing \$1.7 billion bond measure for light rail, street projects. The Oregonian 28 September 2017.

O’Toole, R. 2010. Defining Success: The Case against Rail Transit. Policy Analysis, no. 663. 
Pickrell, D. 1992. A Desire Named Streetcar Fantasy and Fact in Rail Transit Planning. Journal of the American Planning Association 58, 158-176.

Pratt, R.H., Pederson, N.J., Mather, J.J. 1977. Traveler Response to Transportation System Changes: A Handbook for Transportation Planners. Federal Highway Administration, Washington, DC.

Pucher, J. 2004. Public Transportation. In The Geography of Urban Transportation, ed. S. Hanson and G. Giuliano, 199-236. New York: The Guilford Press.

Pushkarev, B.J., Zupan, M., Cumella, R.S. 1982. Urban Rail in America: An Exploration of Criteria for Fixed Guideway Transit. Indiana University Press, Bloomington.

Ratner, K. 2001. The Relationship of United States Rail Transit Development and Success with Urban Population, Employment and Congestion Characteristics PhD. diss., University of Denver.

Ratner, K., and A. Goetz. 2013. The reshaping of land use and urban form in Denver through transit-oriented development. Cities 30: 31-46.

Regional Transportation District. 2018a. Facts \& Figures: RTD by the numbers. http://www.rtd-denver.com/factsAndFigures.shtml (accessed February 28, 2018).

Regional Transportation District. 2018b. History of the West Rail Line. http://www.rtdfastracks.com/media/uploads/wc/W-Line-HistoryFactSheetInserts.pdf (accessed February 28, 2018). 
Richmond, J. 1998. New rail transit investments - a review: summary paper. Taubman Centre, Kennedy School of Government, Harvard University and MIT Cooperative Mobility Research Program.

Spielberg, F., Lewis-Workman, S., Buffkin, T., Clements, S., and J. Swartz. 2003. "The Predicted and Actual Impacts of New Starts Projects.” Washington DC: US Department of Transportation Federal Transit Administration.

Taylor, B. and P. Haas. 2002. Increasing Transit Ridership: Lessons from the Most Successful Transit Systems in the 1990s. Mineta Transportation Institute Report 01-22.

Taylor, B., Miller, D., Iseki, H., and C. Fink. Nature and/or Nurture? Analyzing the Determinants of Transit Ridership across US Urbanized Areas. Transportation Research Part A: Policy and Practice, Vol. 43, No. 1, 2009, pp. 60-77.

Transit Cooperative Research Program Report 27. Building Transit Ridership. Washington, D.C.: National Academy Press, 1997.

Transit Cooperative Research Program Report 88. A Guidebookfor Developing a Transit Performance-Measurement System. Washington, D.C.: National Academy Press, 2003.

Transit Cooperative Research Program Report 111. Elements Needed to Create HighRidership Transit Systems. National Academy Press, 2007. 
Transit Cooperative Research Program Report 141. A Methodology for Performance Measurement and Peer Comparison in the Public Transportation Industry. National Academy Press, 2010.

Transit Cooperative Research Program Report 167. Making Effective Fixed-Guideway Transit Investments: Indicators of Success. National Academy Press, 2014.

TriMet. 2018a. The TriMet Story. https://trimet.org/history/trimetstory.htm (accessed February 28, 2018).

TriMet. 2018b. MAX Light Rail Project History. https://trimet.org/history/maxoverview.htm (accessed February 28, 2018).

United Press International. 1988. \$5 Million ok'd for light rail. Deseret News 10 October 1988.

Upchurch, C., and M. Kuby. 2013. Evaluating light rail sketch planning: actual versus predicted station boardings in Phoenix. Transportation 41: 173-192.

Urban Mass Transportation Administration. 1976. "Federal Policy on Assistance for Major Urban Mass Transportation Investments.” Federal Register 41 (185): 41512-14.

Utah Transit Authority. 2018a. UTA History. https://www.rideuta.com/uploads/History_factsheet_january2015.pdf (Accessed February 28, 2018). 
Utah Transit Authority. 2018b. Utah Transit Authority Fast Facts.

https://www.rideuta.com/-/media/Files/About-UTA/Annual-Reports/102300-

01_UTA_2016_Fast_Facts_FNL_04a_Dec2016.ashx?la=en (accessed February $28,2018)$.

Voulgaris, C. 2017. Crystal Balls and Black Boxes: Optimism Bias in Ridership and Cost Forecasts for New Starts Rapid Transit Projects. PhD. diss., University of Denver. University of California, Los Angeles.

Warburton, N. 2007. UTA on track for U.S. funds. Deseret News 25 September 2007.

Warburton, N., and L. Dethman. 2006. Tax to build 3 rail lines, fix highway. Deseret News 22 December 2006.

Weinstein, B.L., Clower, T.L., 1999. The Initial Economic Impacts of the DART LRT System. Report University of North Texas Centre for Economic Development and Research. Dallas Area Rapid Transit. 
APPENDIX A: RIDERSHIP FIGURES 


\begin{tabular}{|c|c|c|c|c|c|c|c|}
\hline $\begin{array}{c}\text { Corridor } \\
\text { City }\end{array}$ & $\begin{array}{c}\text { Corridor } \\
\text { Name }\end{array}$ & Stations & $\begin{array}{c}2017 \\
\text { Weekday } \\
\text { Average }\end{array}$ & $\begin{array}{c}2016 \\
\text { Weekday } \\
\text { Average }\end{array}$ & $\begin{array}{c}2015 \\
\text { Weekday } \\
\text { Average }\end{array}$ & $\begin{array}{c}2014 \\
\text { Weekday } \\
\text { Average }\end{array}$ & $\begin{array}{c}2013 \\
\text { Weekday } \\
\text { Average }\end{array}$ \\
\hline \multirow{11}{*}{ Denver } & \multirow{11}{*}{ Central } & 18th Street Stations & 5237 & 6096 & 8306 & 6241 & 5074 \\
\hline & & 16th Street Stations & 9566 & 9944 & 9475 & 11641 & 11845 \\
\hline & & Theater District & 4409 & 4869 & 4734 & 5483 & 4371 \\
\hline & & Colfax at Auraria & 11324 & 11414 & 12273 & 12251 & 12828 \\
\hline & & Union Station & 9544 & 7706 & 6448 & 5841 & 4727 \\
\hline & & Pepsi Center & 1131 & 1065 & 964 & 958 & 744 \\
\hline & & Sports Authority Field & 471 & 590 & 535 & 450 & 466 \\
\hline & & Auraria West & 4130 & 3882 & 3729 & 4082 & 3019 \\
\hline & & 10th \& Osage & 4026 & 4174 & 3949 & 4081 & 3470 \\
\hline & & Alameda & 5166 & 4763 & 4392 & 4533 & 5060 \\
\hline & & Broadway & 11847 & 12359 & 13504 & 14592 & 12922 \\
\hline \multirow{5}{*}{ Denver } & \multirow{5}{*}{$\begin{array}{l}\text { South- } \\
\text { west }\end{array}$} & Evans & 1792 & 1723 & 1865 & 1807 & 1729 \\
\hline & & Englewood & 5160 & 5037 & 5497 & 5606 & 5274 \\
\hline & & Oxford/Sheridan & 1172 & 1129 & 1196 & 1200 & 1018 \\
\hline & & Littleton & 3370 & 3392 & 3781 & 3835 & 3560 \\
\hline & & Mineral & 5213 & 4901 & 4738 & 4740 & 4374 \\
\hline \multirow{13}{*}{ Denver } & \multirow{13}{*}{$\begin{array}{l}\text { South- } \\
\text { east }\end{array}$} & Louisiana/Pearl & 1724 & 1642 & 1310 & 1397 & 1295 \\
\hline & & University of Denver & 4119 & 3827 & 3749 & 3853 & 3624 \\
\hline & & Colorado & 4550 & 5075 & 5226 & 5773 & 5376 \\
\hline & & Yale & 1461 & 1599 & 1621 & 1739 & 1589 \\
\hline & & Southmoor & 4921 & 6075 & 6227 & 6553 & 5976 \\
\hline & & Dayton & 1378 & 1150 & 1178 & 1173 & 1096 \\
\hline & & Nine Mile & 6591 & 6611 & 6599 & 6689 & 6154 \\
\hline & & Belleview & 2486 & 1974 & 1827 & 1898 & 5035 \\
\hline & & Orchard & 1457 & 1396 & 1352 & 1471 & 1314 \\
\hline & & Arapahoe & 2969 & 3245 & 3155 & 3409 & 3164 \\
\hline & & Dry Creek & 1986 & 1958 & 1969 & 2132 & 1971 \\
\hline & & County Line & 1691 & 1701 & 1722 & 2010 & 1907 \\
\hline & & Lincoln & 6244 & 5244 & 4451 & 4617 & 4425 \\
\hline \multirow{6}{*}{ Denver } & \multirow{6}{*}{$\begin{array}{l}\text { Five } \\
\text { Points }\end{array}$} & 16th Street Stations & 2374 & 2467 & 2351 & 2888 & 2939 \\
\hline & & 18th Street Stations & 1299 & 1513 & 2061 & 1548 & 1259 \\
\hline & & 20th \& Welton & 831 & 920 & 1060 & 947 & 815 \\
\hline & & 25th \& Welton & 783 & 796 & 1046 & 1262 & 1117 \\
\hline & & 27th \& Welton & 664 & 712 & 843 & 806 & 807 \\
\hline & & 30th \& Downing & 2580 & 2517 & 2578 & 2501 & 3417 \\
\hline \multirow{15}{*}{ Denver } & \multirow{15}{*}{ West } & Union Station & 6940 & 5603 & 4690 & 4249 & 3438 \\
\hline & & Pepsi Center & 823 & 775 & 701 & 697 & 541 \\
\hline & & Sports Authority Field & 343 & 430 & 389 & 327 & 339 \\
\hline & & Auraria West & 3004 & 2824 & 2712 & 2969 & 2196 \\
\hline & & Decatur/Federal & 2156 & 2139 & 2047 & 2079 & 2222 \\
\hline & & Knox & 785 & 736 & 663 & 625 & 764 \\
\hline & & Perry & 686 & 570 & 530 & 616 & 658 \\
\hline & & Sheridan & 1693 & 1558 & 1520 & 1559 & 1581 \\
\hline & & Lamar & 781 & 693 & 674 & 724 & 795 \\
\hline & & Wadsworth & 2916 & 2765 & 2629 & 2902 & 2948 \\
\hline & & Garrison & 761 & 679 & 667 & 737 & 850 \\
\hline & & Oak & 1651 & 1469 & 1351 & 1358 & 1480 \\
\hline & & Federal Center & 2462 & 2471 & 2468 & 2699 & 2973 \\
\hline & & Red Rocks College & 393 & 328 & 358 & 358 & 419 \\
\hline & & Golden & 2351 & 2133 & 1724 & 1801 & 2205 \\
\hline
\end{tabular}




\begin{tabular}{|c|c|c|c|c|c|c|c|}
\hline $\begin{array}{c}\text { Corridor } \\
\text { City }\end{array}$ & \begin{tabular}{|c} 
Corridor \\
Name
\end{tabular} & Stations & \begin{tabular}{|c|}
2017 \\
Weekday \\
Average \\
\end{tabular} & \begin{tabular}{|c|}
2016 \\
Weekday \\
Average \\
\end{tabular} & \begin{tabular}{|c|}
2015 \\
Weekday \\
Average \\
\end{tabular} & \begin{tabular}{|c|}
2014 \\
Weekday \\
Average \\
\end{tabular} & $\begin{array}{c}2013 \\
\text { Weekday } \\
\text { Average } \\
\end{array}$ \\
\hline \multirow{8}{*}{ Denver } & \multirow{8}{*}{ Airport } & Union Station & 11252 & 9086 & N/A & N/A & N/A \\
\hline & & 38th \& Blake & 1283 & 1056 & N/A & N/A & N/A \\
\hline & & Colorado & 1782 & 1533 & N/A & N/A & N/A \\
\hline & & Central Park & 4116 & 3988 & N/A & N/A & N/A \\
\hline & & Peoria & 4998 & 2313 & N/A & N/A & N/A \\
\hline & & 40th \& Airport & 3840 & 3687 & N/A & N/A & N/A \\
\hline & & 61st \& Pena & 805 & 570 & N/A & N/A & N/A \\
\hline & & Denver Int'l Airport & 10256 & 11107 & N/A & N/A & N/A \\
\hline \multirow{16}{*}{$\begin{array}{l}\text { Salt } \\
\text { Lake } \\
\text { City }\end{array}$} & \multirow{16}{*}{ Central } & Salt Lake Central & 2532 & 2964 & 2834 & 2788 & 2986 \\
\hline & & Old Greektown & 2244 & 2320 & 1728 & 1676 & 1444 \\
\hline & & Planetarium & 1786 & 2234 & 2298 & 2416 & 2276 \\
\hline & & Arena & 3924 & 4535 & 4695 & 4692 & 4568 \\
\hline & & Temple Square & 1739 & 2096 & 2194 & 2182 & 2219 \\
\hline & & City Center & 6226 & 6383 & 6588 & 6507 & 6662 \\
\hline & & Gallivan Plaza & 3542 & 3787 & 4046 & 3924 & 3823 \\
\hline & & Courthouse & 11660 & 11886 & 12828 & 13290 & 13628 \\
\hline & & 900 South & 2428 & 2318 & 2382 & 2390 & 2250 \\
\hline & & Ballpark & 4296 & 4298 & 4160 & 4390 & 4582 \\
\hline & & Central Pointe & 8246 & 8210 & 8560 & 8594 & 7202 \\
\hline & & Millcreek & 3290 & 3158 & 3370 & 3538 & 3544 \\
\hline & & Meadowbrook & 2930 & 3086 & 3350 & 3566 & 3510 \\
\hline & & Murray North & 1878 & 1860 & 1888 & 2782 & 3282 \\
\hline & & Murray Central & 6110 & 6354 & 6780 & 6176 & 5252 \\
\hline & & Fashion Place West & 3822 & 4018 & 4380 & 4526 & 4422 \\
\hline \multirow{8}{*}{$\begin{array}{l}\text { Salt } \\
\text { Lake } \\
\text { City }\end{array}$} & \multirow{8}{*}{$\begin{array}{l}\text { Sandy/ } \\
\text { Draper }\end{array}$} & Midvale Fort Union & 1614 & 1714 & 1798 & 1868 & 1910 \\
\hline & & Midvale Center & 1346 & 1482 & 1612 & 1672 & 1786 \\
\hline & & Historic Sandy & 1532 & 1650 & 1712 & 1740 & 1770 \\
\hline & & Sandy Expo & 652 & 694 & 650 & 624 & 666 \\
\hline & & Sandy Civic Center & 1088 & 1140 & 1384 & 1444 & 2772 \\
\hline & & Crescent View & 932 & 986 & 1026 & 1006 & 944 \\
\hline & & Kimballs Lane & 520 & 552 & 620 & 756 & 734 \\
\hline & & Draper Town Center & 1490 & 1614 & 1516 & 1466 & 1574 \\
\hline \multirow{9}{*}{$\begin{array}{l}\text { Salt } \\
\text { Lake } \\
\text { City }\end{array}$} & \multirow{9}{*}{$\begin{array}{l}\text { South } \\
\text { Jordan }\end{array}$} & Bingham Junction & 986 & 816 & 794 & 740 & 608 \\
\hline & & Historic Gardner & 280 & 290 & 294 & 320 & 306 \\
\hline & & West Jordan City Center & 1084 & 1060 & 1118 & 1176 & 1022 \\
\hline & & 2700 Sugar Factory Road & 676 & 682 & 694 & 742 & 760 \\
\hline & & Jordan Valley & 874 & 886 & 956 & 942 & 776 \\
\hline & & 4800 Old Bingham Hwy & 1120 & 1110 & 1172 & 1202 & 1196 \\
\hline & & 5600 Old Bingham Hwy & 308 & 284 & 304 & 264 & 242 \\
\hline & & South Jordan Pkwy & 308 & 248 & 242 & 252 & 212 \\
\hline & & Daybreak Pkwy & 2302 & 2254 & 2340 & 2368 & 2250 \\
\hline \multirow{4}{*}{$\begin{array}{l}\text { Salt } \\
\text { Lake } \\
\text { City }\end{array}$} & \multirow{4}{*}{$\begin{array}{l}\text { West } \\
\text { Valley } \\
\text { City }\end{array}$} & River Trail & 552 & 586 & 546 & 544 & 552 \\
\hline & & Redwood Junction & 1028 & 1138 & 1154 & 1140 & 854 \\
\hline & & Decker Lake & 712 & 658 & 650 & 702 & 680 \\
\hline & & West Valley Central & 2650 & 2918 & 3120 & 3198 & 3320 \\
\hline \multirow{7}{*}{$\begin{array}{l}\text { Salt } \\
\text { Lake } \\
\text { City }\end{array}$} & \multirow{7}{*}{$\begin{array}{l}\text { Univer- } \\
\text { sity }\end{array}$} & Library & 2960 & 2900 & 3058 & 3222 & 3238 \\
\hline & & Trolley & 2930 & 3106 & 3242 & 3406 & 3130 \\
\hline & & 900 East & 1964 & 2102 & 2378 & 2422 & 2414 \\
\hline & & Stadium & 3752 & 4394 & 4760 & 5076 & 5030 \\
\hline & & U South Campus & 1718 & 2092 & 2356 & 2422 & 2200 \\
\hline & & \begin{tabular}{|l} 
Fort Douglas \\
\end{tabular} & 1116 & 1142 & 1222 & 860 & 916 \\
\hline & & U Medical Center & 3140 & 3168 & 3122 & 3136 & 2952 \\
\hline
\end{tabular}




\begin{tabular}{|c|c|c|c|c|c|c|c|}
\hline $\begin{array}{c}\text { Corridor } \\
\text { City }\end{array}$ & $\begin{array}{c}\text { Corridor } \\
\text { Name }\end{array}$ & Stations & $\begin{array}{c}2017 \\
\text { Weekday } \\
\text { Average }\end{array}$ & \begin{tabular}{|c|}
2016 \\
Weekday \\
Average \\
\end{tabular} & $\begin{array}{c}2015 \\
\text { Weekday } \\
\text { Average }\end{array}$ & $\begin{array}{c}2014 \\
\text { Weekday } \\
\text { Average }\end{array}$ & \begin{tabular}{|c|}
2013 \\
Weekday \\
Average \\
\end{tabular} \\
\hline \multirow{10}{*}{$\begin{array}{l}\text { Salt } \\
\text { Lake } \\
\text { City }\end{array}$} & \multirow{10}{*}{ Airport } & Gallivan Plaza & 715.952 & 827.357 & 856.674 & 856.056 & 833.529 \\
\hline & & City Center & 317.241 & 382.355 & 400.254 & 398.094 & 404.883 \\
\hline & & Temple Square & 1135.96 & 1164.66 & 1202 & 1187.18 & 1215.58 \\
\hline & & Arena & 646.208 & 690.955 & 738.171 & \begin{tabular}{|l|}
715.952 \\
\end{tabular} & 697.436 \\
\hline & & North Temple Bridge & 2590 & 2560 & 2618 & 2748 & 2362 \\
\hline & & Jackson/Euclid & 1520 & 1436 & 1372 & 1356 & 1022 \\
\hline & & Fairpark & 286 & 286 & 278 & 312 & 272 \\
\hline & & Power & 1064 & 994 & 1008 & 984 & 700 \\
\hline & & 1940 North Temple & 1478 & 1484 & 1562 & 1558 & 1378 \\
\hline & & Salt Lake Int'l Airport & 2390 & 2200 & 2218 & 2112 & 1960 \\
\hline \multirow{13}{*}{ Portland } & \multirow{13}{*}{ Central } & Mall/SW 5th \& 4th & 3195 & 3375 & 3525 & 3452 & 3351 \\
\hline & & SW 3rd \& Yamhill District & 1257 & 2543 & 2632 & 2660 & 2496 \\
\hline & & Oak/SW 1st & 1300 & 1258 & 1262 & 1178 & 1205 \\
\hline & & Skidmore Fountain & 1203 & 1225 & 1338 & 1308 & 1203 \\
\hline & & Old Town Chinatown & 1568 & 1495 & 1304 & 1308 & 1291 \\
\hline & & Rose Quarter TC & 3559 & 3659 & 3884 & 4077 & 4091 \\
\hline & & Convention Center & 2263 & 2167 & 2352 & 2685 & 2116 \\
\hline & & NE 7th Ave & 2037 & 1912 & 1653 & 1871 & 1871 \\
\hline & & Lloyd Center & 3783 & 4094 & 4380 & 5016 & 4467 \\
\hline & & Hollywood/NE 42nd & 4700 & 4734 & 4831 & 5062 & 5080 \\
\hline & & NE 60th Ave & 3041 & 3056 & 3174 & 3287 & 3256 \\
\hline & & NE 82nd Ave & 4762 & 5083 & 5273 & 5510 & 5418 \\
\hline & & Gateway/NE 99th & 14214 & 14620 & 15236 & 15918 & 15495 \\
\hline \multirow{12}{*}{ Portland } & \multirow{12}{*}{ Gresham } & E 102nd Ave & 2491 & 2615 & 2450 & 2596 & 2644 \\
\hline & & E 122nd Ave & 3894 & 3758 & 3622 & 3706 & 3743 \\
\hline & & E 148th Ave & 1700 & 1655 & 1585 & 1727 & 1705 \\
\hline & & E 162nd Ave & 3148 & 3106 & 3103 & 3409 & 3497 \\
\hline & & E 172nd Ave & 1117 & 1115 & 1144 & 1266 & 1214 \\
\hline & & E 181st Ave & 2083 & 2070 & 2109 & 2284 & 2304 \\
\hline & & Rockwood/W 188th & 1841 & 1883 & 2111 & 2264 & 2317 \\
\hline & & Ruby Junction/E 197th & 1189 & 1187 & 1182 & 1229 & 1180 \\
\hline & & Gresham Civic Neighborhood & 909 & 769 & 779 & 840 & 811 \\
\hline & & Gresham City Hall & 1147 & 1417 & 1479 & 1624 & 1722 \\
\hline & & Gresham Central & 2112 & 2092 & 2205 & 2421 & 2536 \\
\hline & & Cleveland Ave & 2182 & 2175 & 2320 & 2488 & 2580 \\
\hline \multirow{22}{*}{ Portland } & \multirow{22}{*}{$\begin{array}{l}\text { Hills- } \\
\text { boro }\end{array}$} & Pioneer Square N \& S & 4705 & 5438 & 5662 & 5714 & 5834 \\
\hline & & Galleria \& Library & 3243 & 3289 & 3310 & 3298 & 3084 \\
\hline & & Providence Park & 2467 & 2486 & 2369 & 2392 & 2342 \\
\hline & & Kings Hill/SW Salmon & 683 & 708 & 706 & 707 & 713 \\
\hline & & Goose Hollow/SW Jefferson & 1333 & 1281 & 1265 & 1307 & 1256 \\
\hline & & Washington Park & 1952 & 1770 & 1582 & 1650 & 1493 \\
\hline & & Sunset & 6239 & 6383 & 6128 & 6049 & 6034 \\
\hline & & Beaverton TC & 9378 & 9035 & 9530 & 9774 & 9704 \\
\hline & & Beaverton Central & 1680 & 1608 & 1619 & 1699 & 1646 \\
\hline & & Millikan Way & 3143 & 3344 & 3439 & 3448 & 3435 \\
\hline & & Beaverton Creek & 1797 & 1745 & 1593 & 1566 & 1596 \\
\hline & & Merlo Rd/SW 150th & 1689 & 1754 & 1977 & 1996 & 1935 \\
\hline & & Elmonica/SW 170th & 2877 & 2955 & 2943 & 2783 & 2637 \\
\hline & & Willow Creek/SW 188th & 3697 & 3880 & 3995 & 4175 & 4238 \\
\hline & & Quatama/NW 201st & 2850 & 2893 & 2844 & 2774 & 2648 \\
\hline & & Orenco/NW 231st & 2554 & 2360 & 2066 & 2002 & 2055 \\
\hline & & Hawthorn Farm & 814 & 797 & 811 & 932 & 995 \\
\hline & & Fair Complex/Hillsboro Apt & 1891 & 1867 & 1927 & 1899 & 1838 \\
\hline & & Washington/SE 12th & 1028 & 1047 & 1105 & 1228 & 1249 \\
\hline & & Tuality Hospital/SE 8th & 858 & 929 & 1054 & 1265 & 1252 \\
\hline & & Hillsboro Central/SE 3rd & 1570 & 1594 & 1599 & 1646 & 1641 \\
\hline & & Hatfield Government Center & 2262 & 2339 & 2763 & 2791 & 3142 \\
\hline
\end{tabular}




\begin{tabular}{|c|c|c|c|c|c|c|c|}
\hline $\begin{array}{c}\text { Corridor } \\
\text { City }\end{array}$ & $\begin{array}{c}\text { Corridor } \\
\text { Name }\end{array}$ & Stations & $\begin{array}{c}2017 \\
\text { Weekday } \\
\text { Average }\end{array}$ & $\begin{array}{c}2016 \\
\text { Weekday } \\
\text { Average }\end{array}$ & $\begin{array}{c}2015 \\
\text { Weekday } \\
\text { Average }\end{array}$ & \begin{tabular}{|c|}
2014 \\
Weekday \\
Average
\end{tabular} & $\begin{array}{c}2013 \\
\text { Weekday } \\
\text { Average }\end{array}$ \\
\hline \multirow{8}{*}{ Portland } & \multirow{8}{*}{$\begin{array}{l}\text { Clack- } \\
\text { amas }\end{array}$} & SE Main St & 1616 & 1733 & 1715 & 1599 & 1491 \\
\hline & & SE Division St & 1350 & 1464 & 1483 & 1491 & 1390 \\
\hline & & SE Powell Blvd & 1257 & 1333 & 1205 & 1039 & 971 \\
\hline & & SE Holgate St & 1184 & 1211 & 1234 & 1224 & 1209 \\
\hline & & Lents/SE Foster Rd & 1353 & 1375 & 1374 & 1377 & 1298 \\
\hline & & SE Flavel St & 1053 & 1181 & 1172 & 1140 & 1064 \\
\hline & & SE Fuller Rd & 779 & 828 & 858 & 846 & 814 \\
\hline & & Clackamas Town Center & 4507 & 4509 & 4707 & 4556 & 4639 \\
\hline \multirow{14}{*}{ Portland } & \multirow{14}{*}{$\begin{array}{l}\text { Milwau- } \\
\text { kie }\end{array}$} & Pioneer Courthouse \& Place & 2095 & 2217 & 2264 & N/A & N/A \\
\hline & & SW Madison \& Jefferson & 1990 & 1951 & 1661 & N/A & N/A \\
\hline & & SW Montgomery \& Mill & 2272 & 2462 & 2463 & $\mathrm{~N} / \mathrm{A}$ & $\mathrm{N} / \mathrm{A}$ \\
\hline & & SW College \& Jackson & 1279 & 1303 & 1316 & N/A & N/A \\
\hline & & Lincoln/SW 3rd & 545 & 508 & 416 & N/A & N/A \\
\hline & & South Waterfront & 969 & 895 & 777 & N/A & N/A \\
\hline & & OMSI & 690 & 642 & 602 & N/A & N/A \\
\hline & & SE Clinton St & 870 & 826 & 805 & N/A & N/A \\
\hline & & SE Rhine St & 619 & 597 & 481 & N/A & N/A \\
\hline & & Brooklyn/SE Holgate & 886 & 817 & 792 & N/A & N/A \\
\hline & & SE Bybee Ave & 867 & 866 & 856 & N/A & N/A \\
\hline & & SE Tacoma St & 1544 & 1577 & 1460 & N/A & N/A \\
\hline & & Southgate/Milwaukie & 1418 & 1404 & 1405 & N/A & N/A \\
\hline & & SE Park Ave & 3548 & 3505 & 4108 & N/A & N/A \\
\hline \multirow{14}{*}{ Portland } & \multirow{14}{*}{ Interstate } & Pioneer Courthouse \& Place & 2731 & 2889 & 4079 & 4327 & 4270 \\
\hline & & \begin{tabular}{|l} 
SW Pine \& SW Oak \\
\end{tabular} & 2626 & 2546 & 2239 & 1937 & 1902 \\
\hline & & NW Davis \& NW Couch & 835 & 1637 & 1342 & 1216 & 1221 \\
\hline & & NW Hoyt \& NW Glisan & 1691 & 1696 & 1683 & 1533 & 1503 \\
\hline & & Interstate Rose Quarter & 1468 & 1526 & 1528 & 1590 & 1586 \\
\hline & & Albina/N Mississippi & 702 & 667 & 646 & 679 & 647 \\
\hline & & Overlook Park & 1022 & 994 & 1009 & 928 & 910 \\
\hline & & N Prescott St & 1178 & 1167 & 1192 & 1199 & 1031 \\
\hline & & \begin{tabular}{|l|} 
N Killingsworth St \\
\end{tabular} & 1948 & 1971 & 1998 & 2089 & 2148 \\
\hline & & Rosa Parks & 1318 & 1322 & 1314 & 1300 & 1200 \\
\hline & & \begin{tabular}{|l|} 
N Lombard \\
\end{tabular} & 2786 & 2922 & 2936 & 3182 & 3061 \\
\hline & & Kenton/N Denver Ave & 1266 & 1221 & 1152 & 1144 & 1074 \\
\hline & & Delta Park/Vanport & 2277 & 2339 & 2457 & 2490 & 2263 \\
\hline & & Expo Center & 1096 & 867 & 943 & 902 & 797 \\
\hline \multirow{4}{*}{ Portland } & \multirow{4}{*}{ Airport } & Parkrose/Summer & 2244 & 2241 & 2308 & 2421 & 2343 \\
\hline & & Cascades & 1047 & 1092 & 1124 & 1088 & 1039 \\
\hline & & Mt Hood Ave & 651 & 642 & 629 & 584 & 549 \\
\hline & & Airport & 4694 & 3858 & 4076 & 3769 & 3532 \\
\hline
\end{tabular}




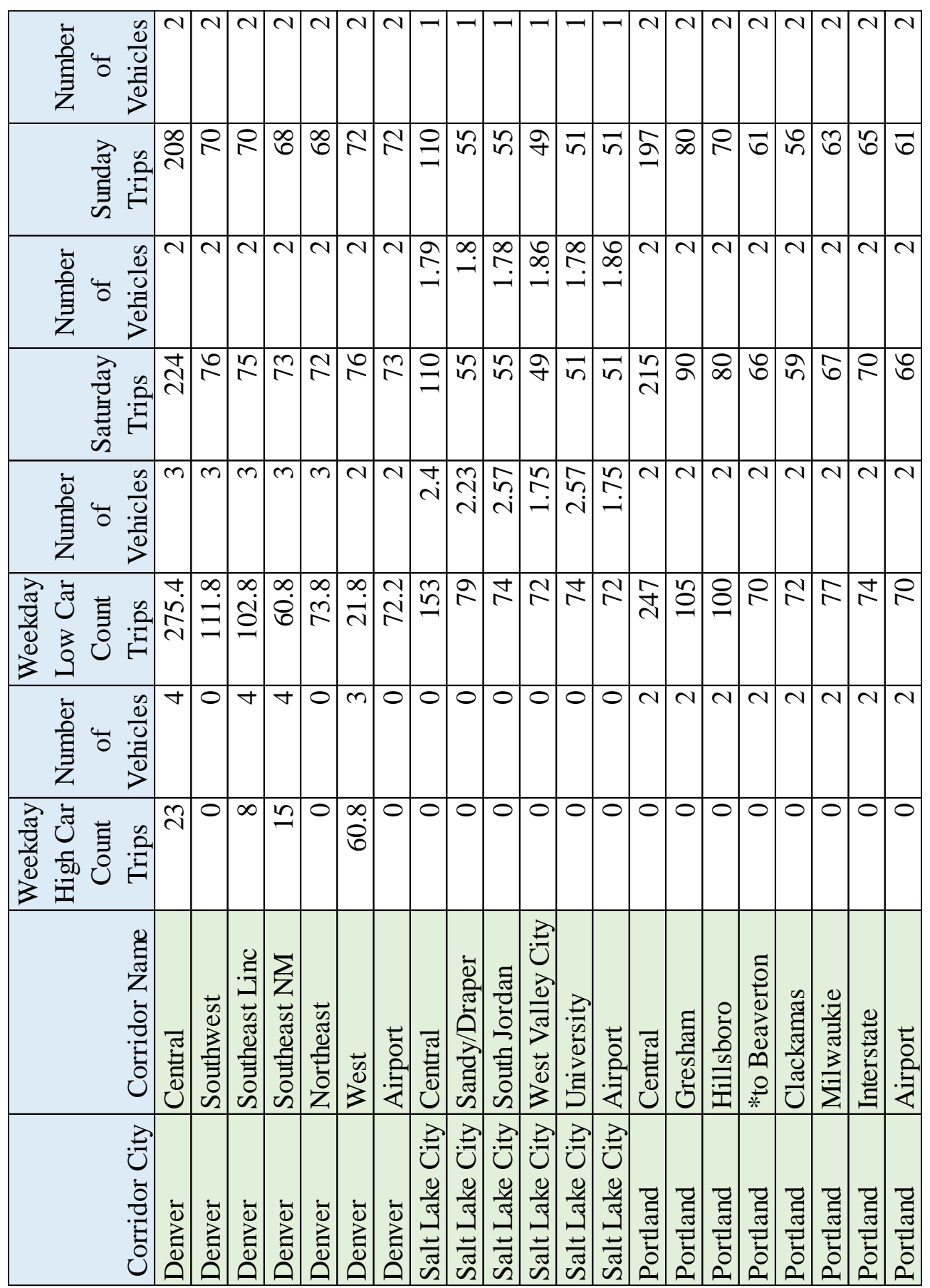




\section{APPENDIX C: BLOCK GROUPS WITHIN NETWORK DISTANCE BUFFERS}

The FIPS code of each block group included for the analysis of each corridor for is listed below.

Denver Central: 80310016002, 80310011023, 80310017011, 80310017013, 80310017015, 80310017012, 80310006001, 80310019021, 80310026012, 80310026011, 80310024032, 80310017021, 80310017014, 80310017022, 80310020001, 80310019011, 80310019012, 80310018001, 80310018002, 80310021003, 80310021002, 80310028023, 80310029011, 80310029012, 80310029013, 80310014031, 80310030011.

Denver Southwest: 80310014031, 80310030015, 80310014032, 80310030023, 80050057003, 80050057002, 80050060001, 80050060003, 80050062004, 80050065011, $80050056202,80050065021,80050065022,80050056231,80050056342,80050056222$, $80050056341,80050056331$.

Denver Southeast: 80310029013, 80310029023, 80310029022, 80310030011, 80310030012, 80310030014, 80310030013, 80310034021, 80310034023, 80310030021, 80310030032, 80310030042, 80310030041, 80310039023, 80310040052, 80310039022, 80310040051, 80310040061, 80310051042, 80310053001, 80310051024, 80310069014, 80050151001, 80310040033, 80310040031, 80310068123, 80050151002, 80310068121, 80310040041, 80310068092, 80310068091, 80310068102, 80310068101, 80050068541, 80310070062, 80310070061, 80050804004, 80050804002, 80050804003, 80050815001, 80050836001, 80310067011, 80310068041, 80050067121, 80050067122, 80050068582, 
80050068581, 80050068572, 80050067131, 80050067071, 80050067073, 80050068154, 80050067092, 80050068561, 80350141163, 80350140013, 80350141162, 80350140071.

Denver Five Points: 80310017015, 80310017022, 80310017021, 80310017014, 80310016002, 80310026012, 80310026011, 80310026021, 80310024032, 80310024022, 80310024033, 80310024021, 80310024031, 80310016003, 80310016001, 80310023003, $80310023002,80310023001,80310036013$.

Denver West: 80310016002, 80310011023, 80310017011, 80310017013, 80310017015, 80310017012, 80310006001, 80310019021, 80310019011, 80310008001, 80310007021, 80310007025, 80310007022, 80310007024, 80310007023, 80310009051, 80310009052, 80310009053, 80310009054, 80310007011, 80310007012, 80310007013, 80310009043, 80310009041, 80310009042, 80310009044, 80590114011, 80590114012, 80590114022, 80590114023, 80590115501, 80590115504, 80590115502, 80590115503, 80590115505, 80590110002, 80590110003, 80590110006, 80590111001, 80590111004, 80590111005, 80590111002, 80590111003, 80590158001, 80590158003, 80590109021, 80590109022, 80599800001, 80590109014, 80590109015, 80590117323, 80590117324, 80590117322, 80590117331, 80590117321, 80590117212, 80590101001, 80590100001, $80590098495,80590098492$.

Denver Airport: 80310017013, 80310017015, 80310019021, 80310017012, 80310017011, 80310011023, 80310016002, 80310016001, 80310036013, 80310036015, 80310036014, 80310036011, 80310035001, 80310035005, 80310035004, 80310036021, 
80310036022, 80310041011, 80310041071, 80310041061, 80010082003, 80010083901, 80310083882, 80319800001.

Salt Lake City Central: 490351001002, 490351008003, 490351008002, 490351008001, 490351011023, 490351011021, 490351025001, 490351021001, 490351023002, 490351140001, 490351029001, 490351023002, 490351030002, 490351028011, 490351028021, 490351029002, 490351029003, 490351032003, 490351114006, 490351115001, 490351116001, 490351116004, 490351117011, 490351116002, 490351119061, 490351119062, 490351120013, 490351121002, 490351120024, 490351122021, 490351122011, 490351122022, 490351122013, 490351122023, 490351123023, 490351124041.

Salt Lake City Sandy/Draper: 490351124041, 490351124042, 490351124021, 490351125032, 490351125034, 490351125033, 490351126101, 490351124022, 490351126103, 490351127003, 490351124024, 490351127002, 490351127004, 490351126054, 490351126053, 490351126051, 490351126052, 490351128124, 490351128172, 490351128221, 490351128222, 490351128043, 490351128232, 490351128231, 490351128233, 490351128052, 490351128053, 490351128161, $490351128151,490351128211$.

Salt Lake City South Jordan: 490351124031, 490351124032, 490351142001, 490351142002, 490351129143, 490351129182, 490351129171, 490351129202, 490351129212, 490351129172, 490351129213, 490351129162, 490351129161, 490351129163, 490351131013, 490351131022, 490351131021, 490351131012, 
490351131014, 490351130071, 490351131082, 490351152092, 490351152091, 490351130201.

Salt Lake City West Valley City: 490351115001, 490351028023, 490351133051, 490351133052, 490351133053, 490351133054, 490351133071, 490351133081, 490351133101, 490351133082, 490351133102, 490351133103, 490351133093, 490351133091.

Salt Lake City University: 490351140001, 490351023001, 490351021001, 490351023002, 490351019001, 490351019002, 490351020001, 490351020002, 490351017001, 490351017002, 490351017003, 490351018001, 490351018002, 490351018003, 490351015002, 490351015001, 490351015003, 490351015004, 490351016002, 490351016001, 490351016003, 490351148003, 490351014003, $490351014002,490351014001$.

Salt Lake City Airport: 490351001002, 490351008003, 490351008002, 490351008001, 490351011023, 490351011021, 490351025001, 490351021001, 490351023002, 490351140001, 490351025001, 490351006001, 490351006005, 490351026001, 490351006002, 490351006003, 490351006004, 490351027021, 490351003061, 490351003062, 490359800001.

Portland Central: 410510052002, 410510052001, 410510056002, 410510056001, 410510056004, 410510057002, 410510057003, 410510106002, 410510106001, 410510106003, 410510050001, 410510051002, 410510051003, 410510023031, 
410510023032, 410510024023, 410510021001, 410510024022, 410510020001, 410510025022, 410510025021, 410510025002 410510026003, 410510019004, 410510019003, 410510027012, 410510027013, 410510027021, 410510027022, 410510019001, 410510019002, 410510018022, 410510018021, 401510018013, 410510018012, 410510018011, 410510028023, 410510028022, 410510028021, 410510029024, 410510017017, 410510017016, 410510017015, 410510017013, 410510017012, 410510017011, 410510029023, 410510029034, 410510029033, 410510029032, 410510017021, 410510017022, 410510078002, 410510080011, 410510080012, 410510081003, 410510081004, 410510081002, 410510082011.

Portland Gresham: 410510017022, 410510017023, 410510016021, 410510081003, 410510081004, 410510081002, 410510082011, 410510082021, 410510081001, 410510082022, 410510093022, 410510093021, 410510092012, 410510092013, 410510092011, 410510092021, 410510092022, 410510093011, 410510093012, 410510093013, 410510097011, 410510097012, 410510096052, 410510096061, 410510097023, 410510096053, 410510096062, 410510097021, 410510097022, 410510096041, 410510096042, 410510098012, 410510096032, 410510098011, 410510101002, 410510101004, 410510100022, 410510100021, 410510101003, 410510100013, 410510099042, 410510099061, 410510099062, 410510100012, 410510104052, 410510104051, 410510104054, 410510100011, 410510099071, 410510099072, 410510104084, 410511014083, 410510104112, 410511014102. 
Portland Hillsboro: 410510057002, 410510106003, 410510051002, 410510106001, 410510106002, 410510056004, 410510056001, 410510056002, 410510055001, 410510055002, 410510052002, 410510052001, 410510050001, 410510049003, 410510049002, 410510048003, 410510048002, 410510047003, 410510052003, 410510052004, 410510046021, 410510046022, 410510046012, 410510069001, 410670301013, 410670302001, 410670302002, 410670302003, 410670313004, 410670313003, 410670313001, 410670313002, 410670304013, 410670311001, 410670311002, 410670312004, 410670312001, 410670312002, 410670314021, 410670314043, 410670314022, 410670316134, 410670316112, 410670316104, 410670316103, 410670316121, 410670316131, 410670316063, 410670316142, 410670316091, 410670316092, 410670316093, 410670316094, 410670324081, 410670326071, 410670324082, 410670326081, 410670324045, 410670324042, 410670326065, 410670324092, 410670324102, 410670324103, 410670324091, 410670326064, 410670326063, 410670326041, 410670326042, 410670325012, 410670325021, 410670325011, 410670326043, 410670326033, $410670326045,410670326044$.

Portland Clackamas: 410510081002, 410510017023, 410510016021, 410510016022, 410510082011, 410510082021, 410510082012, 410510082013, 410510016023, 410510083012, 410510083021, 410510083011, 410510083022, 410510006014, 410510006013, 410510006011, 410510006012, 410510085002, 410510006024, 410510006023, 410510006022, 410510006021, 410510089022, 410510089021, 410050216011, 410050216012, 410050216021, 410050222011, 
410050222012, 410050222013, 410050220171, 410050222061, 410050222062, $410050222051,410050221072$.

Portland Milwaukie: 410510050001, 410510052001, 410510052002, 410510055002, 410510055001, 410510051002, 410510106001, 410510106002, 410510056001, 410510056004, 410510056002, 410510056003, 410510058001, 410510058002, 410510060011, 410510057001, 410510057002, 410510057003, 410510057001, 410510059001, 410510011011, 410510011012, 410510011021, 410510057001, 410510012023, 410510012022, 410510010003, 410510010005, 410510010001, 410510010004, 410510010002, 410510009013, 410510009023, 410510003014, 410510003012, 410510002001, 410510002002, 410510001001, 410510001002, 410510001003, 410510001004, 410510002003, 410510002004, 410510003024, 410510003026, 410510003021, 410510003025, 410050209001, 410050209002, 410050208001, 410050208002, 410050211001, 410050208002, 410510063001, 410050212001, 410050212002, 410050212003, 410050214003, 410050214001, 410050214002, 410050213001, 410050213003, 410050213002.

Portland Interstate: 410510057003, 410510057002, 410510056002, 410510055002, 410510056001, 410510056004, 410510052002, 410510052001, 410510106002, 410510106001, 410510106003, 410510050001, 410510051002, 410510021001, 410510023032, 410510051003, 410510051001, 410510023031, 410519800001, 410510022034, 410510022031, 410510035022, 410510035021, 410510034023, 410510034022, 410510034013, 410510034014, 410510035014, 
410510035011, 410510035013, 410510035012, 410510039022, 410510038031, 410510038033, 410510038032, 410510037023, 410510037013, 410510038021, 410510038022, 410510038023, 410510039021, 410510039013, 401510039012, 410510039011, 410510038013, 410510038012, 410510038011, 410510037014, $410510072021,410510072012,410510072011$.

Portland Airport: 410510029031, 410510077002, 410510078002, 410510078001, 410510077001, 410510079002, 410510079001, 410510073001. 


\section{APPENDIX D: INTERVIEW QUESTIONS}

1. Describe the development of light rail in the (Denver/Salt Lake City/Portland) region, with particular attention to its successes and shortcomings along the way.

2. How have these successes or shortcomings been addressed from a service planning standpoint?

3. From your knowledge, which corridors have performed well and which have not performed as well?

4. What do you think about using ridership per mile, ridership growth, capital costs, and operating cost per mile and hour as metrics for performance? Is there anything missing from these measures?

5. I've found in my analysis that this is how corridors in your city scored relative to each other (list of each corridor and its performance score). Are these surprising or expected?

6. Should there be more nuance in interpreting these statistics?

7. What characteristics of a corridor do you see as most important for strong performance? Both neighborhood factors and transit factors.

8. I found headways and population density to be most relevant. Do these make sense, or is something missing?

9. What lessons do you believe have been learned from light rail development in (Denver/Salt Lake City/Portland) that could inform either expansions here or planning in other traditionally auto-dependent cities? 